\title{
10. PETROGRAPHY, MINERAL CHEMISTRY, AND PHASE RELATIONS OF THE BASEMENT BONINITE SERIES OF SITE 786, IZU-BONIN FOREARC ${ }^{1}$
}

\author{
Sieger R. van der Laan, ${ }^{2}$ R. J. Arculus, ${ }^{3}$ J. A. Pearce, ${ }^{4}$ and B. J. Murton ${ }^{5}$
}

\begin{abstract}
The $720 \mathrm{~m}$ of igneous basement that was penetrated at Site 786 of Ocean Drilling Program Leg 125 consists of boninite-series volcanics. Bronzite andesites dominate the lithology and primitive magmas of high-Ca, intermediate-Ca, and low-Ca boninite are present in subordinate amounts. Sparsely phyric boninites typically contain olivine and orthopyroxene phenocrysts with $\mathrm{Mg}$ numbers $[=\mathrm{Mg} /(\mathrm{Mg}+\mathrm{Fe})$ in moles] between $86 \%$ and $87 \%$. Their high whole-rock Mg numbers, and the absence of zonation in the phenocrysts, imply equilibration at temperatures probably between $1200^{\circ}$ and $1250^{\circ} \mathrm{C}$, and $20^{\circ}$ to $50^{\circ} \mathrm{C}$ below their liquidus. Equilibrium olivine and orthopyroxene have identical $\mathrm{Mg}$ numbers, and $\mathrm{Mg} / \mathrm{Fe}$ partitioning between these minerals and the melt thus can be described with a single $\mathrm{Kd}$. The invariably phenocryst-rich bronzite andesites contain plagioclase that has spectacular zoning and mafic phases that can be as magnesian as those of the boninite parent. The most evolved melts are rhyolites with hypersthene, plagioclase $\left(\mathrm{An}_{50}\right)$, and magnetite. Eruption temperatures for the rhyolites are estimated at about $1000^{\circ} \mathrm{C}$. Some magmas contain ferroactinolite in the groundmass, which is most likely a secondary, low-temperature phase.

The locally large contrasts in degree of alteration are consistent with multiple episodes of magmatic activity. However, all igneous events produced boninite volcanics. Only the first, the edifice-building episode, gave rise to differentiated magmas. Differentiation of parental boninites took place by limited fractional crystallization, producing bronzite andesites. The erupted andesites, dacites and rhyolites are filter pressed extracts from these bronzite andesite magmas, which, as a result, have accumulated crystals. Subsequent younger igneous events produced high-Ca and intermediate-Ca boninites which intruded as dikes and sills throughout the basement sequence. The mineralogy of the dikes and sills reflects variable degrees of subliquidus cooling of the magma before emplacement.
\end{abstract}

\section{INTRODUCTION}

Boninites have been widely recognized in forearc basement sequences in the Bonin-Marianas region of the western Pacific (Hussong, Uyeda, et al., 1981; Reagan and Meijer, 1984; Bloomer and Hawkins, 1987; Umino, 1986). Boninites vary in composition from high-Ca, low-Si types, to low-Ca, high-Si types and a continuum in primary melt compositions from basalt to low-Ca boninite is perceived to exist, based on petrological observations (Beccaluva and Serri, 1988) and analysis of phase equilibria during melting (van der Laan et al., 1989). Duncan and Green (1980) emphasized the secondstage melting hypothesis for the origin of boninites, concurring with the general notion that these magmas are derived from a mantle source that had undergone previous melting. Kuroda et al. (1978) proposed boninite as a possible calc-alkaline primary magma.

In each geographic occurrence, boninites are of a single distinct chemical character (summarized in Crawford et al., 1989); however, small amounts of higher-Ca types usually accompany low-Ca type boninites. Much attention has been focused on the petrology and phase chemistry of primitive boninites, but the boninite liquid line of descent and the evolved melt compositions have been less studied. Nevertheless, a continuous boninite differentiation series exists (Meijer, 1980) and was even recognized at the boninite type locality of Chichi-jima (Dobson, 1986; Umino, 1986). In a recent study, Kuroda et al., (1988) described the very late-stage differentiates, ferropigeonite quartz dacites, at this locality. Bloomer and Hawkins

'Fryer, P., Pearce, J. A., Stokking, L. B., et al., 1992. Proc. ODP, Sci. Results, 125: College Station, TX (Ocean Drilling Program).

${ }^{2}$ School of Ocean and Earth Sciences and Technology, University of Hawaii, Honolulu, HI 96822, U.S.A.

${ }^{3}$ Dept. of Geology and Geophysics, University of New England, Armidale, N.S.W. 2351. Australia.

${ }^{4}$ Dept. of Geological Sciences, University of Durham, Durham DH1 3LE, United Kingdom.

Institute of Oceanographic Sciences, Godalming, Surrey, GU8 5UB, United Kingdom.
(1987), who studied boninite series volcanic rocks from the Mariana inner trench wall, concluded that they were dissimilar to most other calc-alkaline series of island arcs.

Here, we describe the petrography of boninite series rocks of Site 786 in the Izu-Bonin forearc. We emphasize mineral assemblages and zonation patterns, and how they can be interpreted in terms of magmatic processes. Temperature and pressure constraints on these processes are derived by comparison with phase equilibria from experimental studies.

\section{General Procedure of Study}

A total of 187 thin sections from Site 786 was examined, of which 94 were taken aboard ship and 93 were prepared as part of this study. Of these, a subset of 40 was selected for further microanalytical study on the basis of petrography and bulk-rock geochemistry.

One of the aims of our petrographical study was to subdivide the lithology of Site 786 into cooling units; thus, special emphasis was placed on the recognition of lithological continuity between adjacent samples. Cooling units were named according to the core number and section in which they first appeared (e.g., Cooling Units 11R1, 35R2). When two new cooling units appeared in one core section, the second one had a suffix "a" appended to the name (e.g., Cooling Unit 11R1a). In the petrographical description section of this study, we will commonly refer to the cooling units. A detailed description of the petrography of each sample, including the cooling unit, is tabulated in the Appendix (in back pocket). Discrepancies with earlier shipboard descriptions are common, but those lacked the benefits of independent confirmation of mineralogy using the electron microprobe. All thin sections were examined several times to improve our determination of mineral relics in slightly and severely altered samples. For most samples, including those that are strongly altered, the original igneous mineralogy was emphasized in the petrographical descriptions. This was not possible with samples from the lowermost part of the hole which had undergone pervasive very-lowgrade metamorphism. The nature of the alteration products has not been studied by X-ray diffraction. 
When additional bulk-rock analyses subsequently became available, and samples were grouped by chemical type (Arculus et al., this volume), the internal consistency of the petrography for each chemical type confirmed the correctness of the petrographic determination. Chemical compositions may not concur with the petrography when thin section and sample for analysis were not obtained from the same piece of rock, as is common in the case of core-catcher samples (marked "CC").

\section{ANALYTICAL TECHNIQUES \\ Identification of Minerals with the Petrographic Microscope}

A concise description of the diagnostic criteria of the minerals and their alteration products seems appropriate in order to justify our identification and to aid future scholars with optical determination. Conoscopical study of optical properties was rarely necessary but was sometimes used to check 2-V angles of olivine, clinopyroxene, and amphibole. Modal percentages are visual estimates and have not been backed up with point counting. The phenocryst mineralogy is included in the lithological column of Hole 786B (Fig. 1).

\section{Olivine}

Olivine is rarely unaltered. It can be found as euhedral phenocrysts (Pl. IA) in glassy magnesian samples such as pillow rinds, and as round inclusions in orthopyroxene of $\mathrm{Mg}$ numbers $(\mathrm{Mg} \#)>85 \%$ (Pl. 1B). Fresh olivine is clear, colorless, and has a watery appearance. It has high birefringence and is distinct from clinopyroxene, which invariably has a touch of green or brown. The terminal faces of olivine often make a sharper angle than those of clinopyroxene, giving the phenocrysts a more pointed shape ( $\mathrm{Pl}$. 1A). Crystal faces are very well developed. Columnar crystals do not occur, and cleavage, characteristic of pyroxenes, is absent. Olivine commonly contains reddish $\mathrm{Cr}$-spinel inclusions that form the diagnostic criterion for the identification of olivine relics. $\mathrm{Cr}$-spinel was found only once as an inclusion in pyroxene. Olivine alters to carbonate with hematite, or to serpentine with talc and opaques. Relics of olivine are distinct from relics of pyroxene in shape and mineralogy (PI. 1C). Partially altered olivine is rare and was only found in one sample (125-786B-37R-1, 95-98 cm). Olivine or its relics can occur in aggregates, and rims of orthopyroxene are sometimes found as coronas around olivine (PI. ID).

\section{Orthopyroxene}

Orthopyroxene is present as phenocrysts and as acicular crystals in the groundmass. Phenocrysts are prismatic, columnar or lath-shaped and slightly brownish in plane-polarized light. Pleochroism is absent in enstatite but becomes noticeable in bronzite and compositions of $\mathrm{Mg} \#<80 \%$, and is strong in hypersthene. Pleochroic colors are apple-green to orangebrown. One cleavage direction is often apparent but orthopyroxene rarely exhibits the characteristic cross-hatched cleavage pattern. Birefringence in thin sections $30 \mathrm{~mm}$ thick is low for the magnesian end-members but can be first-order red to purple for iron-rich hypersthene. Orthopyroxene has parallel extinction and positive elongation. These characteristics, together with its high relief, form the diagnostic criteria for its presence in the groundmass where it is invariably acicular. Orthopyroxene alters to aggregates of monomineralic, faintly green serpentine. Partial alteration of phenocrysts is common. Orthopyroxene, generally of $\mathrm{Mg} \#<80 \%$, can occur in aggregates with plagioclase and/or augite, and, generally with $\mathrm{Mg \#}>80 \%$, it can be found as coronas around olivine relics.

\section{Clinopyroxene}

Clinopyroxenes of augite, pigeonite, and clinoenstatite were identified. All clinopyroxene phenocrysts are augites. Augite can also be found in the groundmass. Pigeonite and clinoenstatite are confined to the groundmass. Clinoenstatite was recognized only optically, and pigeonite only from microprobe analysis.

Augite is faintly greenish in plane-polarized light and does not exhibit pleochroism. It has high birefringence and oblique extinction. Phenocrysts are commonly prismatic and twinned, and one set of cleavage planes is usually prominent. Augite is the most alterationresistant mafic phase. It typically breaks down to a bright green birefringent product, similar to chlorite in appearance, and an opaque phase.

Pigeonite and augite could not be distinguished optically in the groundmass. Augite in the groundmass can be both equant and acicular. Equant augite is anhedral and stands out from the groundmass through its yellow-red birefringence. Euhedral, acicular augite or pigeonite is commonly twinned parallel to its length direction and has an extinction angle of about $45^{\circ}$. The easiest way to identify clinopyroxene in the groundmass is to observe (with crossed polars and $1-\lambda$ plate) its twin lamellae change in color (blue/pink) upon rotation through the $45^{\circ}$ position.

Clinoenstatite, in its characteristic appearance, has a columnar- to lath-shape, with lamellar twinning. The irregular twinning planes are parallel to the crystal length and fracturing is perpendicular to this direction (Pl. 1E). Clinoenstatite has low birefringence and oblique extinction. The presence of clinoenstatite was not confirmed by microprobe analysis.

Table 1. Representative olivine analyses.

\begin{tabular}{|c|c|c|c|c|c|c|c|c|c|c|c|c|c|c|}
\hline Sample & $\begin{array}{l}\text { Rock } \\
\text { type }\end{array}$ & $\mathrm{Na}_{2} \mathrm{O}$ & $\mathrm{MgO}$ & $\mathrm{Al}_{2} \mathrm{O}_{3}$ & $\mathrm{SiO}_{2}$ & $\mathrm{~K}_{2} \mathrm{O}$ & $\mathrm{CaO}$ & $\mathrm{TiO}_{2}$ & $\mathrm{Cr}_{2} \mathrm{O}_{3}$ & $\mathrm{MnO}$ & $\mathrm{FeO}$ & $\mathrm{NiO}$ & Total & $\mathrm{Mg} \#$ \\
\hline \multicolumn{15}{|l|}{ 125-786B- } \\
\hline $59 \mathrm{R}-3,84-91$ & LCB & 0.01 & 47.73 & 0.00 & 40.72 & 0.00 & 0.18 & 0.00 & 0.00 & 0.17 & 13.04 & 0.54 & 102.39 & 86.7 \\
\hline \multicolumn{15}{|l|}{$125-786 \mathrm{~A}-$} \\
\hline 13X-CC, $27-29$ & ICB & 0.01 & 49.85 & 0.04 & 40.62 & 0.05 & 0.27 & 0.00 & 0.00 & 0.29 & 9.65 & 0.14 & 100.91 & 90.2 \\
\hline $13 \mathrm{X}-\mathrm{CC}, 27-29$ & ICB & 0.00 & 49.57 & 0.00 & 40.58 & 0.00 & 0.27 & 0.00 & 0.00 & 0.16 & 10.10 & 0.46 & 101.14 & 89.7 \\
\hline 13X-CC, $27-29$ & ICB & 0.01 & 47.17 & 0.00 & 40.36 & 0.00 & 0.17 & 0.00 & 0.00 & 0.24 & 13.03 & 0.16 & 101.13 & 86.6 \\
\hline \multicolumn{15}{|l|}{ 125-786B- } \\
\hline 37R-1, 95-98 & ICB & 0.02 & 47.36 & 0.02 & 40.16 & 0.00 & 0.19 & 0.00 & 0.00 & 0.26 & 13.09 & 0.20 & 101.30 & 86.6 \\
\hline $37 \mathrm{R}-1,95-98$ & ICB & 0.03 & 47.68 & 0.03 & 40.22 & 0.00 & 0.17 & 0.00 & 0.13 & 0.20 & 12.56 & 0.40 & 101.40 & 87.1 \\
\hline $37 \mathrm{R}-3,31-35$ & ICB & 0.02 & 47.10 & 0.01 & 40.12 & 0.00 & 0.20 & 0.00 & 0.00 & 0.22 & 12.21 & 0.00 & 99.88 & 87.3 \\
\hline $37 \mathrm{R}-3,31-35$ & ICB & 0.02 & 46.35 & 0.01 & 40.15 & 0.00 & 0.20 & 0.00 & 0.24 & 0.00 & 13.16 & 0.36 & 100.48 & 86.3 \\
\hline $37 R-3,31-35$ & ICB & 0.02 & 46.54 & 0.01 & 40.33 & 0.00 & 0.21 & 0.00 & 0.00 & 0.41 & 13.50 & 0.26 & 101.27 & 86.0 \\
\hline
\end{tabular}

${ }^{\mathrm{a}} \mathrm{LCB}=$ low-Ca boninite and $\mathrm{ICB}=$ intermediate-Ca boninite. 


\section{Plagioclase}

Plagioclase is colorless and has low relief and low birefringence. Phenocrysts commonly have lamellar twins and complex zoning patterns, reflecting the morphology during stages of growth and resorption. Through extreme resorption, plagioclase and its aggregates can assume a "ball"-like shape (Pl. IF).

Plagioclase in the groundmass has a columnar to acicular shape and stands out because of its low relief. It has almost parallel extinction and negative elongation. With crossed polars and $1-\lambda$ plate, it appears yellow in the $45^{\circ}$ position. In this way it is easily recognized in especially trachytic groundmass textures.

\section{Spinel}

Spinel of Cr-spinel and magnetite composition was identified. $\mathrm{Cr}$-spinel may be euhedral to anhedral and is isotropic with a red to dark red color in plane-polarized light. Magnetite can be euhedral to anhedral and is commonly found as an opaque phase in the groundmass or as phenocrysts in evolved rocks.

\section{Amphibole}

Amphibole was identified in the groundmass of some samples as greenish laths with opaque specks on the surface. Its extinction angle is small and elongation positive; it can have lamellar twinning parallel to its length. The presence of groundmass amphibole was confirmed by microprobe in one sample. Amphibole also was found in a thin section of a microdiorite. In this sample, the large subhedral columnar crystals show pale green and yellow-green pleochroic colors and have a prominent cleavage parallel to the crystal length. Some have lamellar intergrowth and do not show complete extinction. The extinction angle of amphibole is small, its elongation positive, and its optical sign negative with $2 \mathrm{~V}_{\alpha}=65^{\circ}-70^{\circ}$.

\section{Electron Microprobe Analysis}

Polished and carbon-coated thin sections were analyzed using a JEOL 733 Superprobe. To obtain large numbers of analyses, we reduced the acquisition time by simultaneously using five wavelength spectrometers (WDS) at fixed positions to analyze for the elements $\mathrm{Na}, \mathrm{Mg}, \mathrm{Al}, \mathrm{Ca}$ and $\mathrm{Fe}$, and energy dispersive spectroscopy (EDS) for $\mathrm{Si}, \mathrm{K}, \mathrm{Ti}, \mathrm{Cr}, \mathrm{Ni}$, and $\mathrm{Mn}$. The background for the WDS elements was only measured at the beginning and end of each series of analyses of a single mineral type. A modified ZAF correction was applied to the data (Armstrong, 1988). Approximately 3000 analyses were collected in two sessions of one week each. Selected mineral analyses are presented for olivine (Table 1), orthopyroxene (Table 2), clinopyroxene (Table 3), plagioclase (Table 4), glass, and spinel and amphibole (Table 5). Zoning patterns were examined in detail and were analyzed along line profiles using automated step distances.

For all mafic minerals, glasses, and bulk-rock compositions, $\mathrm{Mg}$ numbers were calculated as the molar percentage of $\mathrm{Mg} /(\mathrm{Mg}+\mathrm{Fe})$. Because pyroxenes and olivine are poor in $\mathrm{Fe}^{3+}$, the $\mathrm{Mg}$ number will closely correspond to $\mathrm{Mg} /\left(\mathrm{Mg}+\mathrm{Fe}^{2+}\right)$, but for glasses and bulk rock it represents $\mathrm{Mg} /\left(\mathrm{Mg}+\mathrm{Fe}^{2+}+\mathrm{Fe}^{3+}\right)$. We decided to present pyroxene compositions in the pyroxene quadrilateral as well as the spatial zonation patterns of $\mathrm{Mg}$ number vs. distance.

Anorthite numbers (An\#) were calculated for plagioclase, glass, and bulk rock as the mole percentage of $\mathrm{Ca} /(\mathrm{Ca}+\mathrm{Na}+\mathrm{K})$. Because potassium contents are always low, these are similar to $\mathrm{Ca} /(\mathrm{Ca}+\mathrm{Na})$. For plagioclase, potassium contents are negligible and zonation patterns of anorthite content (An\%) vs. distance are presented. In all zoning profiles, the crystal rim is at distance zero. Note that relative crystal orientation at the exposed surface will cause stretching of analyzed profiles with respect to a cross section perpendicular to the growth direction. In addition, the crystal core does not need necessarily to be included in all exposed cross sections.

\section{STRATIGRAPHY AND AGE RELATIONS OF THE BASEMENT SEQUENCE}

Adetailed description of the lithostratigraphy and the age relationships among the cooling units, based on $\mathrm{K}-\mathrm{Ar}$ dating, formed the subject of contributions by Arculus et al. and Mitchell et al. (both this volume). Their findings are briefly summarized here.

The $720 \mathrm{~m}$ of igneous basement (Fig. 1) is a $40-$ to $42-\mathrm{Ma}$ volcanic construct with low-Ca bronzite andesite intrusives at the base, overlain by a cogenetic sequence of low-Ca boninites and bronzite andesite pillows. This basal sequence is cut by rhyolite dikes and is overlain by a series of predominantly intermediate-Ca bronzite andesite and andesite flows, with minor dacite and rhyolite flows, all of similar age ( 40 to $42 \mathrm{Ma}$ ). In a second, minor phase of igneous activity at about 34 to $35 \mathrm{Ma}$, intermediate-Ca and high-Ca boninite dikes and sills were emplaced throughout the sequence. A third intrusive event, postulated at about $17 \mathrm{Ma}$, is more speculative. It is thought to have produced the high- $\mathrm{Ca}$, intermediate- $\mathrm{Ca}$, and low-Ca boninites sills and dikes at the top of the sequence of Hole $786 \mathrm{~B}$, and those of Hole 786A. Thus all three episodes are characterized by boninite magmatic activity, but only the first episode gave rise to evolved magma compositions.

\section{PETROGRAPHY AND MINERAL COMPOSITIONS}

\section{Textures and Structures}

Hyaloclastites are common throughout the sequence indicating that many of the cooling units experienced contact with water and were erupted in a submarine environment. The location of hyaloclastites is marked in the lithologic column (Fig. 1). Their petrography of is not always described in the Appendix (in back pocket). Further evidence for submarine eruption is provided by the lava pillows that were recognized in Core 125-786B-16R and the Sections 125-786B$57 R-1$ through $-59 R-3$. From the extreme contrasts in alteration, the presence of dikes was inferred in Cores 125-786B-65R and -67R. Mingled magma in Section 125-786B-5R-2, and flow banding in boninite glass in Section 125-786B-17X-CC are evident.

\section{Boninite}

The samples that we have called boninites are all primitive and generally have $\mathrm{Mg}$ numbers above $68 \%$. Their silica contents and $\mathrm{Mg}$ numbers both show a negative correlation with $\mathrm{CaO}$, and the silica contents are distinctly higher than in basalt for equivalent Mg numbers. Three types of boninites are distinguished based on major-element chemistry. These are low-Ca boninite (LCB), intermediate-Ca boninite (ICB), and high-Ca boninite (HCB) (Arculus et al., this volume). The chemical distinctions are summarized in Table 6. Differences in petrography between the three boninite types are explained in this section. The bronzite andesites are likely to be related to the equivalent-Ca boninites and fall into two groups: low-Cabronzite andesite (LCBrzA) and intermediate-Ca bronzite andesite (ICBrzA). The ICBrzAs are the subject of the next section but because of their close spatial association, the LCBrzAs will be described with the LCBs.

Mineral and glass compositions are presented in Tables 1 to 5 and in Figures 2 to 6 . A detailed description of the boninites follows below.

\section{Low-Ca Boninite and Bronzite Andesite}

Low-Ca boninites and bronzite andesites are restricted to the lowermost part of the sequence (Core 125-786B-56R to $-62 \mathrm{R}$ and Cores $125-786 \mathrm{~B}-68 \mathrm{R}$ to $-72 \mathrm{R}$ ). The LCBs are locally interspersed with the LCBrzA pillow lavas. The strongly altered samples of 


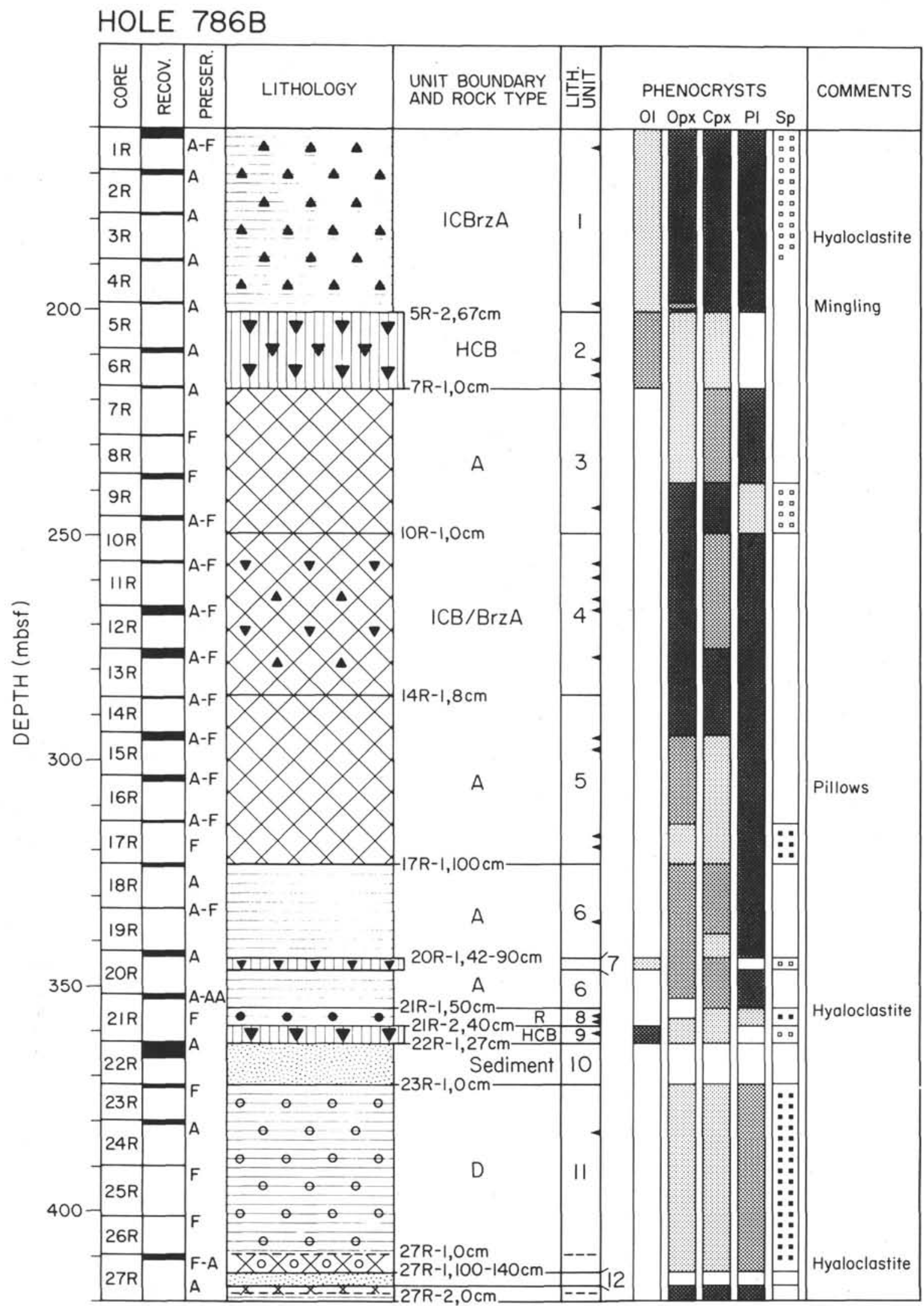

Figure 1. Lithostratigraphic column of Hole 786B. Abbreviations for preservation are as follows: $A A=$ very altered: groundmass and phenocrysts are pervasively altered, only phenocryst traces remaining. $\mathrm{A}=$ altered: groundmass and olivines altered, other phenocrysts largely fresh, some fresh glass. $\mathrm{F}=$ fresh: some alteration of groundmass and phenocrysts, olivine altered. $\mathrm{FF}=$ very fresh: no signs of alteration, vesicles may contain secondary mineralization. 


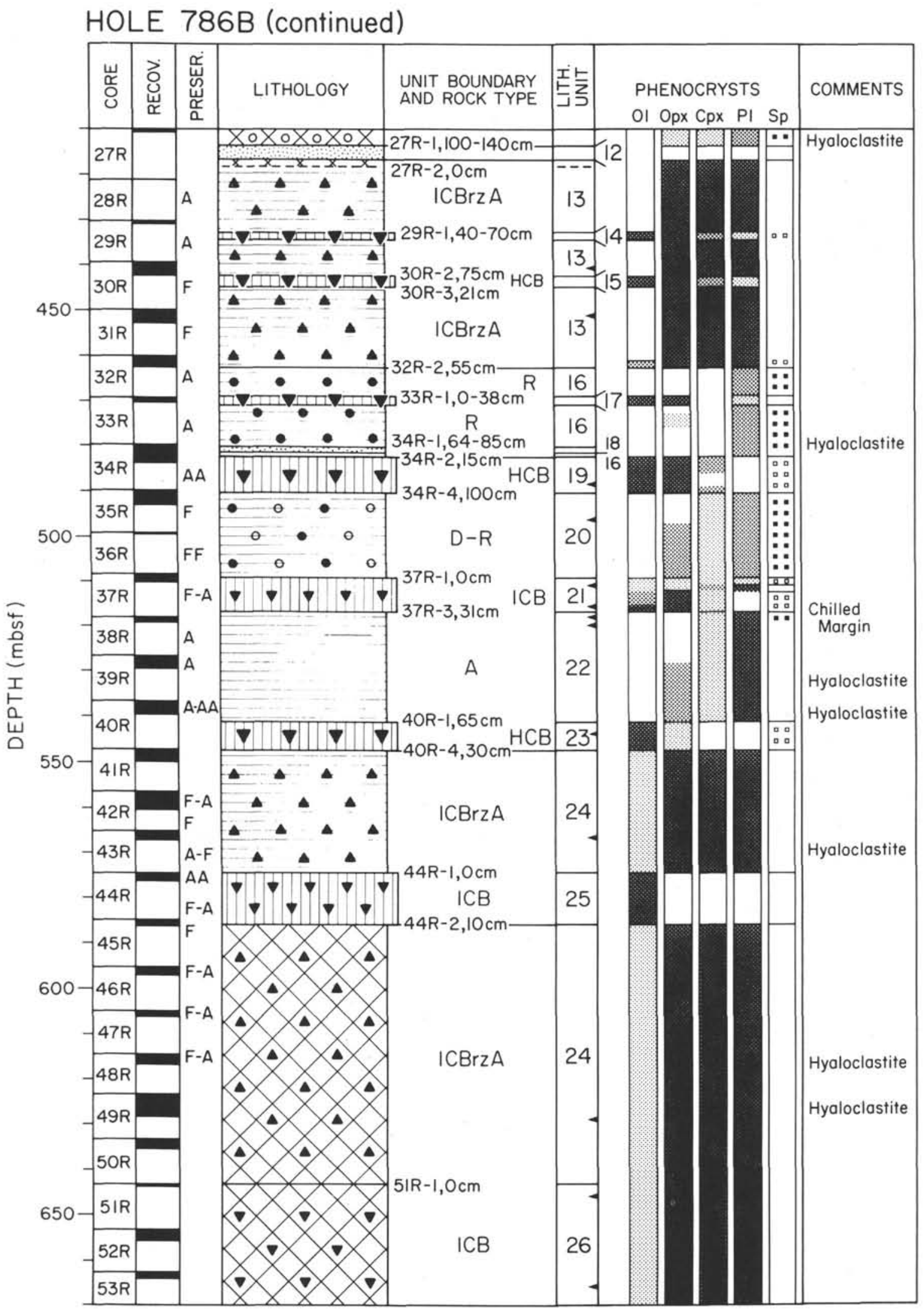

Figure 1 (continued). 


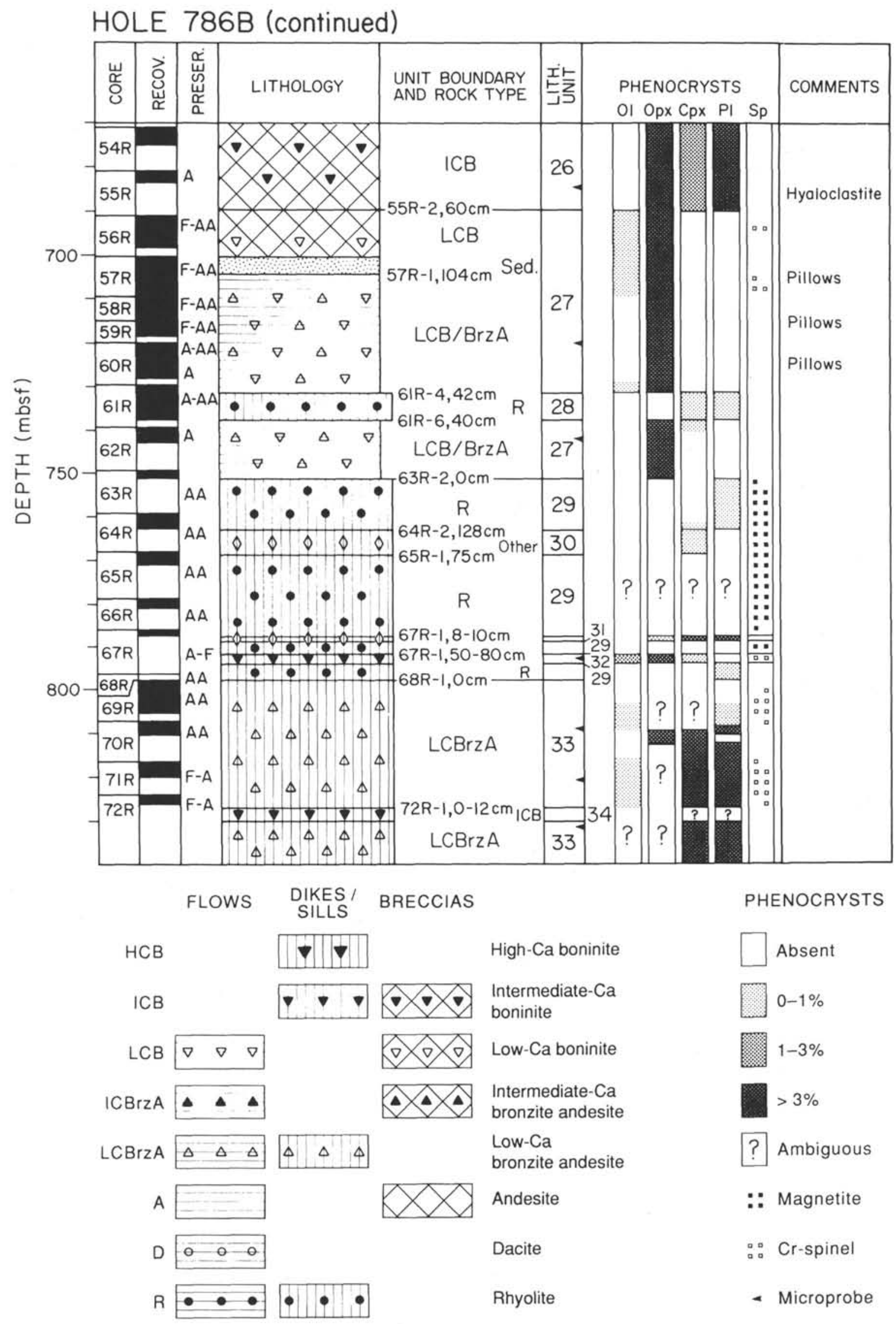

Figure 1 (continued). 
Table 2. Representative orthopyroxene analyses.

\begin{tabular}{|c|c|c|c|c|c|c|c|c|c|c|c|c|c|c|c|}
\hline Sample & $\begin{array}{l}\text { Rock } \\
\text { type }\end{array}$ & $\mathrm{Na}_{2} \mathrm{O}$ & $\mathrm{MgO}$ & $\mathrm{Al}_{2} \mathrm{O}_{3}$ & $\mathrm{SiO}_{2}$ & $\mathrm{~K}_{2} \mathrm{O}$ & $\mathrm{CaO}$ & $\mathrm{TiO}_{2}$ & $\mathrm{Cr}_{2} \mathrm{O}_{3}$ & $\mathrm{MnO}$ & $\mathrm{FeO}$ & $\mathrm{NiO}$ & Total & $\mathrm{Mg \#}$ & Wo\% \\
\hline \multicolumn{16}{|l|}{ 125-786B- } \\
\hline $59 \mathrm{R}-3,84-91$ & LCB & 0.02 & 28.66 & 1.84 & 54.88 & 0.00 & 1.37 & 0.07 & 0.33 & 0.29 & 13.92 & 0.00 & 101.38 & 78.6 & 2.6 \\
\hline 59R-3, 84-91 & LCB & 0.03 & 33.29 & 0.79 & 57.11 & 0.05 & 1.49 & 0.12 & 0.51 & 0.25 & 7.99 & 0.00 & 101.62 & 88.1 & 2.8 \\
\hline $62 \mathrm{R}-3,40-42$ & LCB & 0.05 & 32.34 & 0.98 & 56.50 & 0.00 & 1.57 & 0.00 & 0.52 & 0.12 & 8.36 & 0.00 & 100.40 & 87.3 & 3.0 \\
\hline \multicolumn{16}{|l|}{$125-786 \mathrm{~A}-$} \\
\hline I3X-CC, 27-29 & ICB & 0.03 & 31.74 & 1.54 & 55.27 & 0.00 & 1.83 & 0.14 & 0.36 & 0.23 & 8.52 & 0.38 & 100.03 & 86.9 & 3.5 \\
\hline $13 \mathrm{X}-\mathrm{CC}, 27-29$ & ICB & 0.02 & 30.97 & 1.98 & 55.72 & 0.00 & 2.05 & 0.09 & 0.30 & 0.21 & 9.70 & 0.43 & 101.46 & 85.1 & 3.9 \\
\hline \multicolumn{16}{|l|}{ 125-786B- } \\
\hline IIR-1, 122-126 & ICB & 0.15 & 26.87 & 1.31 & 56.04 & 0.08 & 1.59 & 0.12 & 0.20 & 0.15 & 15.56 & 0.00 & 102.08 & 75.5 & 3.1 \\
\hline $11 R-1,122-126$ & ICB & 0.10 & 32.98 & 0.58 & 57.71 & 0.00 & 1.25 & 0.15 & 0.43 & 0.19 & 8.49 & 0.00 & 101.88 & 87.4 & 2.3 \\
\hline $12 \mathrm{R}-2,14-16$ & ICB & 0.11 & 34.27 & 0.55 & 57.48 & 0.00 & 1.22 & 0.00 & 0.38 & 0.00 & 7.05 & 0.00 & 101.06 & 89.7 & 2.2 \\
\hline $12 \mathrm{R}-2,14-16$ & ICB & 0.13 & 28.18 & 1.02 & 55.40 & 0.08 & 1.61 & 0.00 & 0.00 & 0.34 & 14.79 & 0.24 & 101.78 & 77.3 & 3.1 \\
\hline $37 \mathrm{R}-1,95-98$ & ICB & 0.03 & 31.61 & 1.54 & 56.03 & 0.00 & 1.91 & 0.11 & 0.50 & 0.15 & 9.07 & 0.16 & 101.10 & 86.1 & 3.6 \\
\hline $51 \mathrm{R}-1,51-55$ & ICB & 0.03 & 31.16 & 0.81 & 56.22 & 0.00 & 2.04 & 0.00 & 0.22 & 0.22 & 10.21 & 0.28 & 101.19 & 84.5 & 3.8 \\
\hline $51 \mathrm{R}-1,51-55$ & ICB & 0.03 & 26.12 & 0.65 & 55.08 & 0.00 & 1.50 & 0.00 & 0.24 & 0.28 & 17.54 & 0.00 & 101.45 & 72.6 & 2.9 \\
\hline $53 R-2,12-14$ & ICB & 0.03 & 25.70 & 0.93 & 54.16 & 0.00 & 1.45 & 0.18 & 0.07 & 0.38 & 18.38 & 0.00 & 101.28 & 71.4 & 2.8 \\
\hline $53 R-2,12-14$ & ICB & 0.03 & 32.12 & 0.74 & 56.72 & 0.00 & 1.59 & 0.13 & 0.53 & 0.20 & 9.06 & 0.00 & 101.13 & 86.3 & 3.0 \\
\hline $55 \mathrm{R}-1.115-118$ & ICB & 0.01 & 32.36 & 0.72 & 56.43 & 0.00 & 2.02 & 0.00 & 0.41 & 0.25 & 8.30 & 0.33 & 100.84 & 87.4 & 3.8 \\
\hline $55 \mathrm{R}-1,115-118$ & ICB & 0.02 & 28.48 & 1.12 & 54.85 & 0.00 & 1.74 & 0.00 & 0.70 & 0.30 & 13.78 & 0.00 & 100.98 & 78.7 & 3.3 \\
\hline $67 R-1,62-63$ & ICB & 0.04 & 31.78 & 1.76 & 55.86 & 0.00 & 2.00 & 0.07 & 0.38 & 0.15 & 8.76 & 0.23 & 101.02 & 86.6 & 3.8 \\
\hline $6 R-2,137-138$ & HCB & 0.09 & 27.31 & 2.13 & 54.02 & 0.00 & 1.52 & 0.16 & 0.00 & 0.41 & 15.63 & 0.00 & 101.27 & 75.7 & 2.9 \\
\hline $6 \mathrm{R}-2,137-138$ & HCB & 0.08 & 29.39 & 1.66 & 55.31 & 0.00 & 1.44 & 0.09 & 0.00 & 0.31 & 13.14 & 0.00 & 101.42 & 79.9 & 2.7 \\
\hline $6 \mathrm{R}-3,17-22$ & HCB & 0.02 & 29.77 & 1.00 & 55.52 & 0.00 & 2.08 & 0.13 & 0.14 & 0.33 & 12.19 & 0.00 & 101.18 & 81.3 & 3.9 \\
\hline $34 \mathrm{R}-4,14-21$ & HCB & 0.03 & 32.27 & 0.50 & 56.62 & 0.00 & 1.86 & 0.14 & 0.25 & 0.26 & 8.51 & 0.00 & 100.40 & 87.1 & 3.5 \\
\hline $34 \mathrm{R}-4,14-21$ & $\mathrm{HCB}$ & 0.03 & 31.07 & 1.18 & 56.23 & 0.00 & 1.95 & 0.14 & 0.32 & 0.26 & 9.59 & 0.00 & 100.80 & 85.2 & 3.7 \\
\hline $40 \mathrm{R}-2,54-56$ & HCB & 0.03 & 30.86 & 1.39 & 55.74 & 0.00 & 1.56 & 0.00 & 0.12 & 0.34 & 10.65 & 0.00 & 100.70 & 83.8 & 3.0 \\
\hline 1R-1, 75-79 & ICBrzA & 0.09 & 31.95 & 0.62 & 55.72 & 0.00 & 1.89 & 0.00 & 0.48 & 0.24 & 9.60 & 0.22 & 100.79 & 85.6 & 3.5 \\
\hline $1 \mathrm{R}-1,75-79$ & ICBrzA & 0.08 & 26.53 & 1.00 & 54.86 & 0.00 & 1.62 & 0.20 & 0.13 & 0.46 & 17.09 & 0.00 & 101.97 & 73.5 & 3.1 \\
\hline $9 \mathrm{R}-1,113-118$ & ICBrzA & 0.03 & 29.49 & 1.06 & 56.02 & 0.00 & 1.83 & 0.00 & 0.19 & 0.37 & 12.45 & 0.00 & 101.43 & 80.9 & 3.5 \\
\hline $12 \mathrm{R}-2,120-124$ & ICBrzA & 0.04 & 32.10 & 0.73 & 56.73 & 0.00 & 1.76 & 0.00 & 0.32 & 0.21 & 9.14 & 0.21 & 101.25 & 86.2 & 3.3 \\
\hline $12 \mathrm{R}-2,120-124$ & ICBrzA & 0.03 & 28.55 & 0.84 & 55.55 & 0.00 & 1.60 & 0.11 & 0.24 & 0.22 & 14.01 & 0.00 & 101.15 & 78.4 & 3.1 \\
\hline $13 \mathrm{R}-1,34-36$ & ICBrzA & 0.08 & 33.58 & 0.54 & 57.21 & 0.00 & 0.96 & 0.00 & 0.34 & 0.51 & 8.48 & 0.00 & 101.71 & 87.6 & 1.8 \\
\hline $13 \mathrm{R}-1,34-36$ & ICBrzA & 0.09 & 26.44 & 0.97 & 54.80 & 0.11 & 1.44 & 0.00 & 0.00 & 0.42 & 16.94 & 0.00 & 101.20 & 73.6 & 2.8 \\
\hline $30 \mathrm{R}-1,29-31$ & ICBrzA & 0.02 & 27.77 & 0.97 & 55.04 & 0.00 & 1.43 & 0.00 & 0.12 & 0.18 & 15.31 & 0.17 & 101.00 & 76.4 & 2.7 \\
\hline $30 \mathrm{R}-1,29-31$ & ICBrzA & 0.03 & 29.25 & 1.03 & 55.38 & 0.00 & 1.60 & 0.17 & 0.00 & 0.32 & 13.22 & 0.00 & 101.00 & 79.8 & 3.0 \\
\hline $31 \mathrm{R}-2,86-87$ & ICBrzA & 0.03 & 33.48 & 0.40 & 57.17 & 0.00 & 1.23 & 0.00 & 0.41 & 0.30 & 8.06 & 0.13 & 101.20 & 88.1 & 2.3 \\
\hline $31 \mathrm{R}-2,86-87$ & ICBrzA & 0.02 & 26.43 & 1.28 & 53.96 & 0.00 & 2.09 & 0.00 & 0.30 & 0.45 & 16.19 & 0.00 & 100.70 & 74.4 & 4.1 \\
\hline $43 \mathrm{R}-2,43-52$ & ICBrzA & 0.04 & 32.65 & 0.71 & 57.34 & 0.00 & 1.40 & 0.00 & 0.42 & 0.35 & 8.75 & 0.00 & 101.66 & 86.9 & 2.6 \\
\hline $43 \mathrm{R}-2,43-52$ & ICBrzA & 0.04 & 28.56 & 1.27 & 55.40 & 0.00 & 1.30 & 0.00 & 0.26 & 0.26 & 14.06 & 0.00 & 101.15 & 78.4 & 2.5 \\
\hline $49 \mathrm{R}-4,32-37$ & ICBrzA & 0.09 & 25.93 & 0.91 & 54.34 & 0.00 & 1.84 & 0.00 & 0.21 & 0.60 & 17.69 & 0.27 & 101.88 & 72.3 & 3.6 \\
\hline $49 \mathrm{R}-4,32-37$ & ICBrzA & 0.09 & 27.98 & 1.24 & 55.20 & 0.00 & 1.39 & 0.00 & 0.11 & 0.30 & 15.46 & 0.20 & 101.96 & 76.3 & 2.7 \\
\hline $17 \mathrm{R}-1,67-69$ & A & 0.09 & 26.38 & 0.89 & 54.64 & 0.00 & 1.96 & 0.12 & 0.00 & 0.32 & 16.63 & 0.00 & 101.03 & 73.9 & 3.8 \\
\hline $17 \mathrm{R}-1,81-83$ & A & 0.10 & 23.74 & 0.87 & 54.48 & 0.00 & 1.72 & 0.00 & 0.00 & 0.59 & 20.69 & 0.00 & 102.18 & 67.2 & 3.4 \\
\hline $17 \mathrm{R}-1,81-83$ & A & 0.08 & 30.97 & 0.88 & 56.93 & 0.00 & 2.00 & 0.00 & 0.45 & 0.24 & 10.29 & 0.00 & 101.84 & 84.3 & 3.8 \\
\hline $15 R-2,3-8$ & A & 0.03 & 21.71 & 0.95 & 52.96 & 0.00 & 1.74 & 0.10 & 0.00 & 0.47 & 22.89 & 0.22 & 101.08 & 62.8 & 3.5 \\
\hline $15 R-2,3-8$ & A & 0.02 & 25.17 & 0.97 & 53.84 & 0.00 & 1.65 & 0.16 & 0.00 & 0.44 & 18.85 & 0.00 & 101.11 & 70.4 & 3.2 \\
\hline 19R-1,91-94 & A & 0.12 & 23.12 & 1.01 & 54.15 & 0.00 & 3.96 & 0.10 & 0.00 & 0.36 & 18.65 & 0.00 & 101.48 & 68.8 & 7.8 \\
\hline 19R-1, 91-94 & A & 0.14 & 21.47 & 1.01 & 53.30 & 0.00 & 4.70 & 0.00 & 0.00 & 0.61 & 19.87 & 0.00 & 101.11 & 65.8 & 9.4 \\
\hline $24 \mathrm{R}-2,5-9$ & D & 0.02 & 24.12 & 1.08 & 53.08 & 0.00 & 1.50 & 0.11 & 0.00 & 0.41 & 20.25 & 0.00 & 100.56 & 68.0 & 2.9 \\
\hline $21 \mathrm{R}-1,129-132$ & $\mathrm{R}$ & 0,02 & 18.03 & 0.48 & 52.32 & 0.00 & 1.49 & 0.11 & 0.00 & 0.62 & 27.81 & 0.00 & 100.86 & 53.6 & 3.1 \\
\hline $21 \mathrm{R}-1,129-132$ & $\mathrm{R}$ & 0.05 & 16.23 & 0.67 & 51.61 & 0.00 & 1.50 & 0.14 & 0.00 & 0.88 & 28.89 & 0.00 & 99.96 & 50.0 & 3.2 \\
\hline $21 \mathrm{R}-2,28-32$ & $\mathrm{R}$ & 0.02 & 16.50 & 0.83 & 51.07 & 0.00 & 1.67 & 0.18 & 0.00 & 0.93 & 30.20 & 0.00 & 101.39 & 49.3 & 3.5 \\
\hline $21 \mathrm{R}-2,28-32$ & $\mathrm{R}$ & 0.03 & 18.11 & 0.69 & 52.03 & 0.00 & 1.52 & 0.14 & 0.00 & 0.71 & 28.21 & 0.26 & 101.70 & 53.4 & 3.1 \\
\hline
\end{tabular}

Notes: $\mathrm{Wo} \%=\mathrm{Ca} /(\mathrm{Ca}+\mathrm{Mg}+\mathrm{Fe}) ; \mathrm{En} \%=\mathrm{Mg} /(\mathrm{Ca}+\mathrm{Mg}+\mathrm{Fe}) ; \mathrm{Fs} \%=\mathrm{Fe} /(\mathrm{Ca}+\mathrm{Mg}+\mathrm{Fe})$, all in mol\%

${ }^{\mathrm{L}} \mathrm{LCB}=$ low-Ca boninite, $\mathrm{ICB}=$ intermediate-Ca boninite, $\mathrm{HCB}=$ high-Ca boninite, $\mathrm{ICBrzA}=$ intermediate-Ca bronzite andesite, $\mathrm{A}=$ andesite, $\mathrm{D}=$ dacite, and $\mathrm{R}=$ rhyolite

Cooling Unit 57R5 are thought to be LCBs. Mineral compositions of two samples (125-786B-59R-3, 84-91 cm, and -62R-3, 40-42 cm) are presented in Table 1 and 2, with zoning patterns in Figure 2.

None of the LCB-classified samples from Hole $786 \mathrm{~A}$ resemble boninite, as they are too magnesian. Their analyses were obtained on multiple core-catcher fragments and need not correspond to the thin-section petrography. It is therefore unclear whether the youngest igneous event did indeed produce low-Ca boninite melt compositions.

Most LCB samples have modal phenocryst contents of $2 \%$ to $5 \%$. Olivine phenocrysts are invariably altered, enstatite is generally unaltered, and a few samples have traces of augite. Olivine relics contain $\mathrm{Cr}$-spinel inclusions. Small, rounded olivine inclusions can be found in enstatite (PI. 1B). One such inclusion, analyzed from Sample 125-786B-59R-3, 84-91 cm, contained $86.7 \%$ forsterite. Olivine and orthopyroxene have almost identical $\mathrm{Mg}$ numbers in this sample, but bronzite with a $\mathrm{Mg} \#=79 \%$ shows evidence of resorption.

The groundmass of the LCBs was originally glassy but is now largely altered and contains variable amounts of clinopyroxene with or without orthopyroxene. Clinoenstatite might be present in the groundmass of Section 125-786B-57R-5 samples in which also some spinifex pyroxene was observed (Pl. 1E). Magnetite is invariably absent from the groundmass.

Samples from Section 125-786B-68R-1 to -72R-1 are thought to be LCBrzA but no bronzite remained unaltered. All LCBrzAs are crystalrich and contain $20 \%$ to $30 \%$ phenocrysts. About half contain a trace to $1 \%$ olivine relics with $\mathrm{Cr}$-spinel inclusions and commonly with relics of orthopyroxene coronas. Augite and plagioclase analyses are presented in Tables 3 and 4, and zoning profiles in Figure 2. While the LCBs are 
Table 2 (continued).

\begin{tabular}{|c|c|c|c|}
\hline Sample & En\% & Fs\% & \\
\hline \multicolumn{4}{|l|}{$125-786 \mathrm{~B}-$} \\
\hline $59 \mathrm{R}-3,84-91$ & 76.5 & 20.9 & \\
\hline 59R-3, 84-91 & 85.7 & 11.5 & \\
\hline $62 \mathrm{R}-3,40-42$ & 84.8 & 12.3 & \\
\hline \multicolumn{4}{|l|}{$125-786 \mathrm{~A}$ - } \\
\hline 13X-CC, 27-29 & 83.9 & 12.6 & \\
\hline $13 \mathrm{X}-\mathrm{CC}, 27-29$ & 81.7 & 14.4 & \\
\hline \multicolumn{4}{|l|}{$125-786 \mathrm{~B}-$} \\
\hline 11R-1, 122-126 & 73.1 & 23.8 & \\
\hline $11 \mathrm{R}-1,122-126$ & 85.3 & 12.3 & \\
\hline $12 \mathrm{R}-2,14-16$ & 87.6 & 10.1 & jacket \\
\hline $12 R-2,14-16$ & 74.9 & 22.0 & \\
\hline $37 R-1,95-98$ & 83.0 & 13.4 & \\
\hline $51 \mathrm{R}-1,51-55$ & 81.2 & 14.9 & \\
\hline $51 \mathrm{R}-1,51-55$ & 70.5 & 26.6 & \\
\hline $53 \mathrm{R}-2,12-14$ & 69.4 & 27.8 & \\
\hline $53 R-2,12-14$ & 83.8 & 13.3 & \\
\hline $55 \mathrm{R}-1,115-118$ & 84.1 & 12.1 & \\
\hline $55 \mathrm{R}-1,115-118$ & 76.0 & 20.6 & \\
\hline $67 R-1,62-63$ & 83.3 & 12.9 & \\
\hline $6 R-2,137-138$ & 73.5 & 23.6 & \\
\hline $6 \mathrm{R}-2,137-138$ & 77.8 & 19.5 & \\
\hline $6 \mathrm{R}-3,17-22$ & 78.1 & 17.9 & \\
\hline $34 \mathrm{R}-4,14-21$ & 84.1 & 12.4 & \\
\hline $34 R-4,14-21$ & 82.1 & 14.2 & \\
\hline $40 \mathrm{R}-2,54-56$ & 81.3 & 15.7 & \\
\hline $1 R-1,75-79$ & 82.6 & 13.9 & \\
\hline $1 \mathrm{R}-1,75-79$ & 71.2 & 25.7 & \\
\hline $9 \mathrm{R}-1,113-118$ & 78.0 & 18.5 & \\
\hline $12 \mathrm{R}-2,120-124$ & 83.4 & 13.3 & \\
\hline $12 \mathrm{R}-2,120-124$ & 76.0 & 20.9 & \\
\hline $13 R-1,34-36$ & 86.0 & 12.2 & \\
\hline $13 \mathrm{R}-1,34-36$ & 71.5 & 25.7 & \\
\hline $30 \mathrm{R}-1,29-31$ & 74.3 & 23.0 & \\
\hline $30 \mathrm{R}-1,29-31$ & 77.3 & 19.6 & \\
\hline $31 \mathrm{R}-2,86-87$ & 86.1 & 11.6 & \\
\hline $31 \mathrm{R}-2,86-87$ & 71.4 & 24.5 & \\
\hline $43 \mathrm{R}-2,43-52$ & 84.7 & 12.7 & \\
\hline $43 R-2,43-52$ & 76.4 & 21.1 & \\
\hline $49 R-4,32-37$ & 69.7 & 26.7 & \\
\hline $49 \mathrm{R}-4,32-37$ & 74.3 & 23.0 & \\
\hline $17 R-1.67-69$ & 71.1 & 25.1 & \\
\hline $17 \mathrm{R}-1,81-83$ & 64.9 & 31.7 & \\
\hline $17 \mathrm{R}-1,81-83$ & 81.1 & 15.1 & \\
\hline $15 R-2,3-8$ & 60.6 & 35.9 & \\
\hline $15 \mathrm{R}-2,3-8$ & 68.2 & 28.6 & \\
\hline $19 \mathrm{R}-1,91-94$ & 63.5 & 28.7 & \\
\hline $19 R-1,91-94$ & 59.6 & 31.0 & \\
\hline $24 R-2,5-9$ & 66.0 & 31.1 & \\
\hline $21 \mathrm{R}-1,129-132$ & 52.0 & 45.0 & \\
\hline $21 \mathrm{R}-1,129-132$ & 48.4 & 48.4 & \\
\hline $21 \mathrm{R}-2,28-32$ & 47.6 & 48.9 & \\
\hline $21 \mathrm{R}-2,28-32$ & 51.7 & 45.2 & \\
\hline
\end{tabular}

dominated by unzoned olivine and enstatite, the LCBrzAs contain abundant augite with $\mathrm{Mg \#}=70 \%$ to $<85 \%$ and plagioclase with $55 \%$ to $80 \%$ anorthite, and minerals are strongly zoned.

\section{Intermediate-Ca Boninite}

Intermediate- $\mathrm{Ca}$ boninites and their derivative, intermediate-Ca bronzite andesites form the dominant lithology of Hole 786B. All three igneous episodes produced ICB magmas (Mitchell et al., this volume). The ICBs of the edifice-building igneous episode (40 to $42 \mathrm{Ma}$ ) make up Cores 125-786B-51R to $-55 \mathrm{R}$ and parts of Cores $125-786 \mathrm{~B}-10 \mathrm{R}$ to $-13 \mathrm{R}$. The locations of five younger dikes/sills are indicated in the lithologic column (Fig. 1) and additional ICB samples were recovered from Hole 786A. Mineral compositions of ICBs are presented in Tables 1 to 5 . The mineral compositions of the oldest generation of ICBs ( 40 to $42 \mathrm{Ma}$ ) are plotted in Figure 3 and those of the younger ICBs ( 34 to $35 \mathrm{Ma}$ and $\approx 17 \mathrm{Ma}$ ) are plotted in Figure 4 . Note the well-developed zonation in the mafic minerals of the 40 - to 42-Ma ICBs and the absence of such zonation in the younger ICBs. The young ICB dikes and sills commonly contain $5 \%$ to $10 \%$ phenocrysts and are each petrographically distinct. The old ICBs are more crystal-rich and commonly have $15 \%$ to $25 \%$ phenocrysts.

Generally a trace to $5 \%$ olivine, or olivine relics, is present in ICBs, sometimes rimmed by orthopyroxene. The 40- to 42-Ma ICBs of Subunit 26 (Core 125-786B-51R to $-55 \mathrm{R}$ ) are similar to those of Subunit 4 except that the latter are olivine free (N.B., ICB samples of Subunit 4 are included with bronzite andesites in Fig. 7). No olivine was preserved that could be analyzed in the 40- to 42-Ma samples.

The youngerdikes yielded the freshest samples (Cooling Unit 13XCC and Core 125-786B-37R). Olivine in Cooling Unit 13XCC with $90.2 \%$ forsterite shows signs of resorption but that with $86.6 \%$ forsterite is euhedral. Sample 125-786B-37R-3,31-35 cm, is from the glassy margin of the sill of Subunit 21. This sample and Sample 125-786B-37R-1, $95-98 \mathrm{~cm}$, both from the sill, contain olivine (micro)phenocrysts of $86.6 \%$ to $87.1 \%$ forsterite. The sill is a clear example of crystal settling processes operating during solidification. Orthopyroxene, and to a greater extent olivine, are concentrated near the bottom while plagioclase is enriched near the top. Section 125-786B-44R-1 samples are distinct in that they contain only olivine phenocrysts, which are present in larger amounts of $5 \%$ to $15 \%$. Traces of $\mathrm{Cr}$-spinel are commonly present as inclusions in olivine.

Orthopyroxene is always present (except in Section 125-786B$44 \mathrm{R}-1)$ and is normally euhedral except for the Cooling Unit $11 \mathrm{R} 1$ a samples which contain resorbed bronzite $(\mathrm{Mg} \#=83 \%$ to $75 \%$ ) some of which is jacketed by enstatite of $\mathrm{Mg} \#=89.4 \%$ to $89.7 \%$. Groundmass orthopyroxene can also be high in $\mathrm{Mg}$ number in these samples. The modal amounts of orthopyroxene and the $\mathrm{Mg}$ numbers and zoning patterns are highly variable in the ICBs and indicative of magma mixing in some samples (Core $125-786 \mathrm{~B}-51 \mathrm{R}$ to $-55 \mathrm{R}$ ). The young dikes and sills lack zonation in their orthopyroxene phenocrysts.

Augite is always present (except in Section 125-786B-44R-1) in trace amounts to $4 \%$. It is subhedral to euhedral but has a resorbed appearance in Section 125-786B-51R-1.

Plagioclase can be present in small amounts and usually is strongly corroded often assuming a "ball" morphology (Pl. 1F). The samples from Cooling Unit 11R1 and 11R1a are an exception again in that they contain euhedral plagioclase as well as resorbed anhedral plagioclase. In general, plagioclase cores can be as high as $\mathrm{An}=85 \%$ and rims as low as $\mathrm{An}=65 \%$, and zonation may be oscillatory.

The groundmass of the ICBs is variably crystalline consisting of acicular augite and plagioclase and rarely orthopyroxene (Core 11R1) or olivine (Section 125-786B-44R-1). Magnetite is generally present.

\section{High-Ca Boninite}

High-Ca boninite (HCB) dikes and/or sills of $34 \mathrm{Ma}$ and of younger age were injected throughout the 40- to 42-Ma volcanic edifice (Mitchell et al., this volume). At least seven dikes/sills have been recognized and are marked in the lithologic column of Figure 1. HCBs have also been recovered from Hole 786A, stratigraphically above the Hole 786B sequence. HCB magmas are not associated with the first 40- to 42-Ma igneous episode (Mitchell et al., this volume). Mineral compositions are listed in Tables 2 to 5.

HCBs contain $3 \%$ to $5 \%$ of olivine relics and a trace to $8 \%$ of bronzite, with $\mathrm{Mg}$ numbers ranging from $76 \%$ to $87 \%$. Orthopyroxene does not mantle olivine in HCBs. Traces to $3 \%$ augite occur in all HCBs except for those in Section 125-786B-40R-2. Augite is commonly corroded and appears to be resorbed but such anhedral crystals can also be found with euhedral crystals. Mg numbers of augite are $82 \%$ to $88 \%$ and equal those of orthopyroxene in 
Table 3. Representative clinopyroxene analyses.

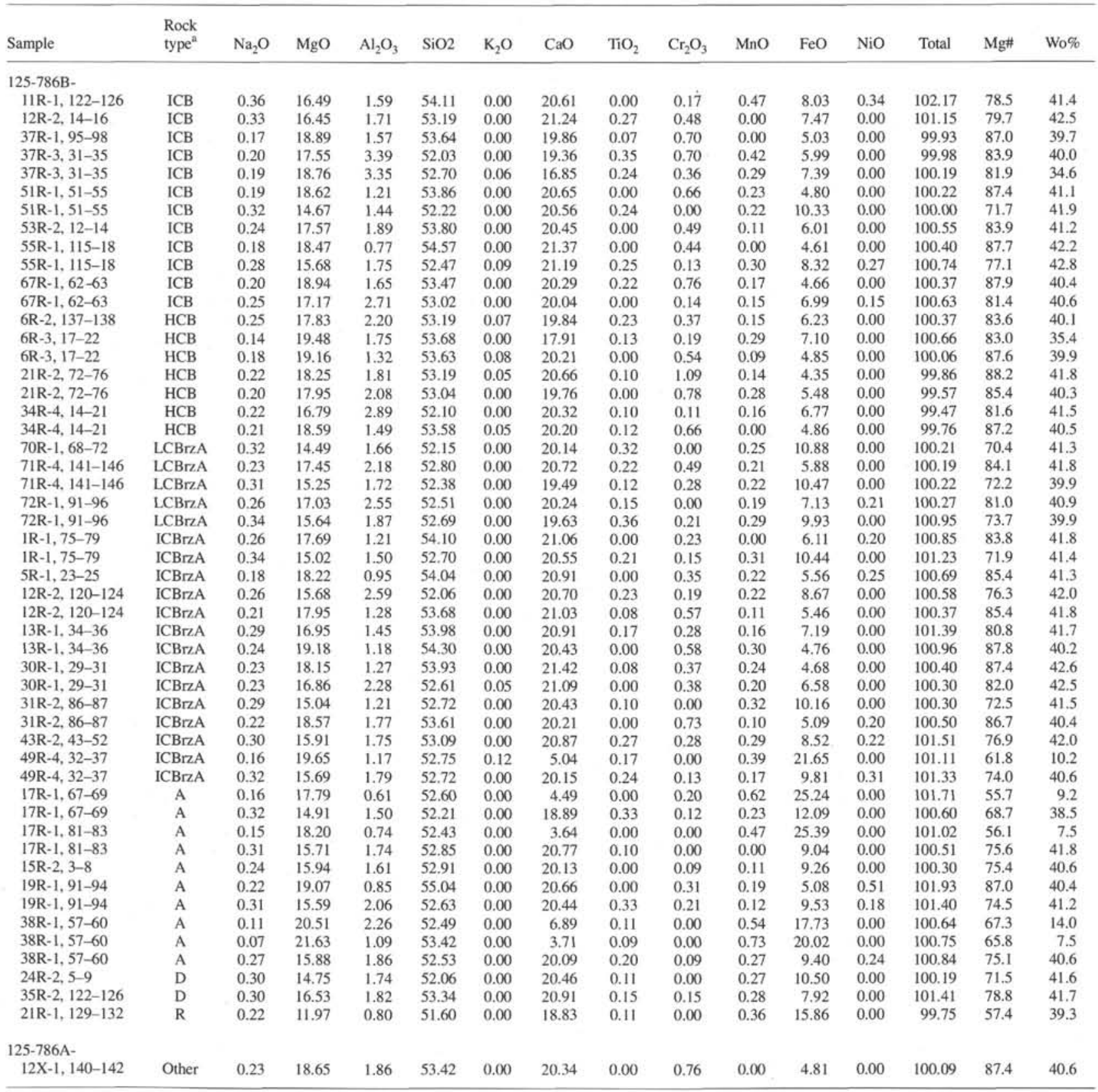

Notes: $\mathrm{Wo} \%=\mathrm{Ca} /(\mathrm{Ca}+\mathrm{Mg}+\mathrm{Fe}) ; \mathrm{En} \%=\mathrm{Mg} /(\mathrm{Ca}+\mathrm{Mg}+\mathrm{Fe}) ; \mathrm{Fs} \%=\mathrm{Fe} /(\mathrm{Ca}+\mathrm{Mg}+\mathrm{Fe})$, all in mol\%

${ }^{\mathrm{a}} \mathrm{ICB}=$ intermediate-Ca boninite, $\mathrm{HCB}=$ high-Ca boninite, $\mathrm{LCBrz} \mathrm{A}=$ low-Ca bronzite andesite, $\mathrm{ICBrz} \mathrm{A}=$ intermediate-Ca bronzite andesite, $\mathrm{A}=$ andesite, $\mathrm{D}=$ dacite, and $\mathrm{R}=$ rhyolite.

Section 125-786B-34R-4 but are higher in Section 125-786B-6R-2. Zonation is minor (see Fig. 5) and aggregates of orthopyroxene and augite are common in all samples. Plagioclase, if present, is always anhedral and its corroded appearance is evidence for resorption. Cr-spinel is present in all but Sample 125-786B-21R-2, 103-105 cm. It is very dark red to almost opaque in Section 125-786B-40R-2.

The groundmass is $30 \%$ to $80 \%$ crystalline and contains prismatic augite (Mg numbers similar to the phenocrysts) and acicular plagioclase ( $68 \%$ to $72 \% \mathrm{An}$ ), set in more-or-less altered glass. A trace to $1 \%$ of magnetite is present in the groundmass.

\section{Bronzite Andesite}

\section{Intermediate-Ca Bronzite Andesite}

Intermediate-Ca bronzite andesite (ICBrzA) is the most abundant rock type of Hole 786B. It forms the dominant lithology in Cores $125-786 \mathrm{~B}-1 \mathrm{R}$ to $-13 \mathrm{R}$ at the top of the sequence, and in Cores 125-786B-27R to -50R. Low-Ca bronzite andesites make up the base of the sequence of Hole 786B, and are described together with the low-Ca boninites in the previous section. All bronzite andesites were produced during the first igneous episode, 40 to $42 \mathrm{Ma}$ (Mitchell et 
Table 3 (continued).

\begin{tabular}{|c|c|c|}
\hline Sample & En\% & Fs\% \\
\hline \multicolumn{3}{|l|}{ 125-786B- } \\
\hline $11 R-1,122-126$ & 46.0 & 12.6 \\
\hline $12 \mathrm{R}-2,14-16$ & 45.8 & 11.7 \\
\hline 37R-1, 95-98 & 52.5 & 7.8 \\
\hline $37 \mathrm{R}-3,31-35$ & 50.4 & 9.6 \\
\hline $37 \mathrm{R}-3,31-35$ & 53.6 & 11.8 \\
\hline $51 R-1,51-55$ & 51.5 & 7.4 \\
\hline 51R-1, 51-55 & 41.6 & 16.4 \\
\hline $53 \mathrm{R}-2,12-14$ & 49.3 & 9.5 \\
\hline $55 \mathrm{R}-1,115-18$ & 50.7 & 7.1 \\
\hline $55 \mathrm{R}-1,115-18$ & 44.1 & 13.1 \\
\hline $67 R-1,62-63$ & 52.4 & 7.2 \\
\hline $67 R-1,62-63$ & 48.4 & 11.0 \\
\hline $6 R-2,137-138$ & 50.1 & 9.8 \\
\hline $6 \mathrm{R}-3,17-22$ & 53.6 & 11.0 \\
\hline $6 \mathrm{R}-3,17-22$ & 52.6 & 7.5 \\
\hline $21 \mathrm{R}-2,72-76$ & 51.3 & 6.9 \\
\hline $21 \mathrm{R}-2,72-76$ & 51.0 & 8.7 \\
\hline $34 \mathrm{R}-4,14-21$ & 47.7 & 10.8 \\
\hline $34 \mathrm{R}-4,14-21$ & 51.9 & 7.6 \\
\hline $70 \mathrm{R}-1,68-72$ & 41.3 & 17.4 \\
\hline $71 R-4,141-146$ & 49.0 & 9.3 \\
\hline $71 R-4,141-146$ & 43.4 & 16.7 \\
\hline $72 \mathrm{R}-1,91-96$ & 47.9 & 11.2 \\
\hline $72 \mathrm{R}-1,91-96$ & 44.3 & 15.8 \\
\hline $1 \mathrm{R}-1,75-79$ & 48.8 & 9.5 \\
\hline IR-1, 75-79 & 42.1 & 16.4 \\
\hline $5 R-1,23-25$ & 50.1 & 8.6 \\
\hline $12 \mathrm{R}-2,120-124$ & 44.3 & 13.7 \\
\hline $12 \mathrm{R}-2,120-124$ & 49.7 & 8.5 \\
\hline $13 \mathrm{R}-1,34-36$ & 47.1 & 11.2 \\
\hline $13 \mathrm{R}-1,34-36$ & 52.5 & 7.3 \\
\hline $30 \mathrm{R}-1,29-31$ & 50.2 & 7.3 \\
\hline $30 \mathrm{R}-1,29-31$ & 47.2 & 10.3 \\
\hline $31 \mathrm{R}-2,86-87$ & 42.5 & 16.1 \\
\hline $31 \mathrm{R}-2,86-87$ & 51.7 & 7.9 \\
\hline $43 R-2,43-52$ & 44.6 & 13.4 \\
\hline $49 \mathrm{R}-4,32-37$ & 55.5 & 34.3 \\
\hline $49 R-4,32-37$ & 44.0 & 15.4 \\
\hline $17 \mathrm{R}-1,67-69$ & 50.6 & 40.3 \\
\hline $17 \mathrm{R}-1,67-69$ & 42.3 & 19.2 \\
\hline $17 \mathrm{R}-1,81-83$ & 51.9 & 40.6 \\
\hline $17 \mathrm{R}-1,81-83$ & 44.0 & 14.2 \\
\hline $15 R-2,3-8$ & 44.8 & 14.6 \\
\hline 19R-1, 91-94 & 51.9 & 7.8 \\
\hline 19R-1, 91-94 & 43.8 & 15.0 \\
\hline $38 \mathrm{R}-1,57-60$ & 57.9 & 28.1 \\
\hline $38 \mathrm{R}-1,57-60$ & 60.9 & 31.6 \\
\hline $38 \mathrm{R}-1,57-60$ & 44.6 & 14.8 \\
\hline $24 R-2,5-9$ & 41.7 & 16.7 \\
\hline $35 R-2,122-126$ & 45.9 & 12.3 \\
\hline $21 \mathrm{R}-1,129-132$ & 34.8 & 25.9 \\
\hline \multicolumn{3}{|l|}{$125-786 \mathrm{~A}$ - } \\
\hline $12 X-1,140-142$ & 51.9 & 7.5 \\
\hline
\end{tabular}

al., this volume). In the figures, we have opted to present the ICBrzAs in stratigraphical order and occasionally included locally interspersed ICBs, andesites, and dacites when convenient. Figures 6 and 7 show the mineral compositions of ICBRzAs, ICBs, and andesite from Cores $125-786 \mathrm{~B}-1 \mathrm{R}$ to $-13 \mathrm{R}$. Figure 8 presents mineral compositions of ICBrzAs and dacite from Cores $125-786 \mathrm{~B}-30 \mathrm{R}$ to $-35 \mathrm{R}$, and Figure 9 contains ICBrzA and andesite mineral compositions from Cores $125-786 \mathrm{~B}-37 \mathrm{R}$ to $-49 \mathrm{R}$. These figures are most informative about zonation patterns and compositional ranges of minerals in individual samples, and the more generalized description of ICBrzAs follows in this section. The detailed petrography of each sample is documented in the Appendix (in back pocket). Selected mineral analyses are included in Tables 2 to 5 .
ICBrzAs are invariably crystal-rich and contain at least $15 \%$ but in general $20 \%$ to $35 \%$ phenocryst. Olivine and $\mathrm{Cr}$-spinel may be present in ICBrzAs but no fresh olivine was found. Olivine relics can have orthopyroxene coronas. Orthopyroxene and augite coexist in all ICBrzA samples. Orthopyroxene ( $2 \%$ to $20 \%$ ) can be euhedral or anhedral with signs of resorption. Overgrowth rims, both of higher or lower $\mathrm{Mg}$ number, can be seen in some samples on resorbed orthopyroxene crystals. Augite (3\% to $10 \%$ ) is present in all samples as euhedral phenocrysts, although anhedral, resorbed crystals were also found in a small number of samples. $\mathrm{Mg}$ numbers of coexisting pyroxenes are similar and lie between $70 \%$ to $88.5 \%$

Plagioclase is always present and can be euhedral, but clearly resorbed crystals or crystal aggregates with a "ball" shape are most common (Pl. 1F). Plagioclase can be unzoned or have oscillatory, normal, or reversed zonation. It appears that plagioclase with a narrow compositional range of $60 \%$ to $75 \%$ An is stable in ICBrzAs, while that of higher or lower anorthite content tends to be resorbed. Magnetite does not occur as phenocrysts.

The groundmass consists of prismatic and/or acicular plagioclase of $\mathrm{An}=55 \%$ to $85 \%$ and augite of $\mathrm{Mg} \#=65 \%$ to $85 \%$. Orthopyroxene can be present. Magnetite is commonly absent but can be present in trace to $1 \%$ amounts. Some of the Section 125-786B-42R-1 samples contain up to $5 \%$ magnetite in the groundmass.

\section{Andesites and Dacites}

The andesites (A) and dacites (D) are part of the old volcanic construct which formed during the first igneous episode (40-42 Ma). Their mineral compositions, together with those of the rhyolites (R), are presented in Figures 10 and 11 and in Tables 2 to 4.

The andesites and dacites generally bear abundant phenocrysts of plagioclase ( $3 \%$ to $20 \%$ ), a trace to $5 \%$ of augite, and subordinate orthopyroxene ( $0 \%$ to $5 \%)$. Plagioclase has a prismatic to lath shape and can be euhedral or resorbed in which case it can assume a ball-like form. Very inclusion-rich plagioclase with a sieve-like texture is common. Plagioclase occurs as individual crystals and in aggregates with augite and orthopyroxene. Different types of plagioclase can be found together (e.g., in Section 125-786B-35R-2, plagioclase of $48 \%$ to $58 \% \mathrm{An}$ is euhedral while that of $45 \% \mathrm{An}$ and $78 \%$ to $80 \% \mathrm{An}$ is resorbed). Augite is usually subhedral and shows signs of resorption. Its $\mathrm{Mg}$ numbers lie in the range of $70 \%$ to $79 \%$. Orthopyroxene is euhedral with $\mathrm{Mg} \#=62 \%$ to $76 \%$ and rarely is resorbed. Orthopyroxene has lower $\mathrm{Mg}$ numbers than its coexisting augite.

Pigeonite, orthopyroxene, and augite form the groundmass minerals in addition to plagioclase and traces of magnetite. Some samples contain quartz and/or amphibole in the groundmass (e.g., in Section 125-786B-35R-2).

\section{Rhyolites}

All rhyolite magmas were produced during the first episode of igneous activity. Fresh rhyolitic samples were only found in Cooling Unit $21 \mathrm{R} 1 \mathrm{a}$. The rhyolites are sparsely phyric with $1 \%$ to $2 \%$ of euhedral plagioclase ( $45 \%$ to $50 \% \mathrm{An}$ ), commonly in aggregates. Mineral compositions and zoning profiles are presented in Figures 11 and Tables 3 to 5 . Rhyolites contain traces of euhedral and/or resorbed, anhedral augite $(\mathrm{Mg} \#=57 \%)$ and hypersthene $(\mathrm{Mg} \#=50 \%$ to $52 \%$ ) and always contain magnetite as phenocrysts. Zonation is minor in the analyzed minerals. The phenocrysts are set in a largely glassy matrix of rhyolitic compositions, with small needle-shaped crystals of mainly clinopyroxene and some hypersthene. The glass varies in color from light to dark brown and is bright yellow from alteration along concentric fractures (perlitic alteration). Samples from farther downhole (i.e., from Cooling Unit 32R2a on) have been altered to a great degree and never contain fresh glass. In Cooling 
Table 4. Representative plagioclase analyses.

\begin{tabular}{|c|c|c|c|c|c|c|c|c|c|c|c|c|c|c|c|c|}
\hline Sample & $\begin{array}{l}\text { Rock } \\
\text { type }^{\mathrm{a}}\end{array}$ & $\mathrm{Na}_{2} \mathrm{O}$ & $\mathrm{MgO}$ & $\mathrm{Al}_{2} \mathrm{O}_{3}$ & $\mathrm{SiO} 2$ & $\mathrm{~K}_{2} \mathrm{O}$ & $\mathrm{CaO}$ & $\mathrm{TiO}_{2}$ & $\mathrm{Cr}_{2} \mathrm{O}_{3}$ & $\mathrm{MnO}$ & $\mathrm{FeO}$ & $\mathrm{NiO}$ & Total & An\% & $\mathrm{Ab} \%$ & Or\% \\
\hline \multicolumn{17}{|l|}{$125-786 \mathrm{~B}-$} \\
\hline $11 R-1,122-126$ & ICB & 2.34 & 0.08 & 32.26 & 48.53 & 0.09 & 16.32 & 0.09 & 0.11 & 0.00 & 0.82 & 0.24 & 100.88 & 84.7 & 14.5 & 0.4 \\
\hline $11 R-1,122-126$ & ICB & 4.35 & 0.10 & 28.62 & 53.81 & 0.00 & 12.90 & 0.00 & 0.00 & 0.14 & 0.82 & 0.00 & 100.74 & 71.4 & 28.6 & 0.0 \\
\hline $11 \mathrm{R}-1,122-126$ & ICB & 1.61 & 0.05 & 32.98 & 47.01 & 0.08 & 17.70 & 0.00 & 0.00 & 0.00 & 0.68 & 0.00 & 100.11 & 89.5 & 9.7 & 0.4 \\
\hline $12 \mathrm{R}-2,14-16$ & ICB & 4.49 & 0.16 & 28.82 & 53.81 & 0.00 & 12.31 & 0.00 & 0.00 & 0.00 & 0.88 & 0.19 & 100.66 & 69.7 & 30.3 & 0.0 \\
\hline $12 \mathrm{R}-2,14-16$ & ICB & 3.53 & 0.17 & 30.12 & 51.33 & 0.00 & 14.12 & 0.10 & 0.00 & 0.00 & 0.81 & 0.22 & 100.40 & 77.1 & 22.9 & 0.0 \\
\hline $12 \mathrm{R}-2,14-16$ & ICB & 2.75 & 0.09 & 31.14 & 49.22 & 0.00 & 15.43 & 0.00 & 0.00 & 0.00 & 0.83 & 0.00 & 99.46 & 82.5 & 17.5 & 0.0 \\
\hline $37 \mathrm{R}-3,31-35$ & ICB & 3.25 & 0.31 & 29.91 & 51.52 & 0.00 & 14.25 & 0.00 & 0.00 & 0.00 & 0.80 & 0.00 & 100.04 & 78.6 & 21.4 & 0.0 \\
\hline $37 \mathrm{R}-1,95-98$ & ICB & 6.96 & 0.02 & 26.09 & 58.34 & 0.06 & 8.38 & 0.09 & 0.00 & 0.00 & 0.28 & 0.00 & 100.20 & 50.0 & 49.4 & 0.3 \\
\hline $37 \mathrm{R}-1,95-98$ & ICB & 3.16 & 0.10 & 30.98 & 50.21 & 0.02 & 14.82 & 0.01 & 0.22 & 0.00 & 0.69 & 0.00 & 100.20 & 79.6 & 20.2 & 0.1 \\
\hline $51 \mathrm{R}-1,51-55$ & ICB & 2.25 & 0.06 & 32.45 & 47.90 & 0.00 & 16.42 & 0.07 & 0.10 & 0.13 & 0.69 & 0.00 & 100.06 & 86.0 & 14.0 & 0.0 \\
\hline $51 R-1,51-55$ & ICB & 3.42 & 0.07 & 30.84 & 50.52 & 0.00 & 14.53 & 0.00 & 0.14 & 0.00 & 0.67 & 0.00 & 100.19 & 78.1 & 21.9 & 0.0 \\
\hline $53 \mathrm{R}-2,12-14$ & ICB & 3.71 & 0.10 & 30.33 & 51.40 & 0.04 & 13.69 & 0.08 & 0.00 & 0.00 & 0.69 & 0.00 & 100.04 & 75.3 & 24.3 & 0.2 \\
\hline $53 R-2,12-14$ & ICB & 2.14 & 0.08 & 32.71 & 47.45 & 0.00 & 16.28 & 0.00 & 0.00 & 0.00 & 0.67 & 0.00 & 99.32 & 86.5 & 13.5 & 0.0 \\
\hline $55 \mathrm{R}-1,115-18$ & ICB & 3.26 & 0.14 & 29.95 & 50.92 & 0.00 & 14.15 & 0.00 & 0.00 & 0.00 & 0.90 & 0.00 & 99.32 & 78.5 & 21.5 & 0.0 \\
\hline $6 \mathrm{R}-2,137-138$ & $\mathrm{HCB}$ & 3.05 & 0.25 & 30.24 & 50.14 & 0.00 & 14.97 & 0.00 & 0.00 & 0.19 & 0.92 & 0.00 & 99.78 & 80.5 & 19.5 & 0.0 \\
\hline $6 \mathrm{R}-3,17-22$ & $\mathrm{HCB}$ & 3.01 & 0.29 & 30.89 & 49.95 & 0.00 & 14.92 & 0.00 & 0.00 & 0.00 & 0.76 & 0.00 & 99.81 & 80.6 & 19.4 & 0.0 \\
\hline $34 R-4,14-21$ & HCB & 3.49 & 0.25 & 29.76 & 52.00 & 0.00 & 13.77 & 0.00 & 0.00 & 0.00 & 0.64 & 0.00 & 99.92 & 76.8 & 23.2 & 0.0 \\
\hline $70 R-1,68-72$ & LCBrzA & 4.93 & 0.06 & 27.22 & 56.62 & 0.10 & 10.52 & 0.00 & 0.00 & 0.00 & 0.49 & 0.00 & 99.95 & 63.5 & 35.4 & 0.5 \\
\hline $71 R-4,141-146$ & LCBrzA & 5.21 & 0.10 & 27.80 & 54.89 & 0.08 & 11.50 & 0.08 & 0.16 & 0.00 & 0.78 & 0.00 & 100.60 & 64.4 & 34.8 & 0.4 \\
\hline $71 R-4,141-146$ & LCBrzA & 2.57 & 0.03 & 32.27 & 48.09 & 0.00 & 15.77 & 0.12 & 0.00 & 0.00 & 0.57 & 0.00 & 99.42 & 83.7 & 16.3 & 0.0 \\
\hline $72 \mathrm{R}-1,91-96$ & LCBrzA & 2.37 & 0.04 & 32.57 & 48.04 & 0.00 & 16.07 & 0.00 & 0.00 & 0.00 & 0.61 & 0.00 & 99.71 & 85.1 & 14.9 & 0.0 \\
\hline $72 R-1,91-96$ & LCBrzA & 4.82 & 0.20 & 25.99 & 57.44 & 0.13 & 10.66 & 0.14 & 0.00 & 0.00 & 0.93 & 0.16 & 100.47 & 64.1 & 34.5 & 0.7 \\
\hline IR-1,75-79 & ICBrzA & 4.99 & 0.07 & 27.65 & 55.12 & 0.10 & 11.58 & 0.00 & 0.00 & 0.00 & 0.77 & 0.25 & 100.52 & 65.4 & 33.6 & 0.5 \\
\hline IR-1, 75-79 & ICBrzA & 3.75 & 0.08 & 29.66 & 52.01 & 0.00 & 13.84 & 0.00 & 0.22 & 0.00 & 0.90 & 0.30 & 100.76 & 75.6 & 24.4 & 0.0 \\
\hline $9 \mathrm{R}-1,113-118$ & ICBrzA & 2.55 & 0.12 & 31.96 & 48.60 & 0.00 & 15.92 & 0.07 & 0.00 & 0.14 & 0.62 & 0.00 & 99.98 & 84.0 & 16.0 & 0.0 \\
\hline $12 \mathrm{R}-2,120-124$ & ICBrzA & 4.85 & 0.06 & 28.18 & 55.20 & 0.00 & 11.34 & 0.13 & 0.00 & 0.00 & 0.57 & 0.00 & 100.32 & 66.3 & 33.7 & 0.0 \\
\hline $12 \mathrm{R}-2,120-124$ & ICBrzA & 2.02 & 0.05 & 33.25 & 46.72 & 0.00 & 16.82 & 0.00 & 0.00 & 0.00 & 0.66 & 0.19 & 99.71 & 87.5 & 12.5 & 0.0 \\
\hline $13 R-1,34-36$ & ICBrzA & 5.19 & 0.07 & 27.29 & 56.19 & 0.09 & 10.88 & 0.13 & 0.00 & 0.14 & 0.57 & 0.00 & 100.55 & 63.2 & 35.9 & 0.5 \\
\hline $13 R-1,34-36$ & ICBrzA & 1.52 & 0.07 & 33.32 & 46.45 & 0.00 & 17.57 & 0.00 & 0.00 & 0.00 & 0.60 & 0.00 & 99.52 & 90.7 & 9.3 & 0.0 \\
\hline $30 \mathrm{R}-1,29-31$ & ICBrzA & 5.07 & 0.07 & 27.85 & 56.25 & 0.07 & 11.23 & 0.02 & 0.00 & 0.12 & 0.58 & 0.00 & 101.30 & 64.6 & 34.7 & 0.4 \\
\hline $3 \mathrm{OR}-1,29-31$ & ICBrzA & 1.24 & 0.10 & 34.08 & 45.93 & 0.04 & 18.11 & 0.00 & 0.00 & 0.00 & 0.57 & 0.00 & 100.10 & 92.1 & 7.5 & 0.2 \\
\hline 3 IR-2, 86-87 & ICBrzA & 1.96 & 0.08 & 32.92 & 47.12 & 0.00 & 16.88 & 0.00 & 0.00 & 0.13 & 0.66 & 0.00 & 99.76 & 87.9 & 12.1 & 0.0 \\
\hline $31 \mathrm{R}-2,86-87$ & ICBrzA & 5.44 & 0.08 & 27.53 & 55.58 & 0.00 & 10.74 & 0.00 & 0.00 & 0.00 & 0.57 & 0.25 & 100.20 & 62.4 & 37.6 & 0.0 \\
\hline $43 \mathrm{R}-2,43-52$ & ICBrzA & 2.50 & 0.06 & 32.45 & 48.26 & 0.00 & 16.04 & 0.00 & 0.00 & 0.00 & 0.56 & 0.00 & 99.87 & 84.3 & 15.7 & 0.0 \\
\hline $49 R-4,32-37$ & ICBrzA & 2.92 & 0.09 & 30.84 & 50.17 & 0.00 & 15.30 & 0.00 & 0.00 & 0.00 & 0.92 & 0.3 & 100.62 & 81.5 & 18.5 & 0.0 \\
\hline $17 \mathrm{R}-1,67-69$ & A & 4.60 & 0.06 & 28.23 & 53.82 & 0.06 & 12.36 & 0.0 & 0. & 0.00 & 0.80 & 0.0 & 99.94 & 68.9 & 30.5 & 0.3 \\
\hline $17 \mathrm{R}-1,67-69$ & A & 2.39 & 0.08 & 31.74 & 48.96 & 0.00 & 16.31 & 0.00 & 0.13 & 0.00 & 0.89 & 0.00 & 100.49 & 85.1 & 14.9 & 0.0 \\
\hline $17 \mathrm{R}-1,81-83$ & A & 4.07 & 0.07 & 29.15 & 52.57 & 0.09 & 13.21 & 0.00 & 0.00 & 0.00 & 0.90 & 0.00 & 100.05 & 72.5 & 26.6 & 0.4 \\
\hline $17 \mathrm{R}-1,81-83$ & A & 2.13 & 0.0 & 32.11 & 47.86 & 0.05 & 16.63 & 0.00 & 0.00 & 0.00 & 0.83 & 0. & 99.69 & 86.3 & 13.2 & 0.2 \\
\hline $15 R-2,3-8$ & A & 3.34 & 0.08 & 30.62 & 50.58 & 0.07 & 14.40 & 0.00 & 0.13 & 0.00 & 0.82 & 0.29 & 100.33 & 77.8 & 21.5 & 0.3 \\
\hline $15 \mathrm{R}-2,3-8$ & A & 4.81 & 0.07 & 28.59 & 53.81 & 0.00 & 11.89 & 0.00 & 0.00 & 0.00 & 0.60 & 0.00 & 99.77 & 67.5 & 32.5 & 0.0 \\
\hline $19 R-1,91-94$ & A & 2.20 & 0.12 & 31.76 & 48.47 & 0.0 & 16.29 & 0.00 & 0.0 & 0.00 & 0.91 & 0.00 & 99.75 & 86.1 & 13.9 & 0.0 \\
\hline $38 \mathrm{R}-1,57-60$ & A & 1.57 & 0.08 & 33.69 & 46.41 & 0.00 & 17.33 & 0.00 & 00 & 0.00 & 0.79 & 0.22 & 100.10 & 90.3 & 9.7 & 0.0 \\
\hline $38 \mathrm{R}-1,57-60$ & A & 2.78 & 0.11 & 31.55 & 49.80 & 0.06 & 15.41 & 0.00 & 0.08 & 0.00 & 0.88 & 0.00 & 100.68 & 81.9 & 17.6 & 0.3 \\
\hline $24 \mathrm{R}-2,5-9$ & D & 4.83 & 0.07 & 28.48 & 53.45 & 0.00 & 11.82 & 0.00 & 000 & 0.00 & 0.63 & 0.00 & 99.29 & 67.3 & 32.7 & 0.0 \\
\hline $24 \mathrm{R}-2,5-9$ & D & 2.62 & 0.08 & 31.68 & 48.28 & 0.05 & 15.59 & 0.00 & 0.00 & 0.08 & 0.78 & 0.00 & 99.17 & 82.9 & 16.6 & 0.2 \\
\hline $35 \mathrm{R}-2,122-126$ & D & 5.99 & 0.02 & 26.62 & 56.73 & 0.09 & 10.02 & 0.00 & 000 & 0.00 & 0.58 & 0.36 & 100.41 & 57.9 & 41.2 & 0.5 \\
\hline $35 \mathrm{R}-2,122-126$ & D & 4.50 & 0.06 & 28.71 & 53.33 & 0.00 & 12.60 & 0.00 & 0.00 & 0.16 & 0.78 & 0.00 & 100.13 & 70.2 & 29.8 & 0.0 \\
\hline $35 \mathrm{R}-2,122-126$ & D & 6.27 & 0.03 & 26.07 & 58.05 & 0.00 & 9.51 & 0.00 & 0.00 & 0.00 & 0.62 & 0.00 & 100.53 & 56.0 & 44.0 & 0.0 \\
\hline 2 IR $-1,129-132$ & $\mathbf{R}$ & 6.70 & 0.03 & 25.84 & 58.29 & 0.07 & 8.59 & 0.00 & 0.11 & 0.00 & 0.36 & 0.00 & 99.99 & 51.5 & 47.8 & 0.4 \\
\hline 2 IR-1, 129-132 & R & 5.78 & 0.04 & 27.18 & 56.52 & 0.06 & 10.11 & 0.00 & 0.13 & 0.00 & 0.40 & 0.00 & 100.21 & 59.1 & 40.2 & 0.3 \\
\hline $21 \mathrm{R}-2,28-32$ & $\mathrm{R}$ & 6.16 & 0.02 & 26.85 & 56.65 & 0.00 & 9.74 & 0.00 & 0.00 & 0.00 & 0.40 & 0.00 & 99.83 & 57.0 & 43.0 & 0.0 \\
\hline \multicolumn{17}{|l|}{$125-786 \mathrm{~A}$} \\
\hline 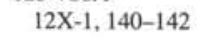 & Other & 3.30 & 0.09 & 30.31 & 50.55 & 0.00 & 14.55 & 0.00 & 0.00 & 0.00 & 0.75 & 0.00 & 99.55 & 78.7 & 21.3 & 0.0 \\
\hline \multicolumn{17}{|l|}{ 125-786B- } \\
\hline $15 \mathrm{R}-1,0-$ & Other & 4.40 & 0.04 & 29.05 & 53.02 & 0.12 & 12.77 & 0.00 & 0.00 & 0.00 & 0.73 & 0.00 & 100.11 & 70.1 & 28.8 & 0.6 \\
\hline
\end{tabular}

Notes: $\mathrm{An} \%=\mathrm{Ca} /(\mathrm{Ca}+\mathrm{Na}+\mathrm{K}) ; \mathrm{Ab} \%=\mathrm{Na} /(\mathrm{Ca}+\mathrm{Na}+\mathrm{K}) ; \mathrm{Or} \%=\mathrm{K} /(\mathrm{Ca}+\mathrm{Na}+\mathrm{K})$, all in $\mathrm{mol} \%$.

${ }^{\mathrm{I}} \mathrm{ICB}=$ intermediate-Ca boninite, $\mathrm{HCB}=$ high-Ca boninite, $\mathrm{LCBrzA}=$ low-Ca bronzite andesite, $\mathrm{ICBrz} \mathrm{A}=$ intermediate-Ca bronzite andesite, $\mathrm{A}=$ andesite, $\mathrm{D}=$ dacite, and $\mathrm{R}=$ rhyolite.

Unit 63R2, no phenocrysts remained unaltered and relics could not be identified with any confidence.

\section{Other Volcanics}

One sample (125-786A-12X-1, 140-142 cm) from the very top of the igneous basement has a mineralogy that deviates from the previous rock types. The sample contains clinopyroxene of homogeneous composition with a high $\mathrm{Mg}$ number and resorbed plagioclase phenocrysts, and might have derived from a more basaltic parental magma. Its mineral compositions are presented in Figure 12 and in Tables 3 and 4.

\section{Cumulates}

Two small pieces of microdiorite were recovered in breccias of Samples 125-786B-15R-1, 0-1 cm, and 125-786B-17R-1, 11-20 $\mathrm{cm}$. No whole-rock samples were analyzed but a thin section was 
Table 5. Representative Cr-spinel, glass, and amphibole analyses.

\begin{tabular}{|c|c|c|c|c|c|c|c|c|c|c|c|c|c|c|c|}
\hline Sample & $\begin{array}{l}\text { Rock } \\
\text { type }\end{array}$ & $\mathrm{Na}_{2} \mathrm{O}$ & $\mathrm{MgO}$ & $\mathrm{Al}_{2} \mathrm{O}_{3}$ & $\mathrm{SiO}_{2}$ & $\mathrm{~K}_{2} \mathrm{O}$ & $\mathrm{CaO}$ & $\mathrm{TiO}_{2}$ & $\mathrm{Cr}_{2} \mathrm{O}_{3}$ & $\mathrm{MnO}$ & $\mathrm{FeO}$ & $\mathrm{NiO}$ & Total & $\mathrm{Cr} \#$ & \\
\hline \multicolumn{16}{|l|}{$125-786 \mathrm{~A}-$} \\
\hline 13X-CC, 27-29 & ICB & 0.03 & 12.36 & 16.13 & 0.47 & 0.04 & 0.06 & 0.37 & 44.50 & 0.18 & 25.59 & 0.25 & 99.96 & 64.9 & \\
\hline $125-786 \mathrm{~B}-$ & & & & & & & & & & & & & & & \\
\hline $6 \mathrm{R}-2,137-138$ & HCB & 0.10 & 12.27 & 13.19 & 0.28 & 0.06 & 0.10 & 0.18 & 51.92 & 0.23 & 22.43 & 0.23 & 100.98 & 72.5 & \\
\hline $13 \mathrm{R}-1,34-36$ & ICBrzA & 0.11 & 5.99 & 6.13 & 0.25 & 0.00 & 0.11 & 0.58 & 40.60 & 0.44 & 43.98 & 0.40 & 98.59 & 81.6 & \\
\hline $34 \mathrm{R}-4,14-21$ & $\mathrm{HCB}$ & 0.00 & 13.62 & 8.10 & 0.25 & 0.00 & 0.10 & 0.07 & 60.95 & 0.32 & 17.87 & 0.00 & 101.30 & 83.5 & \\
\hline \multicolumn{16}{|l|}{$125-786 \mathrm{~A}-$} \\
\hline $13 \mathrm{X}-\mathrm{CC}, 27-29$ & ICB & 2.80 & 5.74 & 15.67 & 57.53 & 0.27 & 9.46 & 0.22 & 0.00 & 0.00 & 6.30 & 0.00 & 97.99 & 61.9 & \\
\hline \multicolumn{16}{|l|}{ 125-786B- } \\
\hline $37 \mathrm{R}-3,31-35$ & ICB & 2.19 & 5.11 & 15.26 & 56.82 & 0.34 & 9.43 & 0.31 & 0.00 & 0.19 & 6.98 & 0.00 & 96.64 & 56.6 & \\
\hline \multirow[t]{2}{*}{$37 R-3,31-35$} & ICB & 2.17 & 5.13 & 15.29 & 57.32 & 0.14 & 9.44 & 0.53 & 0.18 & 0.00 & 7.02 & 0.00 & 97.22 & 56.6 & \\
\hline & & & & & & & & & & & & & & $\mathrm{Mg} \#$ & Wo\% \\
\hline $35 R-2,122-126$ & D & 1.12 & 8.32 & 3.43 & 50.16 & 1.54 & 10.64 & 0.36 & 0.00 & 0.43 & 23.10 & 0.28 & 99.20 & 39.1 & 26.4 \\
\hline $15 \mathrm{R}-1,0-1$ & Other & 0.83 & 19.35 & 1.55 & 56.28 & 0.13 & 11.04 & 0.57 & 0.00 & 0.38 & 9.76 & 0.00 & 99.91 & 77.9 & 24.2 \\
\hline $15 \mathrm{R}-1,0-1$ & Other & 0.93 & 19.28 & 2.11 & 54.32 & 0.25 & 11.11 & 0.40 & 0.17 & 0.25 & 9.61 & 0.00 & 98.41 & 78.1 & 24.5 \\
\hline
\end{tabular}

Notes: $\mathrm{Wo} \%=\mathrm{Ca} /(\mathrm{Ca}+\mathrm{Mg}+\mathrm{Fe}) ; \mathrm{En} \%=\mathrm{Mg} /(\mathrm{Ca}+\mathrm{Mg}+\mathrm{Fe}) ; \mathrm{Fs} \%=\mathrm{Fe} /(\mathrm{Ca}+\mathrm{Mg}+\mathrm{Fe})$, all in mol\%.

${ }^{\mathrm{a}} \mathrm{ICB}=$ intermediate-Ca boninite, $\mathrm{HCB}=$ high-Ca boninite, $\mathrm{ICBrz} \mathrm{A}=$ intermediate-Ca bronzite andesite, and $\mathrm{D}=$ dacite.

prepared of Sample 125-786B-15R-1, 0-1 cm. The sample has a typical cumulate texture and consists of subhedral plagioclase and euhedral to subhedral amphibole and magnetite and some anhedral quartz. Mineral compositions are presented in Tables 4 and 5 and in Figure 12. Plagioclase can exhibit spectacular zonation, but unzoned crystals are common. Anorthite contents range from $45 \%$ to $65 \%$. Amphiboles are variably altered and do not follow the rules of stoichiometry. The analyses of Table 5 stand out for the unusually low $\mathrm{Al}_{2} \mathrm{O}_{3}$ content of amphibole. This, and their markedly low alkali contents, strongly suggest that these amphiboles formed as lowtemperature alteration products of augite (uralitization). The original pyroxene probably had a $\mathrm{Mg} \#=80 \%$, similar to that of the amphibole now. The current composition probably results from intimate intergrowth of multiple phases (e.g., amphibole and pyroxene).

\section{Summary of Mafic Phenocryst and Corresponding Bulk-Rock Compositions}

In Figures 13, 14, and 15 we have summarized the analyses of the mafic phenocrysts in relation to their bulk-rock composition. Mineral and bulk-rock $\mathrm{Mg}$ numbers of andesites, dacites, and rhyolites are summarized in Figure 13, those of the edifice-building boninites and bronzite andesites $(40-42 \mathrm{Ma})$ in Figure 14, and those of the younger boninite dikes and sills in Figure 15.

The two andesites in Figure 13 with the highest bulk-rock $\mathrm{Mg}$ number have the highest percentage of phenocrysts ( $27 \%$ phenocrysts in Sample 125-786B-49R-4, 32-37 cm, with $\mathrm{Mg} \#=50.3 \%$ and $16 \%$ phenocrysts in Sample 125-786B-19R-1,91-94 cm). Other andesites, dacites, and rhyolites contain less than $10 \%$ phenocrysts. The andesites, dacites, and rhyolites (Fig. 13) are characterized by mafic minerals with $\mathrm{Mg}$ numbers that are generally lower than, but also overlapping with, the lower end of the range of mineral $\mathrm{Mg}$ numbers of the boninites and bronzite andesites.

Of the edifice-building boninites and bronzite andesites, the LCB samples are crystal-poor with $2 \%$ and $3 \%$ phenocrysts, but the ICBs and the bronzite andesites are crystal-rich and commonly contain $25 \%$ phenocrysts. The ICBs and bronzite andesites contain mafic minerals with a large range in $\mathrm{Mg}$ numbers (Fig. 14). The $\mathrm{Mg}$ numbers of phenocrysts with resorptional features can have extreme as well as intermediate values compared to those of coexisting euhedral minerals in the bronzite andesites. The resorbed phenocrysts with intermediate $\mathrm{Mg}$ numbers are likely to have developed their features in a melt of different composition than the hybrid magma in which they are currently found.

The young boninites (Fig. 15) are generally sparsely phyric except for the two samples with the highest bulk-rock $\mathrm{Mg}$ numbers, which have $13 \%$ and $15 \%$ phenocrysts. The low bulk-rock $\mathrm{Mg}$ number of the HCB sample (125-786B-21R-2, 72-76 cm) of Subunit 9 is attributed to alteration ( $5 \%$ olivine replaced by carbonates). A second sample (125-786B-21R-2, 102-107 cm) of this Subunit has a $\mathrm{Mg} \#=71.6$. In contrast to the boninites of the $40-$ to $42-\mathrm{Ma}$ episode, the younger boninites display a much smaller range of phenocryst $\mathrm{Mg}$ numbers, and resorbed crystals are rare and always have extreme $\mathrm{Mg}$ numbers.

Of the samples we examined in Figure 14 and 15, the high $\mathrm{Mg}$ numbers for ICBs of all ages are likely to be attributed to crystal accumulation. However, the high Mg numbers of the LCBs cannot be explained by such a mechanism.

\section{DISCUSSION}

\section{Crystallization Sequences for Supra-Subduction Zone Magmas}

The boninite series crystallization sequence is distinct from that of calc-alkaline series rocks. In Figure 16, examples of generalized crystallization sequences of calc-alkaline rocks from various locations in Japan and from the Andes (Sakuyama, 1983) are contrasted with those of low-Ca boninite and intermediate-Ca boninite from Site 786. A crystallization sequence represents the order of progressive appearance of equilibrium mineral assemblages, as observed in a series of cogenetic rocks. A multitude of equilibrium parameters and nonequilibrium effects determines which mineral assemblage will be actually present. The impact of all of these factors on the assemblage is often difficult to evaluate and nonequilibrium effects are hard to eliminate from the observations. Some factors which tend to make the crystallization sequence less obvious are (1) variable degrees of crystallization, (2) magma mixing, (3) kinetics of crystallization and resorption, (4) variable volatile contents of magmas, (5) polybaric crystallization, and (6) physical processes of phenocryst redistribution. Crystallization sequences can therefore only be approximately deduced.

Natland (1981) in his study of boninites from Site 458 emphasized the strong dependence of textures on cooling rates and equilibrium temperatures of crystallization. These are also the reasons that not all 
Table 5 (continued).

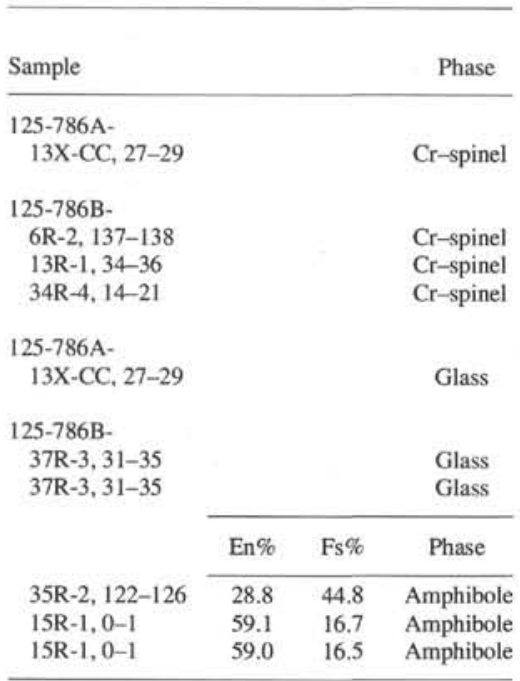

boninite samples of our study display the assemblage in accord with the crystallization sequence of Figure 16.

The following differences are important between the crystallization sequences of the calc-alkaline and the boninite series. The calc-alkaline crystallization sequences have olivine, followed by plagioclase or clinopyroxene, but those of boninites have olivine followed by orthopyroxene (or clinoenstatite). A second difference forms the common persistence of olivine in calc-alkaline magmas to further evolved melt compositions than in the boninite series. Finally, igneous amphibole and biotite are exceedingly rare in boninite derivatives, and were not observed in samples of Site 786. The secondary origin for amphibole in some of the samples is the topic of a later section.

\section{Mineral-Melt Equilibria for Primitive Magmas of Site 786}

Three varieties of primitive magma, all boninitic, were chemically distinguished at Site 786 (i.e., low-Ca, intermediate-Ca, and high-Ca boninite, or LCB, ICB, HCB). Quench textures commonly reported in boninites are conspicuously absent in these rocks. All three boninite types have olivine as liquidus mineral. Olivine is in reaction relation with the melt to form enstatite in LCB and ICB melts, while it stably coexists with enstatite in the HCBs. Of all boninitic samples, only the ICBs of Cooling Units 11R1 and 11R1a have crystallized to such an extent that the reaction relation of olivine with melt has fully been completed. The virtual absence from most boninites of Site 786 of olivine and orthopyroxene that deviate in $\mathrm{Mg}$ number, that have disequilibrium morphologies, or that exhibit zonation (see Figs. 2, 4, and 5) indicates that either the equilibration of these minerals with the melt is very rapid or that these magmas resided for a long time at constant physical conditions.

The $\mathrm{Kd}$ of $\mathrm{Fe} / \mathrm{Mg}$ partitioning between minerals and melt (defined as $\left.\mathrm{Kd}=\left(\mathrm{Fe}^{2+} / \mathrm{Mg}\right)_{\text {mineral }} /\left(\mathrm{Fe}^{2+} / \mathrm{Mg}\right)_{\text {mett }}\right)$ appears to have the same value for the olivine-melt and enstatite-melt equilibria, based on the identical $\mathrm{Mg}$ numbers of coexisting olivine and enstatite in primitive samples. We can calculate an $\mathrm{Fe} / \mathrm{Mg}$ partition coefficient for olivine with respect to the bulk rock and with respect to the glass composition of the sample. Two considerations need to be taken into account: (1) only the first increment of crystallization can truly be from a melt of bulk-rock composition, because crystallization changes this composition, and (2) the melt contains ferric and ferrous iron but only the total iron content is
Table 6. Chemical characteristics of the rock types.

\begin{tabular}{lcccc}
\hline & $\begin{array}{c}\mathrm{Mg} /(\mathrm{Mg}+\mathrm{Fe}) \\
(\%)\end{array}$ & $\begin{array}{c}\mathrm{Ca} /(\mathrm{Ca}+\mathrm{Na}) \\
(\%)\end{array}$ & $\begin{array}{c}\mathrm{CaO} \\
(\mathrm{wt} \%)\end{array}$ & $\begin{array}{c}\mathrm{SiO}_{2} \\
(\mathrm{wt} \%)\end{array}$ \\
\hline $\begin{array}{l}\text { Low-Ca boninite } \\
\begin{array}{c}\text { Intermediate-Ca } \\
\text { boninite }(\approx 41 \mathrm{Ma})\end{array}\end{array}$ & $75.8 \pm 1.2$ & $47 \pm 3$ & $4.5-5.5$ & $54-59$ \\
$\begin{array}{c}\text { Intermediate-Ca } \\
\text { boninite (young) }\end{array}$ & $72 \pm 5$ & $62 \pm 5$ & $5.9-8.5$ & $52-61$ \\
$\begin{array}{c}\text { High-Ca boninite } \\
\begin{array}{c}\text { Low-Ca } \\
\text { bronzite andesite }\end{array}\end{array}$ & $71.5 \pm 2.5$ & $72 \pm 5$ & $9.5-13$ & $51-56$ \\
$\begin{array}{c}\text { Intermediate-Ca } \\
\text { bronzite andesite }\end{array}$ & $47-71$ & $35-47$ & $3.5-6.0$ & $60-64$ \\
$\begin{array}{c}\text { Andesite-dacite } \\
\text { Rhyolite }\end{array}$ & $20-53$ & $30-62$ & $5.6-8.7$ & $57-63$ \\
\hline & $5-40$ & $12-26$ & $0.8-3.0$ & $71-76$ \\
\hline
\end{tabular}

knownfromanalysis. Anapparentpartitioning coefficientKd', when not distinguishing $\mathrm{Fe}^{2+}$ and $\mathrm{Fe}^{3+}$, is calculated as: $\mathrm{Kd}^{\prime}=$ $\left(\mathrm{Fe}^{2+} / \mathrm{Mg}\right)_{\text {mineral }} /\left(\mathrm{Fe}_{\text {total }} / \mathrm{Mg}\right)_{\text {melt. }}$.

Roeder and Emslie (1970) experimentally determined the partition coefficient for the olivine-melt equilibrium to be $\mathrm{Kd}=0.3$. Using this value, equilibrium olivine compositions can be calculated for a melt of boninite bulk-rock composition. The ICB Samples 125-786A$13 \mathrm{X}-\mathrm{CC}$ and $125-786 \mathrm{~B}-37 \mathrm{R}-3,13-15 \mathrm{~cm}$, from the sill, and the LCB Sample 125-786B-59R-3, 84-91 cm, have calculated equilibrium olivine of forsterite $91.4,87.2$, and 91.7 , respectively. If we assume the presence of ferric iron in the bulk rock, these Mg numbers would be even higher. Compared with other boninites, Site 786 samples lack such extremely magnesian phenocrysts of forsterite $>90$ despite their high bulk-rock $\mathrm{Mg}$ numbers. This indicates that these high $\mathrm{Mg}$ numbers are caused by the accumulation of magnesian minerals, or that the Site 786 melts cooled further below their liquidus temperature before eruption than is common for boninites.

The olivine-glass equilibrium can be used to estimate the ferric and ferrous iron contents, or oxidation state, of the melt. ICB Sample 125-786A-13X-CC has a $\mathrm{Kd}^{\prime}=0.26$, and ICB Sample $125-786 \mathrm{~B}-37 \mathrm{R}-3,31-35 \mathrm{~cm}$, has a $\mathrm{Kd}^{\prime}=0.19-0.21$. The ratio of $\mathrm{Kd} / \mathrm{Kd}^{\prime}$, using the Roeder and Emslie (1970) value of $\mathrm{Kd}=0.30$, gives the value for $\mathrm{Fe}^{2+} / \mathrm{Fe}_{\text {total }}$ for the melt. The ferrous iron fraction of Sample 125-786A-13X-CC is $84 \%$ and that of Sample $125-786 \mathrm{~B}-37 \mathrm{R}-3,31-35 \mathrm{~cm}$, is $63 \%-70 \%$.

The three types of boninite may be conveniently compared to similar, experimentally studied compositions (van der Laan et al., 1989). The experimentally studied samples are (1) a high-Ca boninite from Cyprus very similar in composition to the Site $786 \mathrm{HCB},(2)$ an intermediate-Ca boninite from the Bonin Islands, and (3) a low-Ca boninite from Cape Vogel. The latter two are lower in $\mathrm{Mg}$ number and higher in $\mathrm{SiO}_{2}$ than the Site 786 samples. The phase equilibria for Site 786 boninites are thought to be closely approximated by the relationships depicted for HCB and for LCB in Figure 17.

Primary boninites have an olivine stability field near their watersaturated liquidus. This olivine field extends to temperatures further below the liquidus in high- $\mathrm{Ca}$ (and low-Si) boninite than in low-Ca (and high-Si) boninite (van der Laan, 1987). This is borne out by the phase assemblages for boninites of Site 786 and is schematically depicted in Figure 17. Primary boninites of super-liquidus temperatures will necessarily pass through an olivine crystallization field upon cooling or water loss. With further cooling or water loss, olivine 


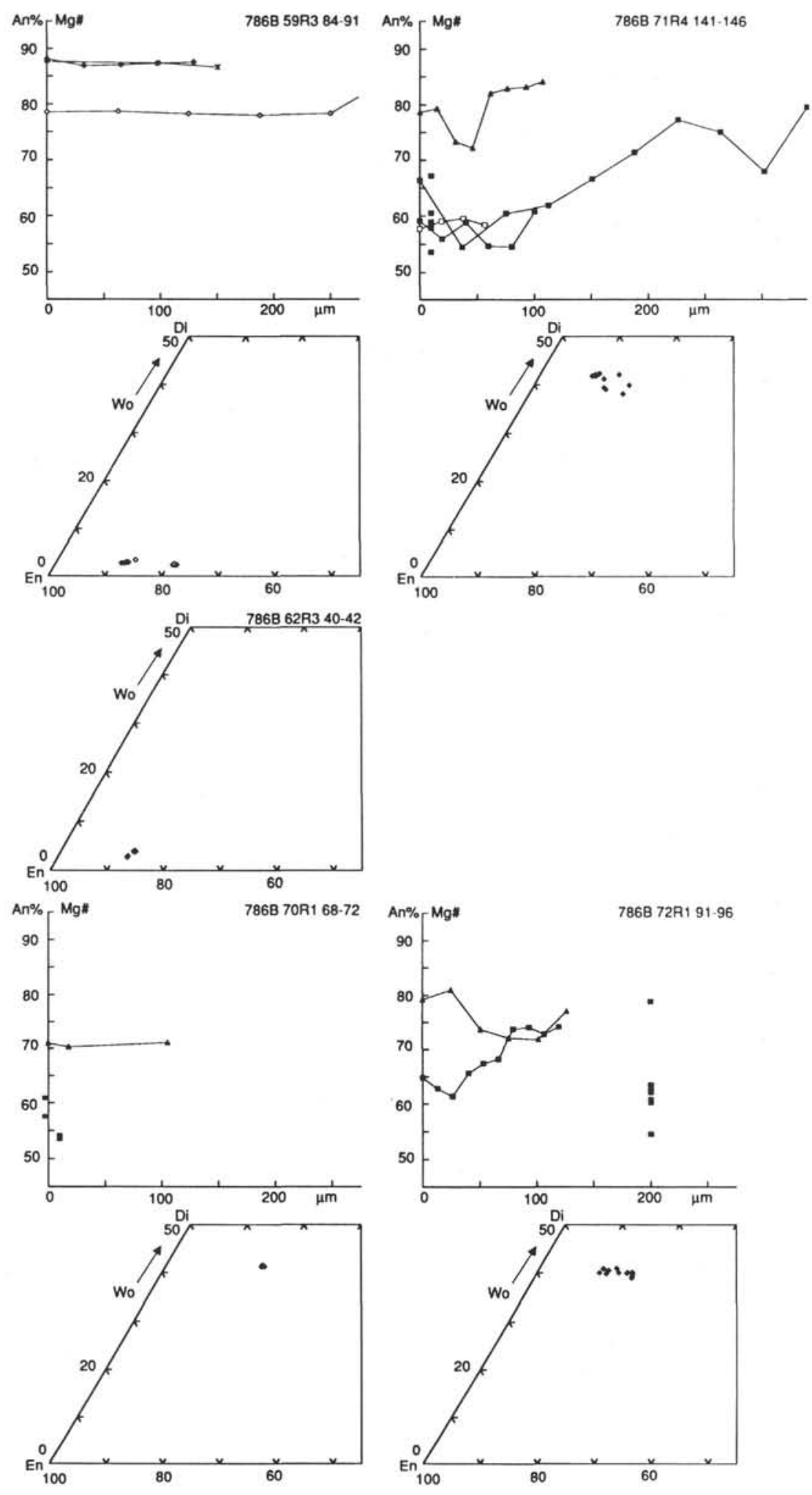

Figure 2. Mineral compositions and zonation patterns for low-Ca boninite and low-Ca bronzite andesite. For each sample, the top diagram with orthogonal axes gives Mg\# and An\% vs. distance (DI), and in the lower diagram mafic mineral compositions are projected in the pyroxene quadrilateral. Key to symbols: Open symbols $=$ anhedral, resorbed phases; closed symbols $=$ equilibrium, euhedral minerals. In the zonation diagram, plagioclase is represented by squares and horizontal bars, clinopyroxene by triangles, orthopyroxene by diamonds, and olivine by snowflakes. Crystal rims are at $0 \mathrm{~mm}$; symbols at negative distances (i.e., to the left of the vertical axis) are groundmass. In the pyroxene quadrilateral segment, olivines are represented by snowflakes, individual pyroxenes by diamonds (small diamonds for groundmass), aggregate pyroxenes by triangles, and " $\mathrm{X}$ " is glass. $\mathrm{En}=$ enstatite, Wo = wollastonite, and $\mathrm{Di}=$ diopside. 


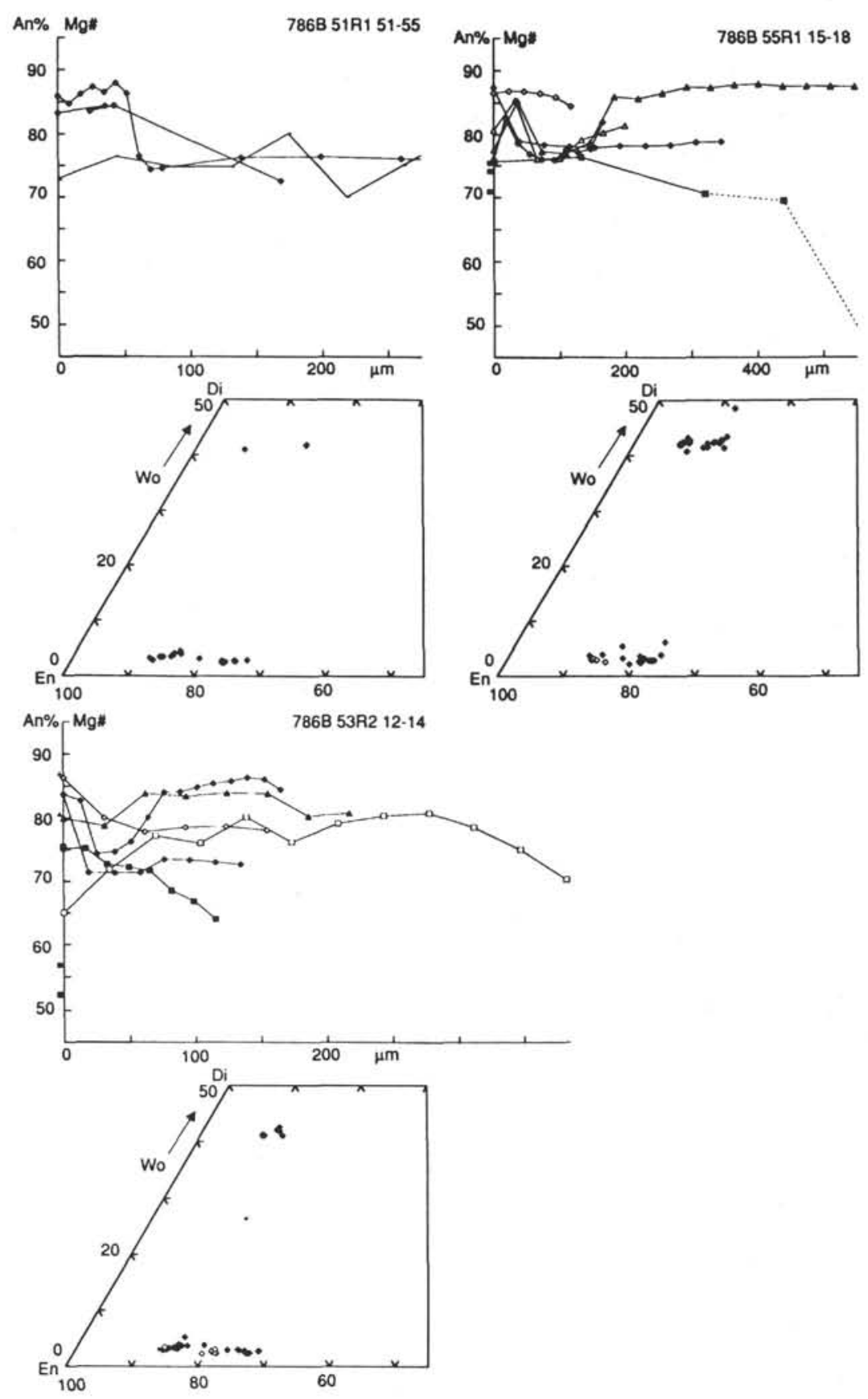

Figure 3. Mineral compositions for intermediate-Ca boninites of the edifice-building volcanic episode. See Figure 2 caption for key to symbols.

will be resorbed and orthopyroxene will crystallize. The measured water contents for ICB of 1.4 to $1.7 \mathrm{wt} \%$ (Newman and van der Laan, this volume), which are in close agreement with the value of Dobson and O'Neil (1987) for boninite glasses of Chichi-Jima of 1.6 to 1.7 wt $\%$, undersaturate the melt at $1 \mathrm{kbar}$. At the pressure of eruption, however, the melts were water-saturated and the vesiculation indicates loss of water. The measured water contents must thus be considered minimum values.

The phase diagrams can be used to estimate the crystallization conditions of the boninites of Site 786. The highest magmatic temperature for a recovered sample from Site 786 is represented by the ICB dike/sill in Core 125-786B-44R, which contains only phenocrysts of olivine. The temperature of emplacement depends on the water content of this magma but could be as high as $1260^{\circ} \mathrm{C}$. Based on the phase diagram for LCB, samples such as those from Core 786B-56R can have coexisting olivine and orthopyroxene at 1 kbar between $1260^{\circ}$ and $1230^{\circ} \mathrm{C}$ with $2 \mathrm{wt} \%$ water. Olivine will be in reaction relation with the melt to form orthopyroxene over the largest part of this temperature interval. Olivine crystallization will never result in LCBs at pressures above $2 \mathrm{kbar}$ for low water content. In principle, boninite samples bearing only orthopyroxene could have crystallized at higher pressures, but the common presence of olivine inclusions suggests that these melts crystallized at low pressure as well and equilibrated at temperatures below $1230^{\circ} \mathrm{C}$.

For the HCBs a greater temperature-pressure window exists in which olivine and orthopyroxene can coexist. Favorable conditions 

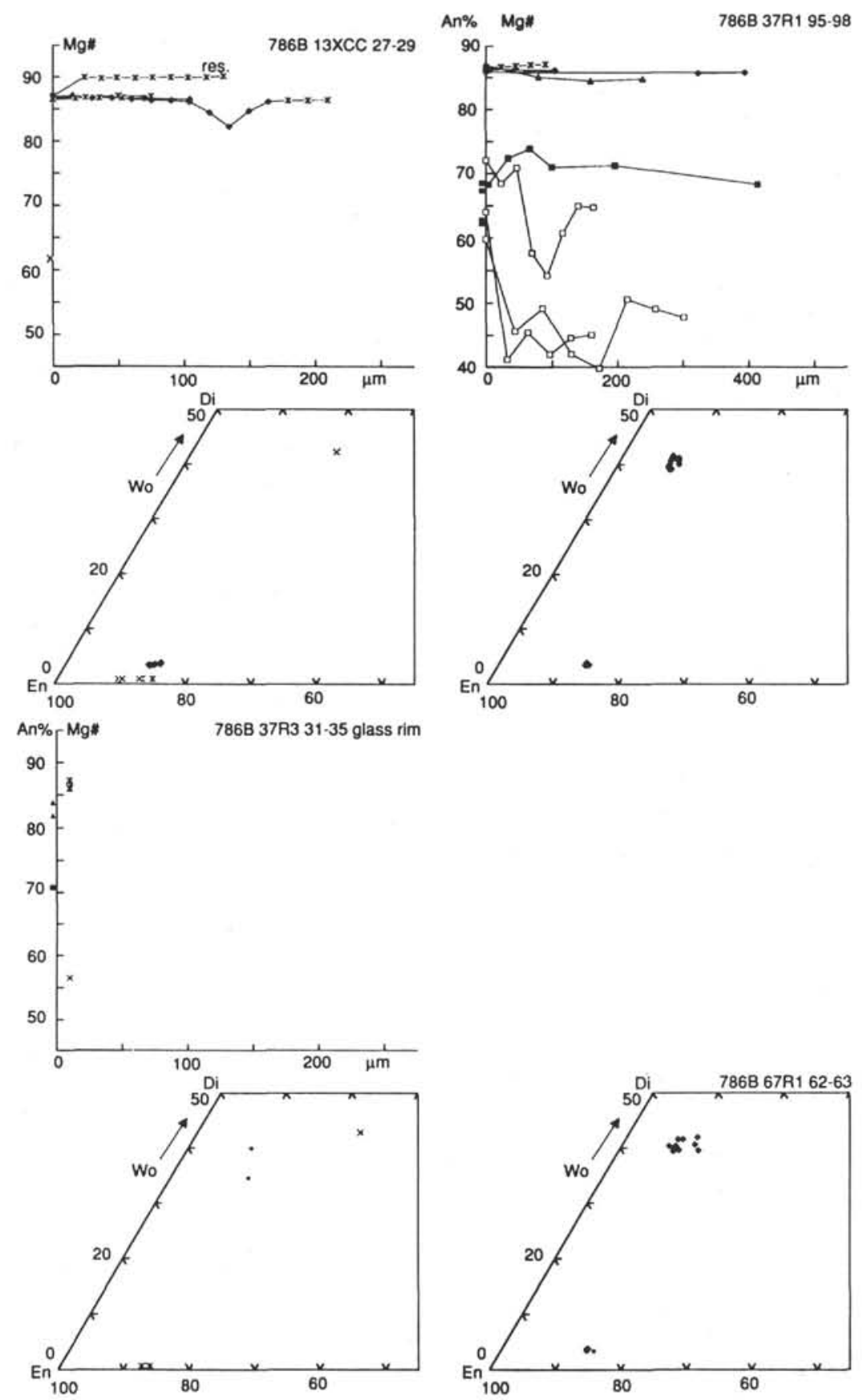

Figure 4. Mineral compositions for intermediate-Ca boninite dikes of the young volcanic episodes. See Figure 2 caption for key to symbols.

are at $1 \mathrm{kbar}$, with $1 \mathrm{wt} \%$ water, between $1250^{\circ}$ and $1200^{\circ} \mathrm{C}$, and with $2 \mathrm{wt} \%$ water, approximately between $1240^{\circ}$ and $1160^{\circ} \mathrm{C}$. In contrast to the conditions for LCBs, olivine and orthopyroxene can coexist in high-Ca boninite melt at $2.5 \mathrm{kbar}$ for low water content (Fig. 17).

Boninites that contain augite and/or plagioclase of euhedral shape have crystallized at much lower temperatures. The "augite-in" and "plagioclase-in" boundaries were not encountered in the experiments of van der Laan (1987) in a temperature interval of up to $100^{\circ} \mathrm{C}$ below the liquidus. It should be noted that the boninite samples that bear these minerals have crystallized to a much greater extent (see Appendix in back pocket). For example, the plagioclase- and augite-bearing ICBs of Core 125-786B-55R contain $30 \%$ of crystals and the groundmass glass is rhyolitic with $70.8 \mathrm{wt} \% \mathrm{SiO}_{2}$ (Newman and van der Laan, this volume). Considering the diversity of phenocryst assemblages and the large variation in degree of crystallization, we conclude that boninite magmas at Site $786 \mathrm{~B}$ were emplaced with temperatures ranging from $1260^{\circ} \mathrm{C}$ to below $1100^{\circ} \mathrm{C}$.

\section{Mineral Melt Equilibria for Evolved Magmas}

Composite isobaric rock-water phase diagrams were generated for boninitic andesite and boninitic rhyolite at 1 and $2.5 \mathrm{kbar}$. These must be considered only approximate, but are certainly valid for some compositions. There are no experimental data for low-alkali systems 
at low pressures. Instead, the phase diagrams of Figure 18 were constructed on the basis of observations of the Site 786 samples and by use of experimental data at low pressure on crystallization in andesite-, granodiorite- and granite-water systems (Baker and Eggler, 1986; Eggler and Burnham, 1973; Green, 1982; Naney, 1983; Robertson and Wyllie, 1971; Stern et al., 1975; Wyllie et al., 1976). The phase boundaries for opaque phases have been omitted. The experimentally studied compositions are all higher in alkalies than boninitic andesite and boninitic rhyolite.

Phase equilibria for experimentally studied andesite have plagioclase on the dry liquidus, followed by orthopyroxene and clinopyroxene (augite or pigeonite) at a lower temperature, within $150^{\circ} \mathrm{C}$ below the liquidus. The more mafic andesites have an olivine crystallization window in the near-liquidus temperature range. With increasing water content, orthopyroxene appears closer to the liquidus and eventually replaces plagioclase. Amphibole crystallizes below $920^{\circ}-950^{\circ} \mathrm{C}$. Bulk compositional effects on the phase equilibria are significant, especially on the "orthopyroxene-in" and "clinopyroxene-in" reactions. Ilmenite crystallization can take place at near-liquidus temperatures, but is of little importance for the Ti-poor compositions at Site 786.

In experimental studies of granodiorite and granite compositions, at low pressures $(2 \mathrm{kbar})$ plagioclase, or orthopyroxene are the liquidus phase for all water contents (Maaløe and Wyllie, 1975; Naney, 1983). At low water contents, mafic phases appear at higher temperatures in granodiorite than in granite. Hornblende does not appear, and biotite is the crystallizing hydrous mafic mineral below $870^{\circ} \mathrm{C}$. Compared to granodiorite and granite melts, the low alkali content of boninitic rhyolite will inhibit the crystallization of biotite and alkali feldspar.

It is difficult to derive phase diagrams from our observations of mineral assemblages and water contents (Newman and van der Laan, this volume) on the natural samples. The temperature of cooling below the liquidus cannot be estimated and magmatic water contents are often reduced by vesiculation. Mineral assemblages of euhedral plagioclase and resorbed pyroxene, and of euhedral pyroxene and resorbed plagioclase, are both common for closely similar bulk compositions. This indicates that the observed assemblages do not necessarily represent equilibrium and that phase relations are very sensitive to physical parameters such as temperature, pressure, and water content.

An important feature of the composite phase diagram for boninitic andesite (Fig. 18) is the steep "plagioclase-in" boundary. Plagioclase crystallization should be very sensitive to small changes in magmatic water contents, temperature, and pressure, but kinetic factors are likely to play a role, too. In addition, the plagioclase composition itself is very dependent on these parameters (Housh and Luhr, 1991). This explains the spectacular zoning patterns, and resorption and growth textures of plagioclase, such as sieve-textured plagioclase of uniform composition (oversaturation) and the extreme resorption textures of plagioclase "ball" aggregates in the mixed magmas.

The "clinopyroxene-in" boundary should lie at higher temperatures in more mafic compositions and may lie above the "plagioclasein" boundary at high water contents. Early crystallization of plagioclase should suppress the appearance of augite and favor orthopyroxene crystallization as a result of lowering the $\mathrm{Ca}$ activity. In the more calcic melts with high water contents, clinopyroxene could crystallize before orthopyroxene.

Based on phase equilibria and their interstitial melt compositions, boninitic andesites indicate temperatures from $1150^{\circ}$ to $1050^{\circ} \mathrm{C}$. This estimate is dependent on the water content of the magma and lower temperatures are likely for water-rich compositions.

The more evolved boninitic rhyolite compositions tend to crystallize homogeneous phases. This is because small amounts of plagioclase and pyroxene crystallization have a large effect on the $\mathrm{CaO}$ content or the $\mathrm{MgO}$ and $\mathrm{FeO}$ content of the melt. Small changes in temperature and water content will cause only minor oversaturation in the melt. As a consequence, only small amounts of crystallization of these phases may take place over relatively large cooling intervals, or for large amounts of water loss. Because long time periods are involved in substantial cooling, the zonation tends to be minor in phenocrysts of the boninitic rhyolites.

\section{The Significance of Amphibole in the Groundmass}

The absence of amphibole phenocrysts, yet their presence in the groundmass in andesite-dacite rocks, is highly unusual (Gill, 1981, p. 179). Boninites commonly contain quench amphibole, but these are found in more primitive melts (Cameron et al., 1979). This groundmass amphibole, having a ferro-actinolite to ferro-actinolitic hornblende composition, belongs to the calcic amphibole group (Leake, 1978), but differs from tschermakites to magnesio-hornblendes commonly reported for andesites (Jakes and White, 1972) or pargasitic hornblende in boninite (Bloomer and Hawkins, 1987). Scanning electron microscope (SEM) imaging revealed that this amphibole has high backscatter, consistent with its high iron content. Optical properties are all consistent with its analyzed composition (Tröger, 1979). The black specks on the crystal surface commonly are reported for amphibole phenocrysts and are related to low-pressure breakdown (Gill, 1981). The only other reported occurrence of amphibole in evolved boninite-derived magmas is from a rhyodacite tuff-breccia on Chichi-jima (Kuroda et al., 1988). This amphibole is also green in color but no compositional information has been published. It is unclear whether these amphiboles are magmatic or formed as an alteration product of pyroxene. Because they are often set in relatively unaltered glass, a secondary origin seems unlikely. However, considering that these glasses are extremely hydrous, locally derived water might have caused a pyroxene breakdown to form amphibole.

If the amphibole were of magmatic origin, the absence of amphibole phenocrysts should indicate that these melts were rapidly cooled from a temperature above the limit of amphibole stability, which is at $950 \pm 20^{\circ} \mathrm{C}$ for these bulk compositions (Eggler, 1972). Groundmass minerals crystallized during quenching but necessarily before the loss of large amounts of magmatic water from the melt. All amphibole-bearing samples clearly are vesiculated. A minimum water content of $3 \mathrm{wt} \%$ is required to stabilize amphibole in an andesite melt (Eggler and Burnham, 1973). Under equilibrium conditions, this requires at least 500 bar of pressure, and it implies eruption of these magmas under a $5-\mathrm{km}$ water column or, alternatively, that they solidified as dikes or sills. We are more inclined to accept a secondary origin for amphibole.

\section{Processes of Magma Differentiation}

The phase equilibria explored in the previous section apply to the shallow-level crystallization processes of Site 786 volcanic rocks. The textures and zonation patterns of minerals in these rocks potentially contain a wealth of information about magmatic processes, such as the range of magma compositions, exposure times, and thermal history they experienced. Disequilibrium mineral-melt assemblages of partially resorbed and zoned crystals attest to processes of magma mixing and differentiation.

The first igneous episode gave rise to two distinct parental magma compositions, low-Ca boninite and intermediate-Ca boninite, and two cogenetic series of bronzite andesites. Mineral zonation is common in these samples and mafic minerals may have several oscillations in composition, in which primitive $\mathrm{Mg}$ numbers recur (Figs. 6 through 9). The mineral compositions within a single sample, especially the $\mathrm{Mg}$ number of orthopyroxene, suggest that a range of melt compositions was involved in crystallization. Mineral core compositions (but also rim compositions) in the bronzite andesites can be similar to those of boninites. This indicates repeated exposure to primitive magma during the crystallization process and presumably to magma mixing and the presence of a magma chamber. 


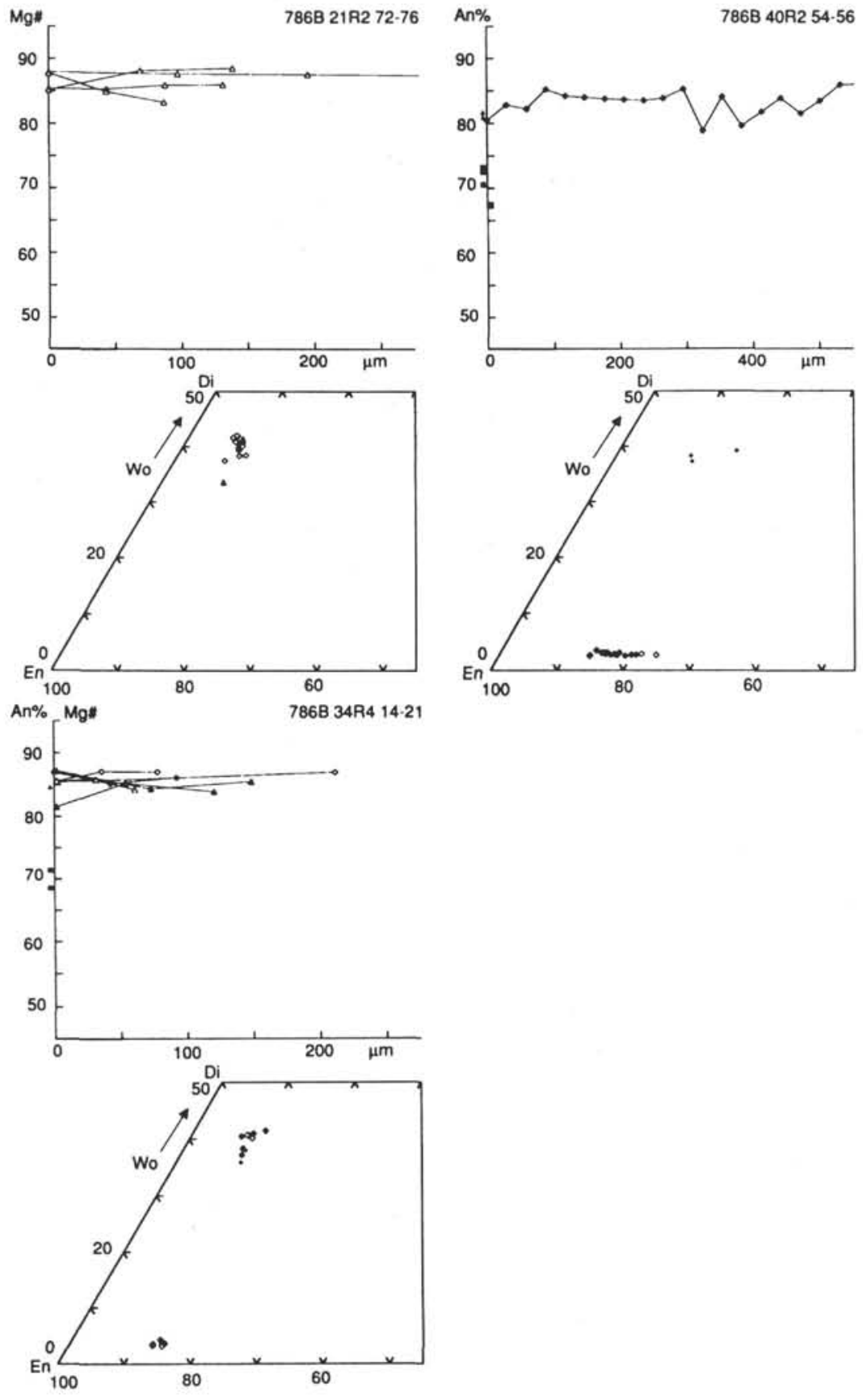

Figure 5. Mineral compositions for high-Ca boninite dikes of young volcanic episodes. See Figure 2 caption for key to symbols.

Bronzite andesites are in general very crystal-rich with $20 \%$ to $35 \%$ phenocrysts. Their high field strength and heavy rare earth element concentrations form a paradox, in that these are lower than for the parental magma (Murton et al., this volume). The bronzite andesites appear to have evolved through accumulation of minerals rather than through fractional crystallization.

The first igneous episode also gave rise to magmas of andesite, dacite, and rhyolite composition. Of these melts, the rhyolites and dacites are almost crystal free, and all are enriched in high field strength and heavy rare earth element concentrations compared to the parental boninites. These melts are likely to represent a complementary melt fraction, extracted from the bronzite andesite magmas in a filterpress-type process. Such a model for the genera- tion of evolved melts is corroborated by the interstitial glasses of dacitic and rhyolitic composition which were analyzed in some bronzite andesites (Newman and van der Laan, this volume).

The following view of the volcanic system at Site 786 emerges from our observations. In the first ( 40 to $42 \mathrm{Ma}$ ) igneous episode it comprised a shallow reservoir in which boninitic melts evolved to and mixed with a range of bronzite andesite magmas. Magmas were crystal-rich and temperatures in the magma chamber, estimated from phase equilibrium studies, in general must have been below $1150^{\circ} \mathrm{C}$. Two types of magma were erupted from this magma chamber: an evolved, crystal-poor melt of andesite to rhyolite composition (the filterpressed extract), and a crystal-rich, residual magma of bronzite andesite composition (the complimentary cumulate). Magma in the 

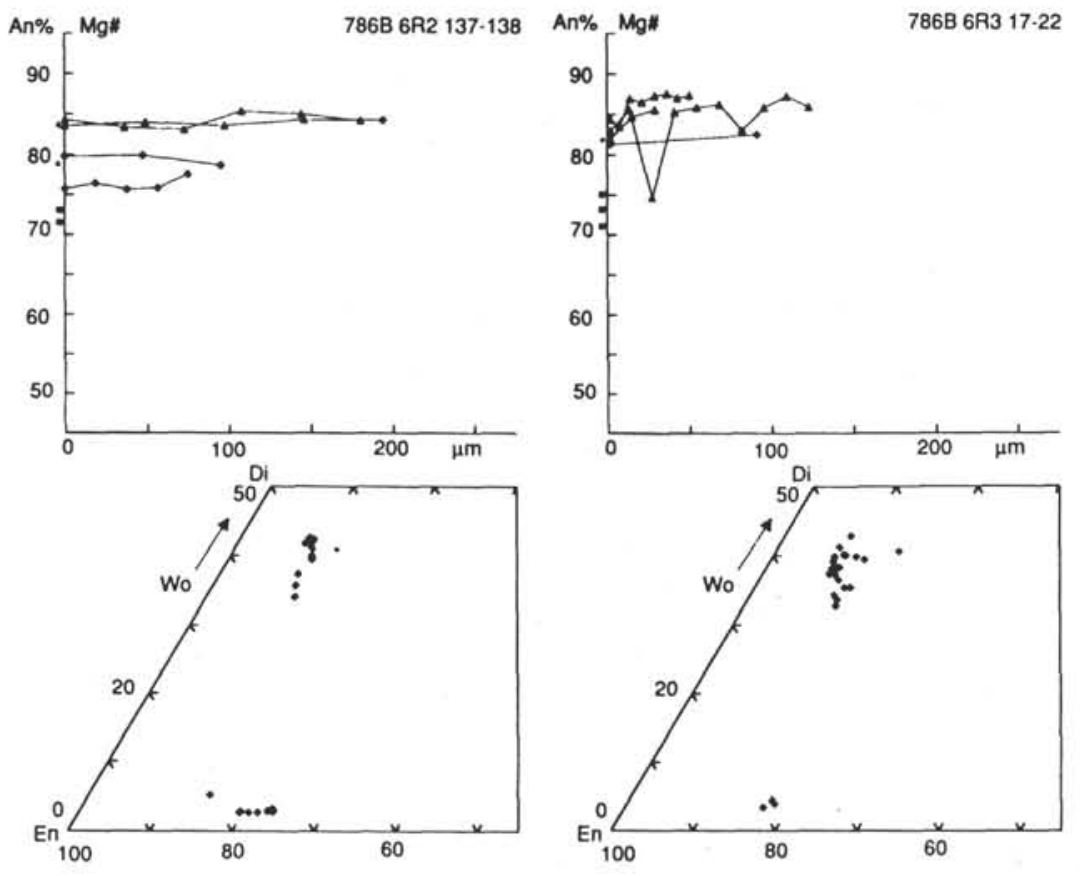

Figure 5 (continued).

volcanic system was probably processed in small batches. A low-Ca magma batch that yielded LCBs, and LCBrzAs with rhyolites, now form the lowermost strata of the sequence at Site 786. Subsequent magma batches were of ICB composition but differentiated in a similar fashion.

The younger igneous episodes produced mainly primitive boninites and few evolved melt compositions. The evolved compositions (Fig. 15) in Subunit 21 are explained by crystal settling and those of Subunit 9 are attributed to alteration. The mineral assemblages of the young boninites are unique to each dike/sill and reflect variable degrees of cooling below the liquidus temperature before emplacement. Mineral zonation and resorption is largely absent (Figs. 4,5, and 15). The observations indicate that these magmas did not experience magma chamber processes but were produced as individual melt batches. In these later igneous episodes no magma chamber was established and primitive boninites were directly emplaced.

\section{SUMMARY}

The igneous basement of Site 786 comprises a volcanic sequence of primitive boninites and the derived evolved magmas, bronzite andesites, andesites, dacites, and rhyolites (Arculus et al., this volume). Hyaloclastic textures attest to the submarine character of volcanism for many of the cooling units. Radiometric dates (Mitchell et al., this volume) indicate multiple magmatic episodes. Three primitive magmas were recognized (Arculus et al., 1991) — high-Ca, intermediate$\mathrm{Ca}$, and low-Ca boninite- but bronzite andesites dominate the lithostratigraphy. The bronzite andesites mixed with boninite melts. The sparsely-phyric andesites, dacites, and rhyolites, interspersed with the bronzite andesites, represent filterpressed melt extracts from bronzite andesite magma. Crystallization temperatures of magmas range from $1250^{\circ} \mathrm{C}$ for boninites to approximately $1000^{\circ} \mathrm{C}$ for rhyolites.

Magma differentiation took place only during the first igneous episode and parental magmas were of low-Ca and intermediate-Ca composition. Subsequent igneous events gave rise to the high-Ca composition and intermediate-Ca boninite dikes and sills of the sequence.

\section{ACKNOWLEDGMENTS}

We thank Jim Gill for his very helpful comments. This research was supported by USSAC. JAP and BJM were supported by a NERC (U.K.) ODP Special Topics research grant. SvdL acknowledges the receipt of a SOEST/HIG postdoctoral fellowship at the University of Hawaii. This is SOEST contribution no. 2671.

\section{REFERENCES}

Armstrong, J. T., 1988. Quantitative analysis of silicate and oxide materials: comparison of Monte Carlo, ZAF, and $\phi(\rho z)$ procedures. In Newbury, D. E. (Ed.), Microbeam Analyses-1988: (San Francisco Press), 239-246.

Baker, D. R., and Eggler, D. H., 1987. Compositions of anhydrous and hydrous melts coexisting with plagioclase, augite, and olivine or low-Ca pyroxene from $1 \mathrm{~atm}$ to $8 \mathrm{kbar}$ : application to the Aleutian volcanic center of Atka. Am. Mineral., 72:12-28.

Beccaluva, L., and Serri, G., 1988. Boninitic and low-Ti subduction-related lavas from intraoceanic arc-backarc systems and low- $\mathrm{Ti}$ ophiolites: a reappraisal of their petrogenesis and tectonic setting. Tectonophysics, 146:291-315.

Bloomer, S. H., and Hawkins, J. W., 1987. Petrology and geochemistry of boninite series volcanic rocks from the Mariana trench. Contrib. Mineral. Petrol., 97:361-377.

Cameron, W. E., Nisbet, E. G., and Dietrich, V. J., 1979. Boninites, komatiites and ophiolitic basalts. Nature, 280:550-553.

Crawford, A. J., Falloon, T. J., and Green, D. H., 1989. Classification, petrogenesis and tectonic setting of boninites. In Crawford, A. J. (Ed.), Boninites and Related Rocks: London (Unwin Hyman), 1-49.

Dobson, P. F., 1986. The petrogenesis of boninite: a field, petrologic, and geochemical study of the volcanic rocks of Chichi-Jima, Bonin Islands, Japan [Ph.D. dissert.]. Stanford Univ.

Dobson, P. F., and O'Neil, J. R., 1987. Stable isotope compositions and water contents of boninite series volcanic rocks from Chichi-jima, Bonin islands, Japan. Earth Planet. Sci. Lett., 82:75-86.

Duncan, R. A., and Green, D. H., 1980. Role of multistage melting in the formation of oceanic crust. Geology, 8:22-26.

Eggler, D. H., 1972. Amphibole stability in $\mathrm{H}_{2} \mathrm{O}$-undersaturated calc-alkaline melts. Earth Planet. Sci. Lett., 15:28-34. 

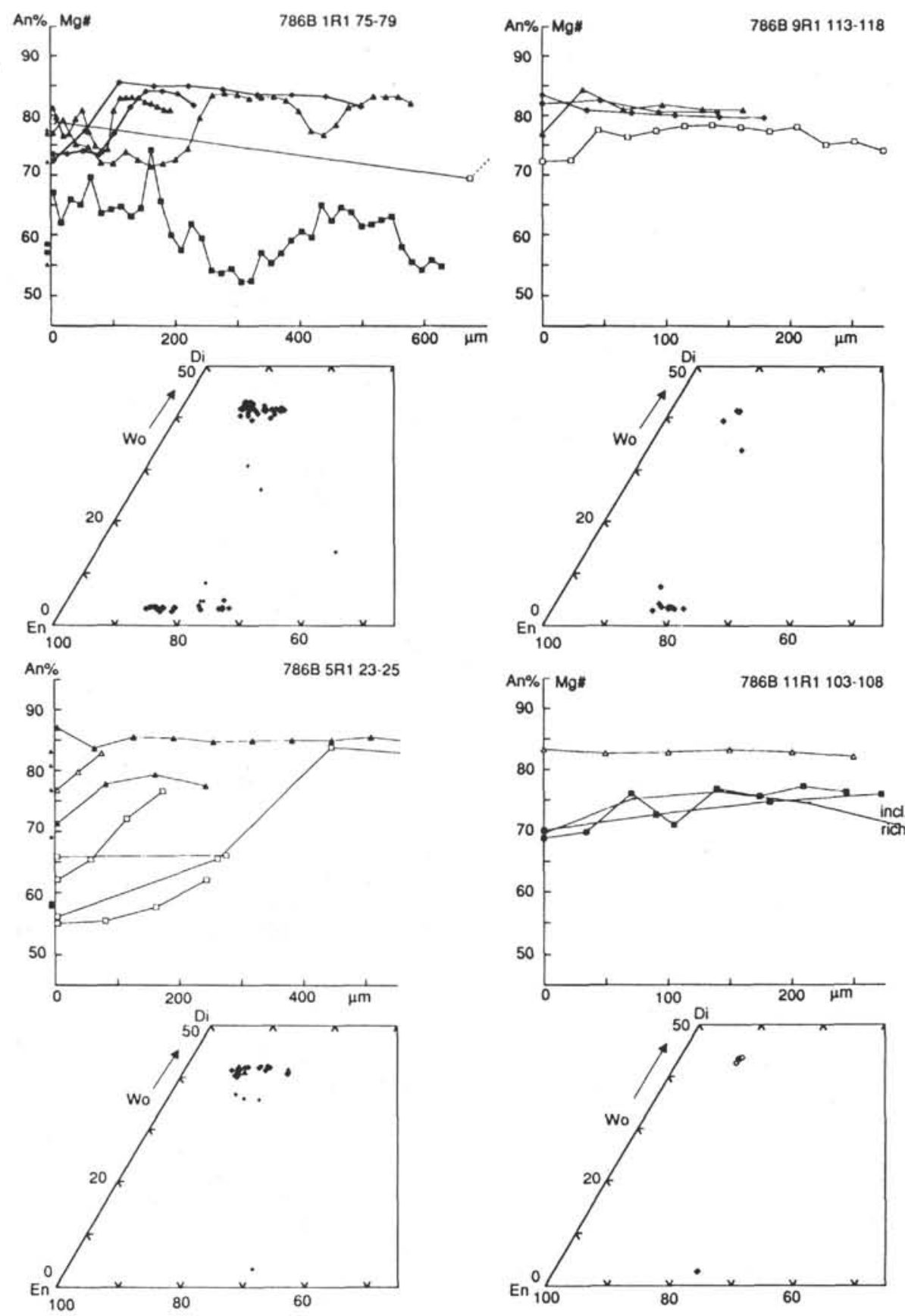

Figure 6. Mineral compositions of intermediate-Ca bronzite andesites and associated andesites of Cores 125-786B-1R through - 12R. See Figure 2 caption for key to symbols.

Eggler, D. H., and Burnham, C. W., 1973. Crystallization and fractionation trends in the system andesite- $\mathrm{H}_{2} \mathrm{O}-\mathrm{CO}_{2}-\mathrm{O}_{2}$ at pressures to $10 \mathrm{~kb}$. Geol. Soc. Am. Bull., 84:2517-2532.

Gill, J., 1981. Orogenic Andesites and Plate Tectonics: New York (Springer-Verlag). Green, T. H., 1982. Anatexis of mafic crust and high pressure crystallization of andesite. In Thorpe, R. S. (Ed.), Andesites, Orogenic Andesites, and Related Rocks: Chichester (Wiley), 465-487.

Housh, T. B., and Luhr, J. F., 1991. Plagioclase-melt equilibria in hydrous systems. Am. Mineral., 76:477-492.

Hussong, D. M., Uyeda, S., et al., 1981. Init. Repts. DSDP, 60: Washington (U.S. Govt. Printing Office).
Jakes, P., and White, A.J.R., 1972. Hornblendes from calc-alkaline volcanic rocks of island arcs and continental margins. Am. Mineral., 57:887-902.

Kuroda, N., Shiraki, K., and Urano, H., 1978. Boninite as a possible calcalkaline primary magma. Bull. Volcanol., 41:563-575.

1988. Ferropigeonite quartz dacites from Chichi-jima, Bonin Islands: latest differentiates from boninite-forming magma. Contrib. Mineral. Petrol., 100:129-138.

Leake, B. E., 1978. Nomenclature of amphiboles. Am. Mineral., 63:1023-1052. Maaløe, S., and Wyllie, P. J., 1975. Water content of a granite magma deduced from the sequence of crystallization determined experimentally with water-undersaturated conditions. Contrib. Minercl. Petrol., 52:175-191. 

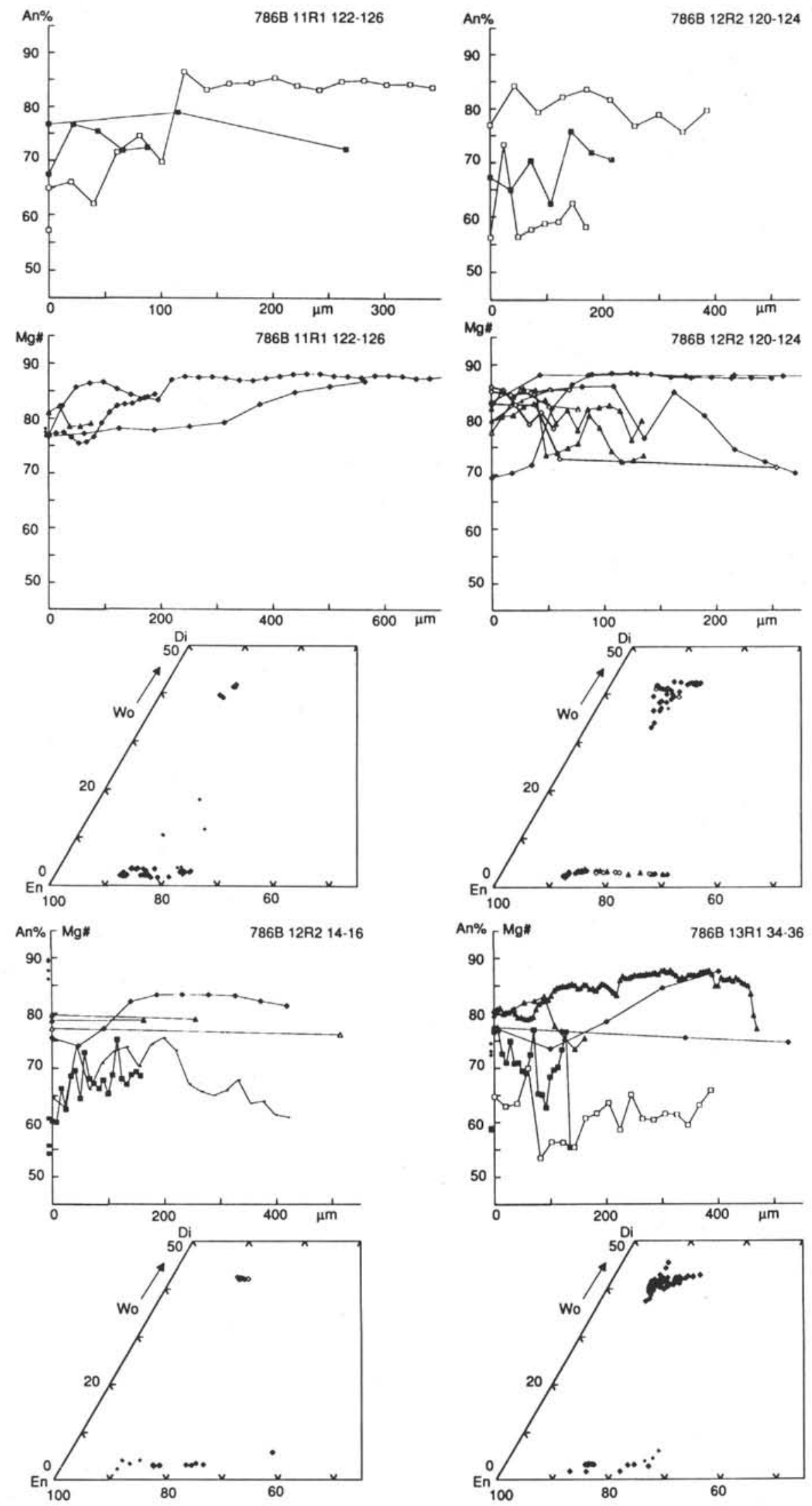

Figure 7. Mineral compositions of intermediate-Ca bronzite andesites and associated andesites of Cores 125-786B-1R through -12R. See Figure 2 caption for key to symbols. 

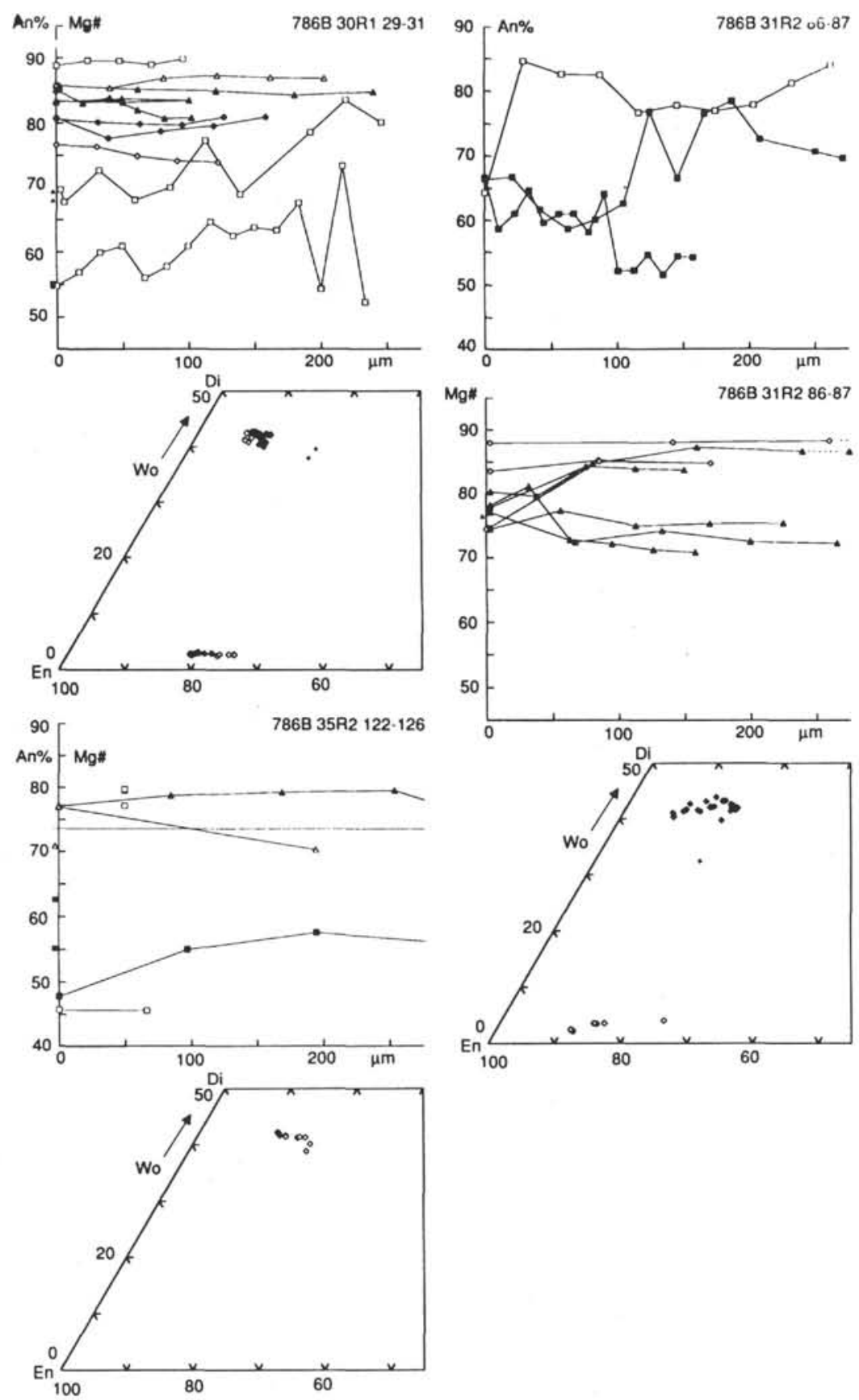

Figure 8. Mineral compositions of intermediate-Ca bronzite andesites and associated dacites of Cores 125-786B-30R through -35R. See Figure 2 caption for key to symbols.

Meijer, A., 1980. Primitive arc volcanism and a boninite series: examples from the western Pacific island arc system. In Hayes, D. E. (Ed.), Tectonic and Geologic Evolution of Southwest Asian Seas and Islands. Am. Geophys. Union, Geophys. Monogr. Ser., 23:269-282.

Naney, M. T., 1983. Phase equilibria of rock-forming ferromagnesian silicates in granitic systems. Am. J. Sci., 283:993-1033.

Natland, J. H., 1982. Crystal morphologies and pyroxene compositions in boninites and tholeiitic basalts from Deep Sea Drilling Project Holes 458 and 459B in the Mariana fore-arc region. In Hussong, D. M., Uyeda, S., et al., Init. Repts. DSDP, 60: Washington (U.S. Govt. Printing Office), 681-707.

Reagan, M. K., and Meijer, A., 1984. Geology and geochemistry of early arc-volcanic rocks from Guam. Geol. Soc. Am. Bull., 95:701-713.
Robertson, J. K., and Wyllie, P. J., 1971. Rock-water systems, with special reference to the water-deficient region. Am. J. Sci., 271:252-277.

Roeder, P. L., and Emslie, R. F., 1970. Olivine-liquid equilibrium. Contrib. Mineral. Petrol., 29:275-289.

Sakuyama, M., 1983. Petrology of arc volcanic rocks and their origin by mantle diapirs. J. Volcanol. Geotherm. Res., 18:297-320.

Stern, C. R., Huang, W. L., and Wyllie, P. J., 1975. Basalt-andesite-rhyolite$\mathrm{H}_{2} \mathrm{O}$ : crystallization intervals with excess $\mathrm{H}_{2} \mathrm{O}$ and $\mathrm{H}_{2} \mathrm{O}$-undersaturated liquidus surfaces to 35 kilobars, with implications for magma genesis. Earth Planet. Sci. Lett., 28:189-196.

Tröger, W. E., 1979. Optical Determination of Rock-forming Minerals, Part 1: Determinative Tables: Stuttgart (E. Schweizerbart'sche Verlagsbuchhandlung). 

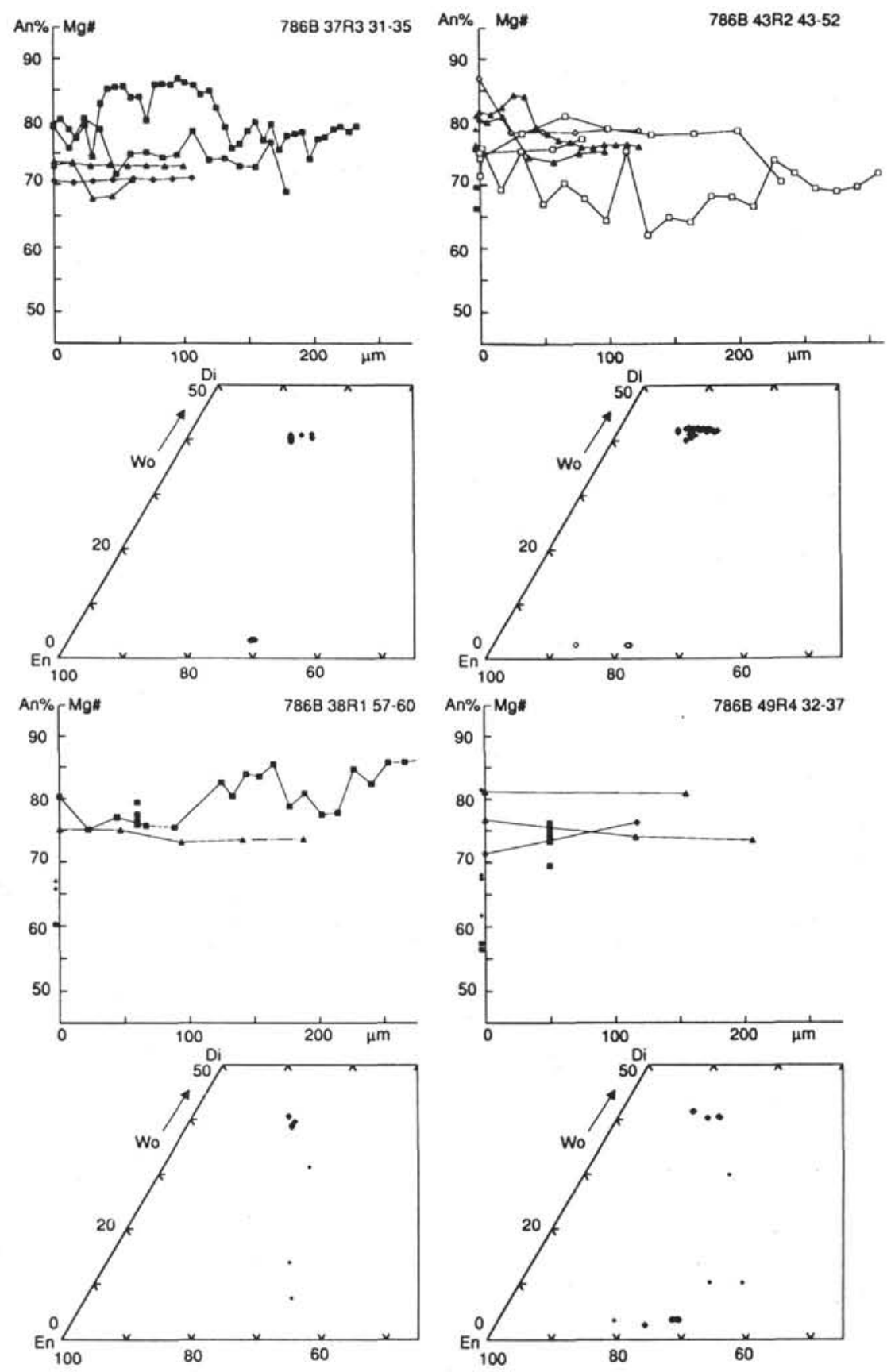

Figure 9. Mineral compositions of intermediate-Ca bronzite andesite of Cores 125-786B-37R through -49 R. See Figure 2 caption for key to symbols.

Umino, S., 1986. Magma mixing in boninite sequence of Chichi-jima, Bonin Islands. J. Volcanol. Geotherm. Res., 29:125-157.

van der Laan, S. R., 1987. An experimental study of boninite genesis [Ph.D. dissert.]. Univ. of Illinois, Chicago.

van der Laan, S. R., Flower, M.F.J., and Koster van Groos, A. F., 1989. Experimental evidence for the origin of boninites: near-liquidus phase relations to $7.5 \mathrm{kbar}$. In Crawford, A. J. (Ed.), Boninites and Related Rocks: London (Unwin Hyman), 112-147.
Wyllie, P. J., and Huang, W.-L., Stem, C. R., and Maaløe, S., 1976. Granitic magmas: possible and impossible sources, water contents, and crystallization sequences. Can. J. Earth Sci., 13:1007-1019.

Date of initial receipt: 4 October 1990

Date of acceptance: 19 August 1991

Ms 125B-139 

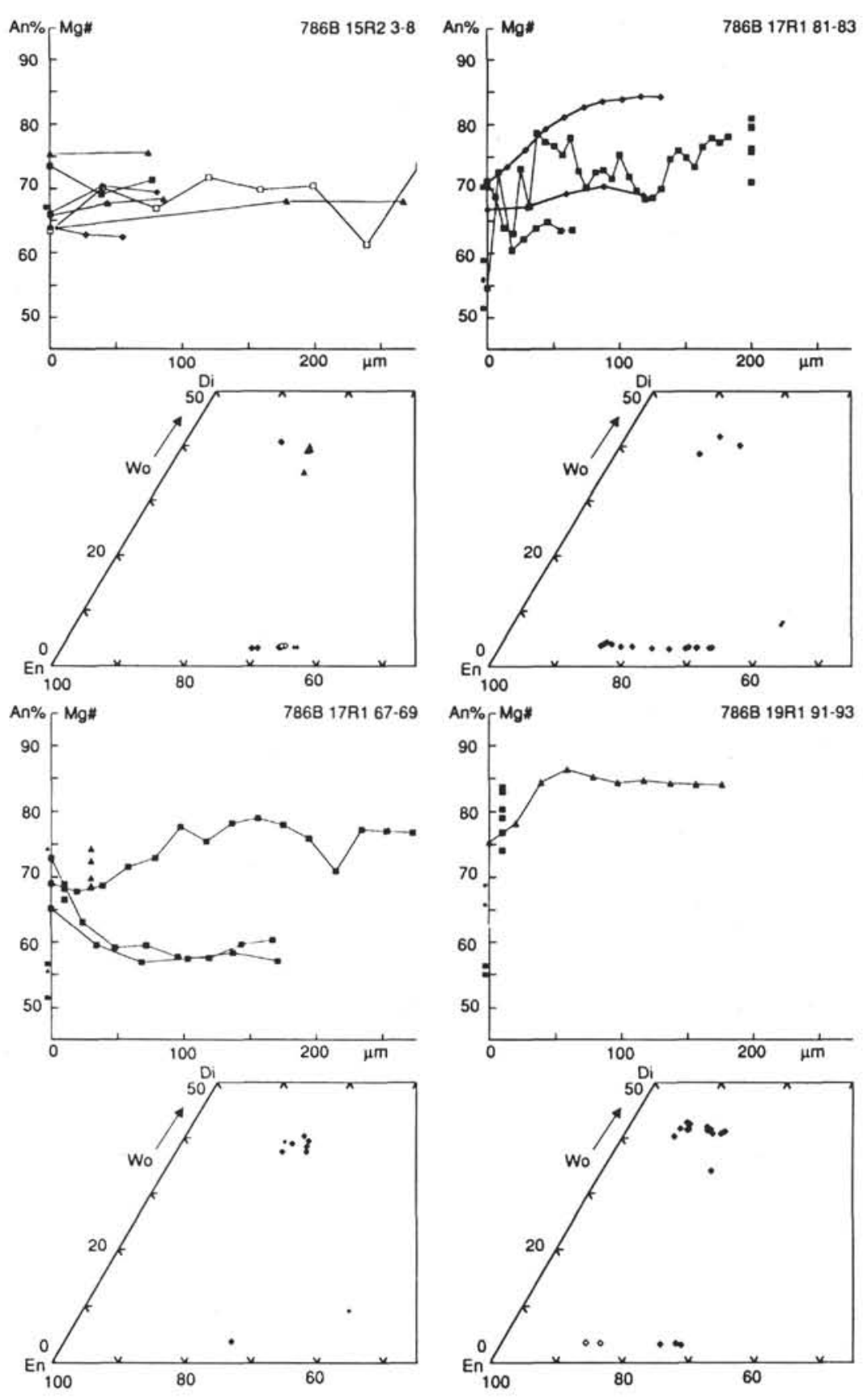

Figure 10. Mineral compositions of andesites. See Figure 2 caption for key to symbols. 

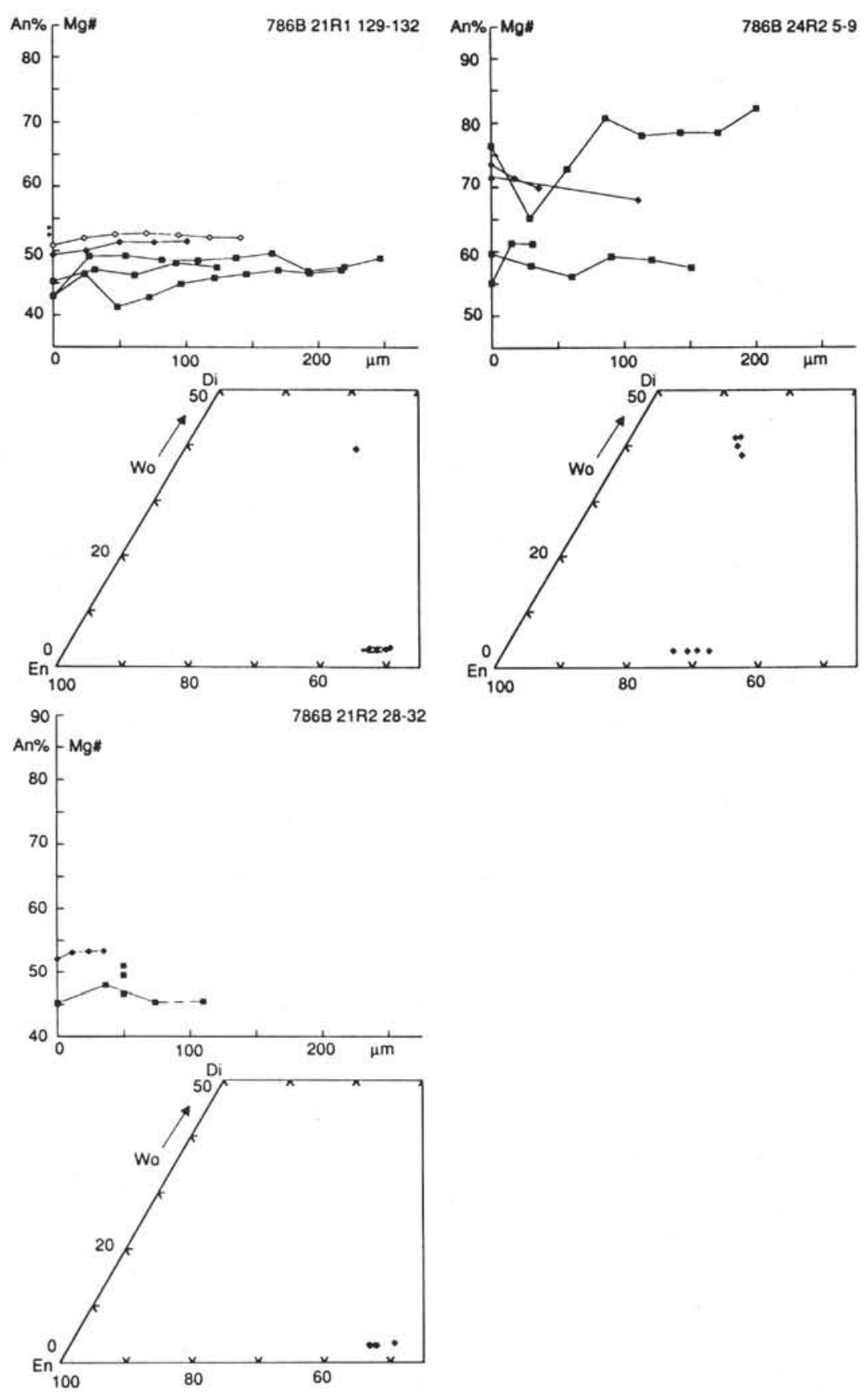

Figure 11. Mineral compositions of dacites and rhyolites. See Figure 2 caption for key to symbols. 

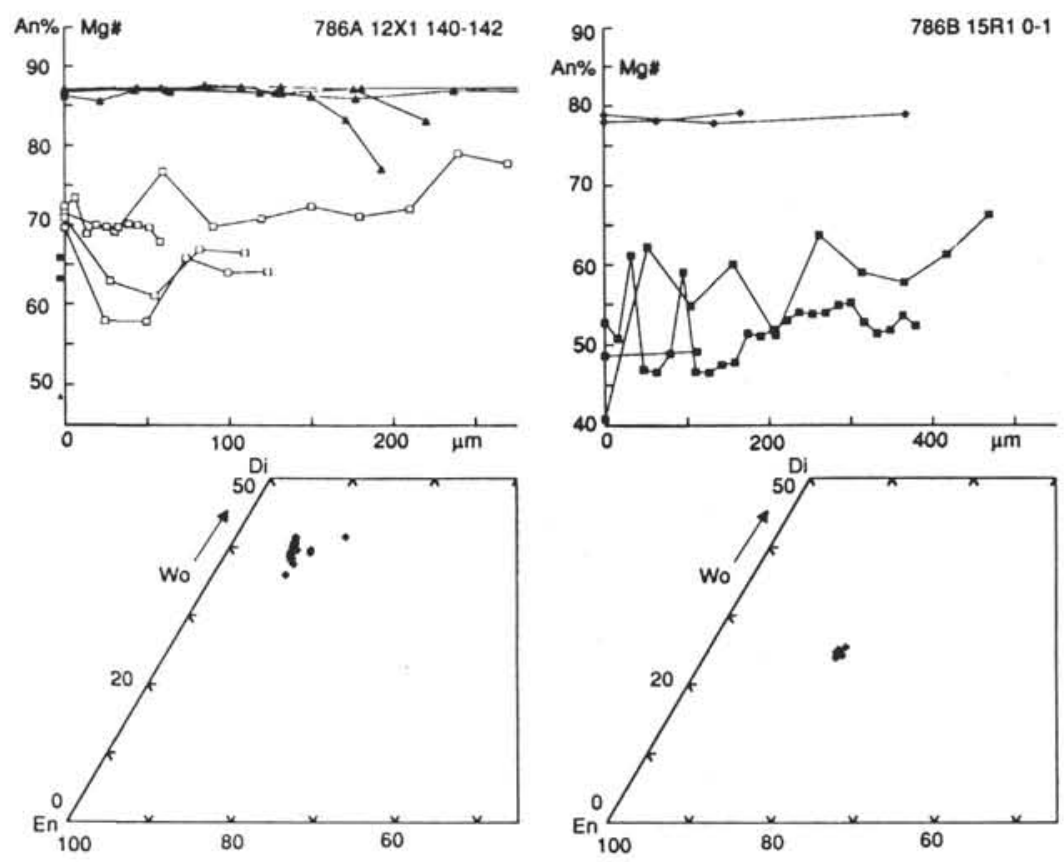

Figure 12. Mineral compositions of Sample 125-786A-12X-1, 140-142 cm, and cumulate Sample 125-786B-15R-1, 0-1 cm. See Figure 2 caption for key to symbols.

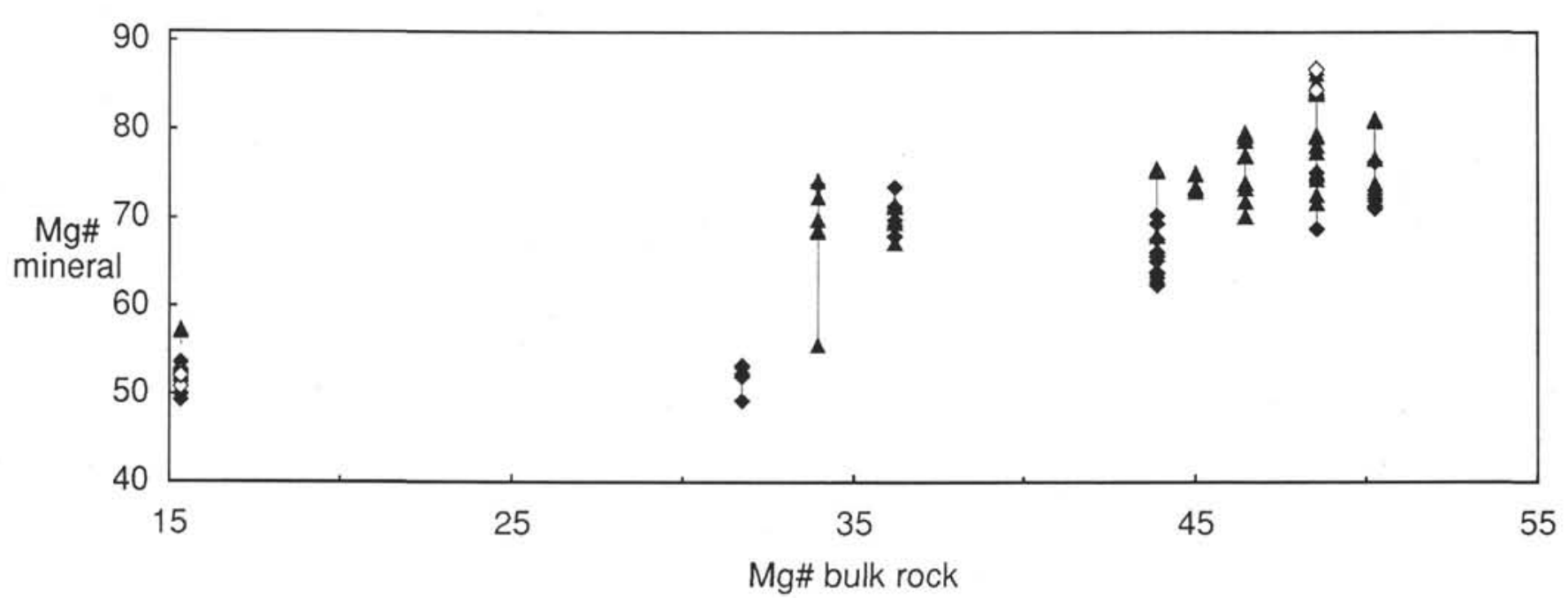

Figure 13. Phenocryst $\mathrm{Mg}$ numbers compared to bulk-rock $\mathrm{Mg}$ numbers of andesites, dacites, and rhyolites. Open symbols represent resorbed minerals; closed symbols, euhedral minerals. Diamonds represent orthopyroxene; triangles, augite. 


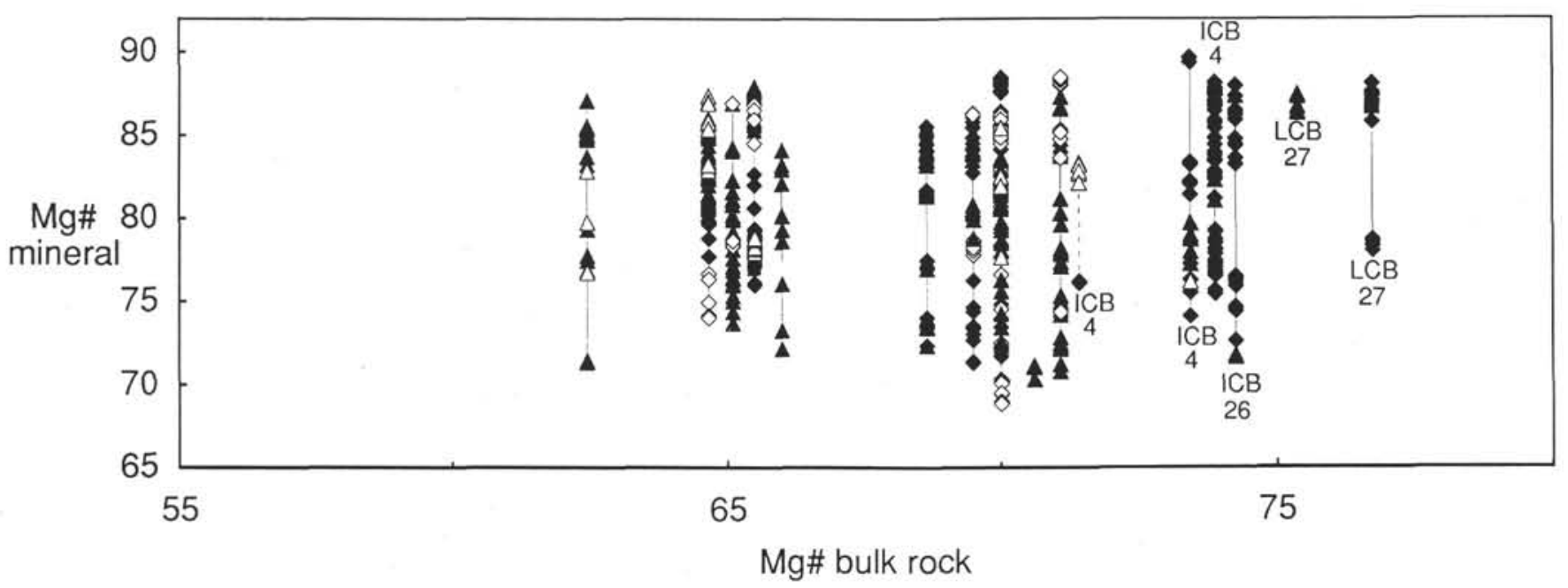

Figure 14. Phenocryst Mg numbers compared to bulk-rock Mg numbers of boninites and bronzite andesites of the edifice-building episode. $\mathrm{LCB}=$ low-Ca boninite; ICB = intermediate-Ca boninite. Numbers refer to subunits (see Fig. 1). Open symbols for resorbed minerals; closed symbols for euhedral minerals. Squares for olivine, diamonds for orthopyroxene, and triangles for augite.

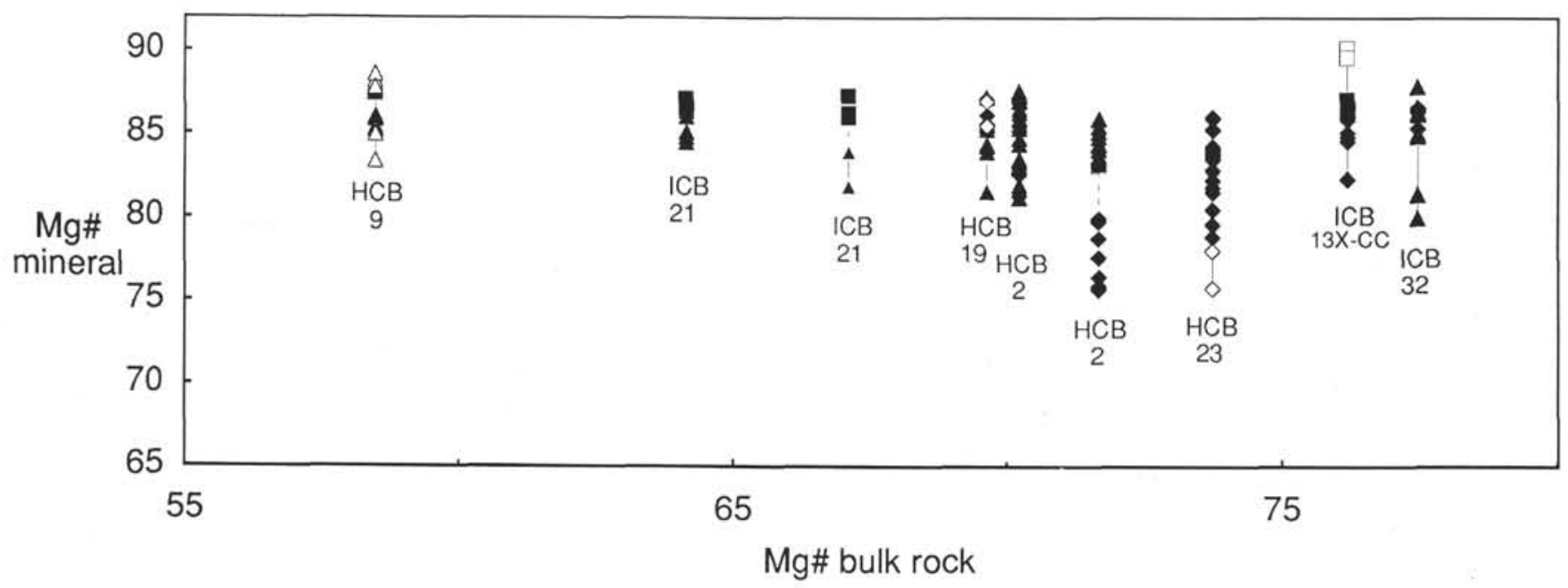

Figure 15. Phenocryst $\mathrm{Mg}$ numbers compared to bulk-rock $\mathrm{Mg}$ numbers of young boninites. $\mathrm{ICB}=$ intermediate-Ca boninite; $\mathrm{HCB}=$ high-Ca boninite. See Figure 14 caption for key to symbols. 


\section{Calc-alkaline Series}

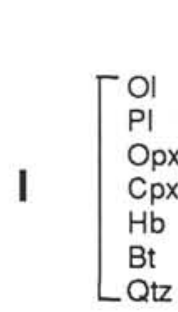

basalt andesite dacite

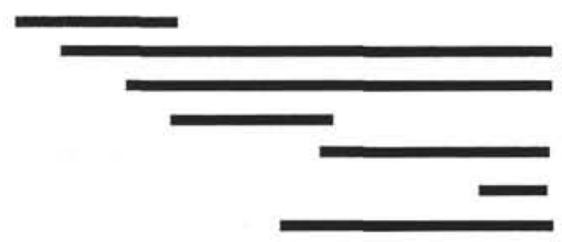

II $\quad\left[\begin{array}{l}\mathrm{OI} \\ \mathrm{PI} \\ \mathrm{Opx} \\ \mathrm{Cpx} \\ \mathrm{Hb} \\ \mathrm{Bt} \\ \mathrm{Qtz}\end{array}\right.$
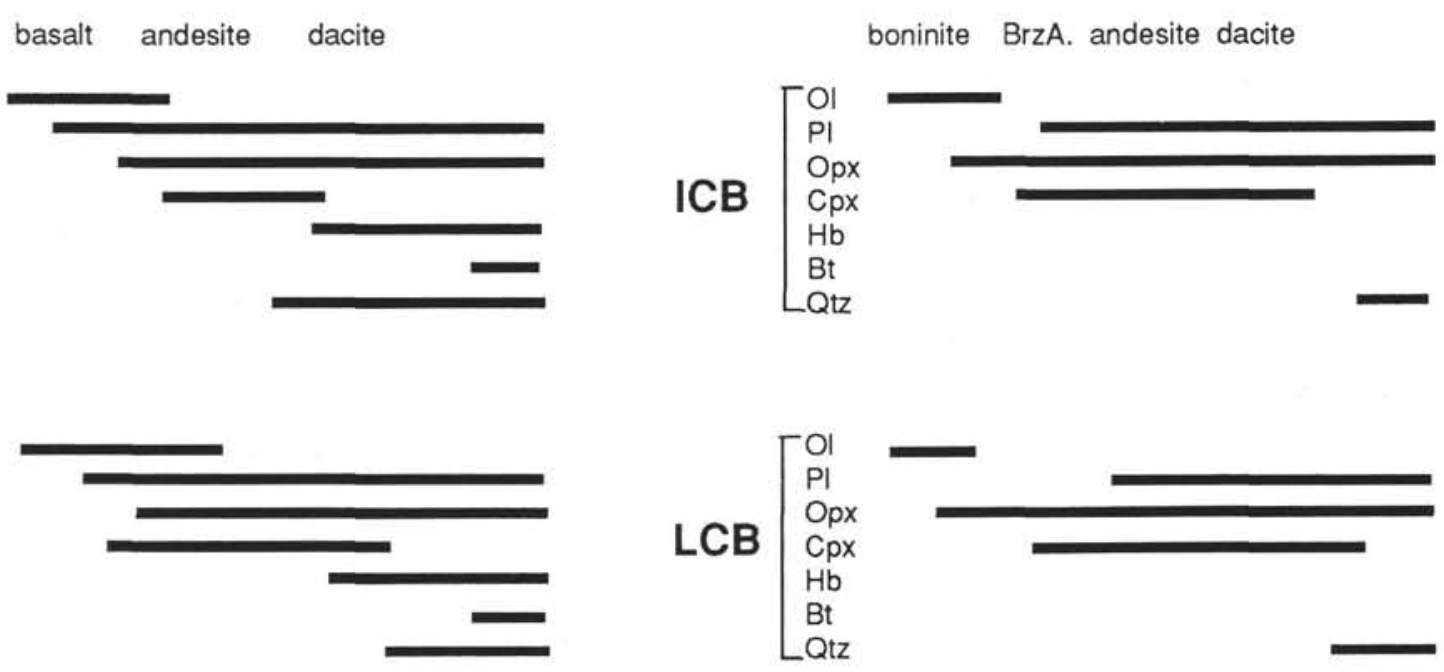

boninite BrzA. andesite dacite

\section{Boninite Series}

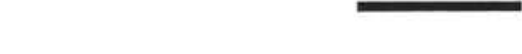

LQt

III $\quad\left[\begin{array}{l}\mathrm{Ol} \\ \mathrm{PI} \\ \mathrm{Opx} \\ \mathrm{Cpx} \\ \mathrm{Hb} \\ \mathrm{Bt} \\ \mathrm{Qtz}\end{array}\right.$
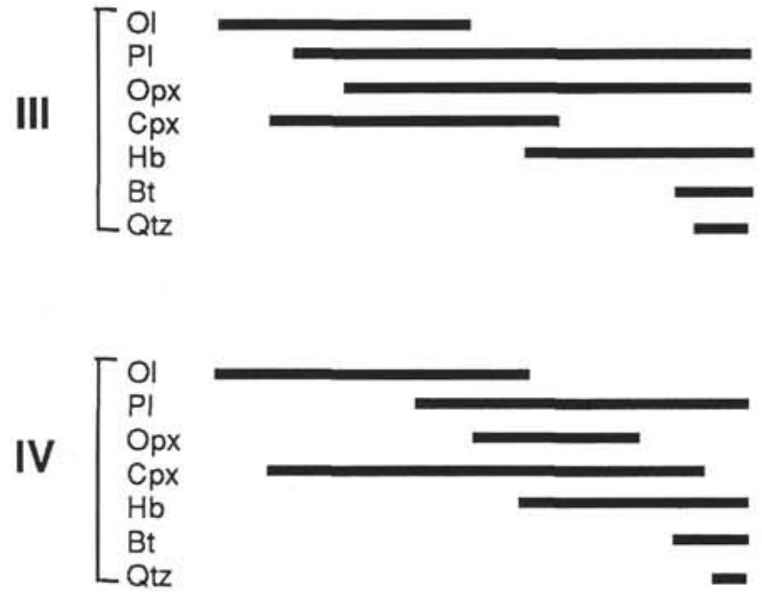

Figure 16. Generalized crystallization sequences for calc-alkaline series and boninite series magma. I = Zao, Osore-yama, II = Myoko, Kirigamine, III = Shirouma-Oike, Oshima-Oshima, Japan, and IV = Andes and Central America (after Sakuyama, 1983). ICB = Intermediate-Ca boninite series; LCB $=$ low-Ca boninite series, both at Site 786 . 


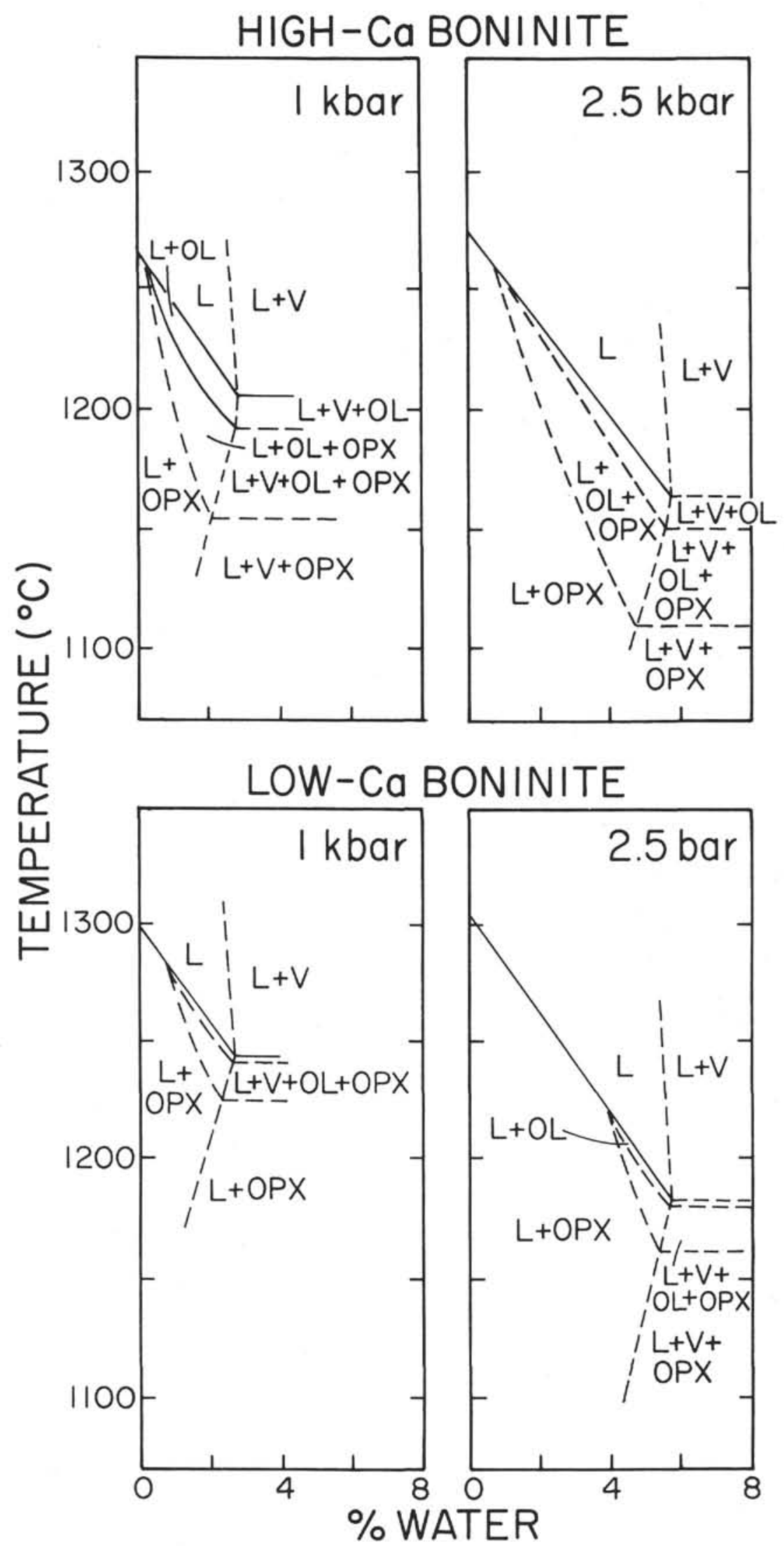

Figure 17. Isobaric rock-water phase diagrams for high-Ca and low-Ca boninite at 1 and $2.5 \mathrm{kbar}$ (after van der Laan et al., 1989). The near-liquidus olivine crystallization field is followed by an olivine resorption, orthopyroxene crystallization field at lower temperatures. Low-temperature phase equilibria are unknown and not depicted. 


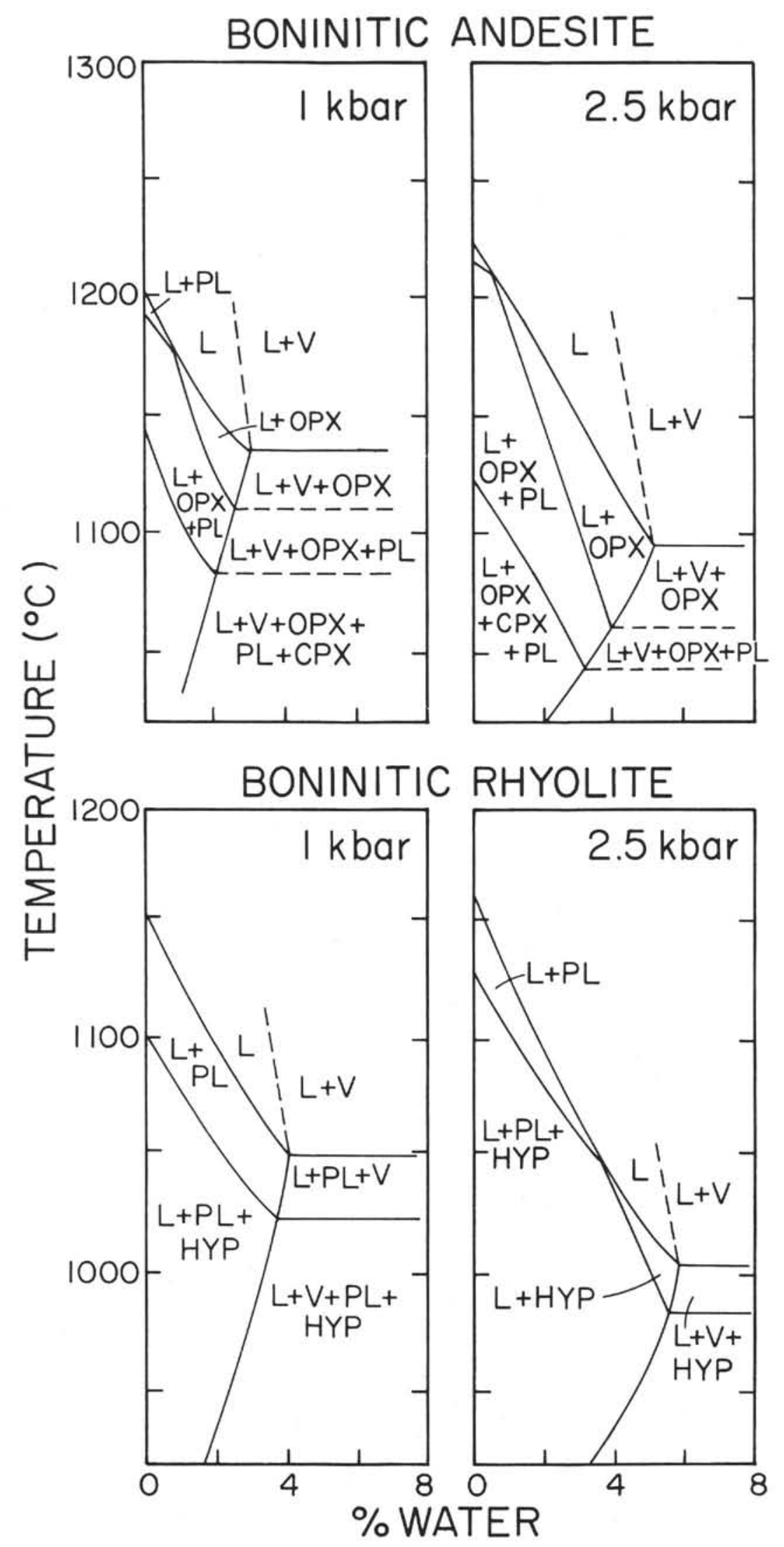

Figure 18. Composite rock-water phase diagrams for boninitic andesite and boninitic rhyolite at 1 and $2.5 \mathrm{kbar}$. The "clinopyroxene-in" reaction for the andesite melt is strongly dependent on bulk composition and may occur at higher temperature. Opaque phases have been omitted from the diagrams. 


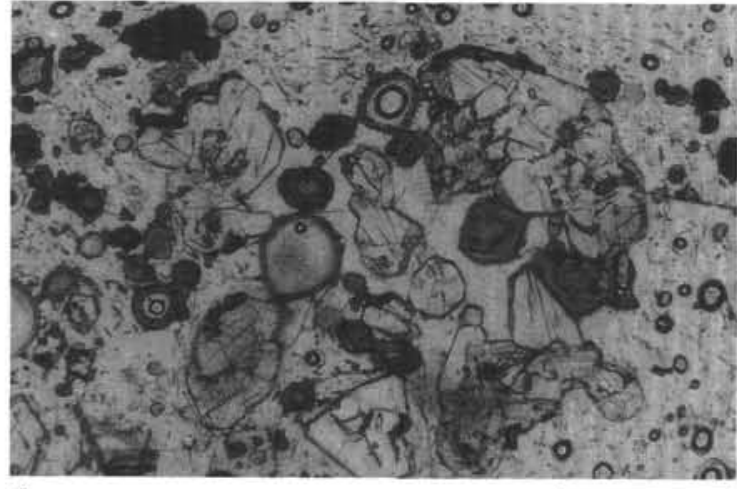

A

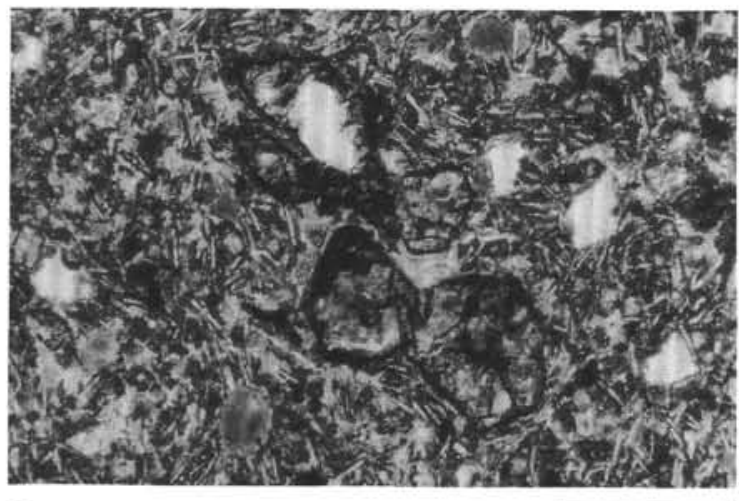

C

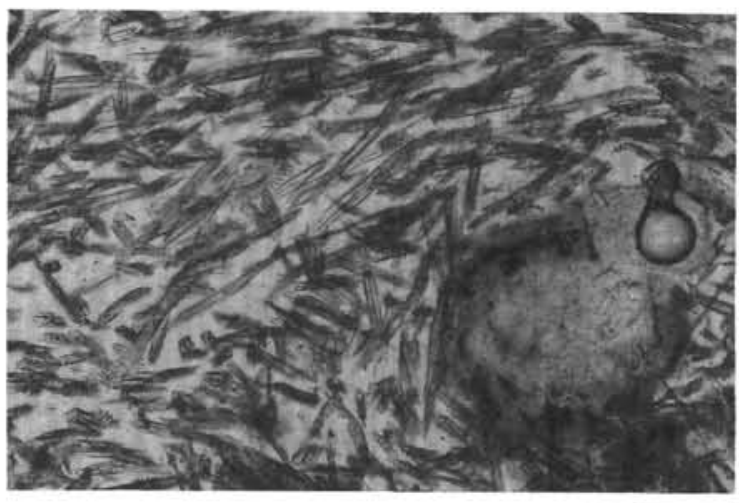

E

$0.1 \mathrm{~mm}$
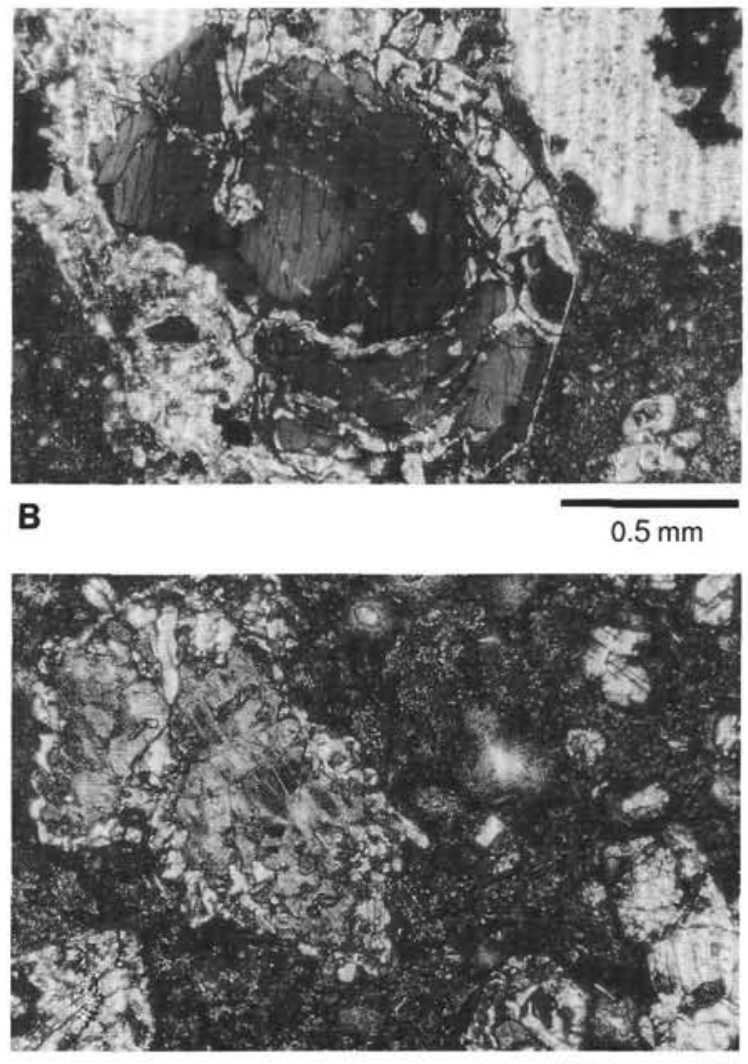

D

$0.5 \mathrm{~mm}$

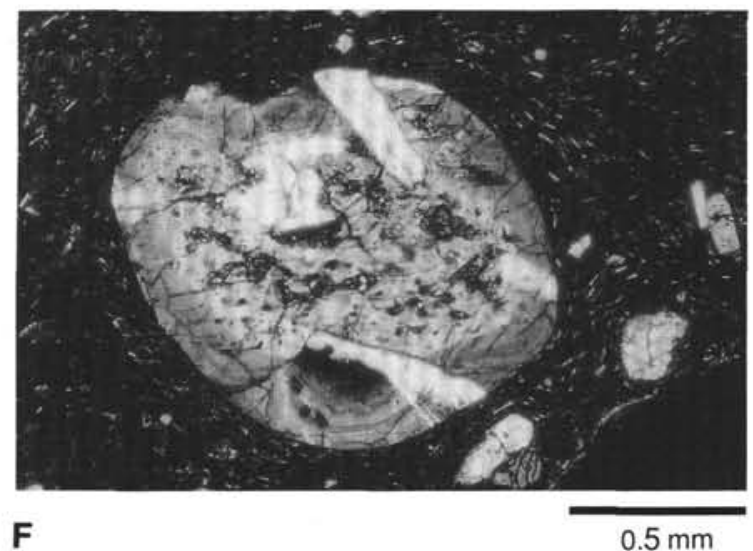

Plate 1. A. Characteristic habit of olivine phenocrysts. A skeletal olivine crystal (clear) occupies the bottom center portion. Other minerals are rounded and euhedral enstatite (gray). Groundmass is glassy and locally devitrified. (ICB Sample 125-786B-13X-CC) Plane-polarized light. B. Round olivine inclusion (bright spot in dark halo in center) in zoned, euhedral enstatite. Enstatite is partially altered. (LCB Sample 125-786B-57R-5, 49-50 cm). Crossed polars. C. Olivine relicts composed of hematite + carbonates with similar morphology as in (A), outlined by their dark rims. (HCB Sample 125-786B-40R-2, 83-90 cm) Plane-polarized light. D. Top left corner is occupied by relict olivine, now consisting of serpentine, with an orthopyroxene corona (bright white mineral grains) and with spinel inclusions (black specks in central to lower right portion of olivine). (ICB Sample 125-786B-51R-1, 51-55 cm). Plane-polarized light. E. Spinifex orthopyroxene in the groundmass of a low-Ca boninite. Minerals with fractures perpendicular to their length are thought to be clinoenstatite. (LCB Sample 125-786B-57R5, 49-50 $\mathrm{cm}$ ) Plane-polarized light. F. Plagioclase aggregate with "ball"-like shape and complex zonation as commonly found in intermediate-Ca and high-Ca boninites and bronzite andesites. (ICBrzA Sample 125-786B-3R-1, 34-44 cm). Crossed polars. 